九州大学学術情報リポジトリ

Kyushu University Institutional Repository

\title{
REVISIONAL STUDIES ON THE FAMILY LYONETIIDAE OF JAPAN (Lepidoptera)
}

Kuroko, Hiroshi

https://doi.org/10.5109/2349

出版情報 : ESAKIA. 4, pp.1-61，1964-07-30. Hikosan biological laboratory, Faculty of Agriculture, Kyushu University バージョン :

権利関係 : 


\title{
REVISIONAL STUDIES ON THE FAMILY LYONETIIDAE OF JAPAN (Lepidoptera) *
}

By

\author{
Hiroshi Kuroko
}

\section{CONTENTS}

Introduction .......................... 1

Characters of the family .................. 5

Key to the Japanese subfamilies and genera . . . . . . . . . . 6

Subfamily Bedeliiinae. ................... 7

Genus Bedellia Stainton. ..................... 7

Subfamily Bucculatricinae ................... 9

Genus Bucculatrix Zeller ....................... 9

Subfamily Lyonetiinae ................... . 13

Genus Lyonetia Huebner . . . . . . . . . . . . . . . . . . 13

Subfamily Leucopterinae .................... . . 34

Genus Microthauma Walsingham ................ 34

Genus Proleucoptera Busck ................. 36

Genus Paraleucoptera Heinrich ................. 41

Genus Leucoptera Huebner . . . . . . . . . . . . . . . . . . . . 43

Exclusion of unrelated forms.................. 45

List of the host plants of Lyonetia in the world . . . . . . . . . . . 45

List of the host plants of Leucopterinae in the world . . . . . . . . 47

Annotated list of the Japanese Erechthiidae, Oinophilidae, and

Lyonetiidae. . . . . . . . . . . . . . . . 50

References .................... 52

Explanation of plates .................. 57

\section{Introduction}

Since 1954, I have been engaging in the taxonomic and ecological studies of the Lyonetiidae. This study is a part of my contributions to the fauna of the

* Contribution Ser. 2, No. 24, Hikosan Biological Laboratory, Kyushu University, Hikosan.

Contribution Ser. 2, No. 207, Entomological Laboratory, Kyushu University, Fukuoka. 
lepidopterous leaf-miners in Japan. In this paper, strict concept to the Lyonetiidae is shown, together with some corrections to the taxonomic situations of the species which have hitherto been regarded as belonging to the Lyonetiidae, and 19 species of 7 genera including an unrecorded genus, a new subgenus, 12 new species and an unrecorded species are treated. Moreover, life histories observed are mentioned and the host plants of Lyonetia and Leucopterinae hitherto recorded in the world are enumerated.

Very little has been done on the study of Microlepidoptera and our knowledge on the group has remained fragmentary in our country. As to the Lyonetiidae, the first species concerned in Japan was Lyonetia clerkella Linnaeus. Sasaki (1903) recorded the life-history of this species without giving any specific name. In 1905, he reported this species again as a species of Tischeria (?). Later, Kuwana and Takachiho (1911) identified this species with Lyonetia clcrkella Linné and recorded the egg, larva, pupa, and adult. In 1918, the study on the life-history of this species was published by Harukawa and Yagi, but they did not give the specifie name, because they thought this species differed in several points from Lyonetia clerkella Linné. It might have been a conscientious treatment, for at that time there had been neither exchange of specimens nor comparison of the genitalia.

Lyonetia prunifoliellamalinella (Matsumura) was next described from our country. Matsumura (1906) reported for the first time this species under the name of Lithocolletis malivorella Matsumura which was placed under Gracilaridae, together with a list of its host plants (without giving any figure and description). He illustrated again the same species under the name of Lithocolletes (sic) malinella Matsumura in 1907, Lithocolletis malivorella in 1900 and 1920, and in his great work " 6000 Ill. Ins. Jap." published in 1931 he illustrated Lyoneta (sic) malivorella and $L$. (sic) ringoniella and in the following year assigned those as new species. Both of these, however, are seasonal forms of the same species. Issiki (1932) first reported Lyonetia prunifoliclla from Japan, but this species was nothing but the same one as malinella, malivorella, or ringoniella which were named by Matsumura.

In 1930, Stringer described Opogona* nipponica from Japan (Honshu) and Okinawa. In 1930, Matsumura illustrated 6 species as belonging to this family, but there were many mistakes in the determinations of their taxonomic situations as pointed out in later pages. Meyrick (1931-36) erected a new genus, Thermocrates*, and described a new species of Thermocrates, 3 new species of Decadarch is* and a new species belonging to Opogona, based on the specimens sent to him from Dr. S. Issiki. In 1932, Issiki illustrated Phyllocnistis* citrella Stainton, Lyonetia prunifoliella Hübner, and L. clerkella Linnaeus, and in 1950, he added Leucoptera susinella Herrich-Schäffer, Bedellia somnulen tella Zeller, Bucculatrix exedra Meyrick, and Tischeria* complanella Hiibner (misid.) to the fauna of Japan. In 1954, Inoue ennumerated all the species of Microlepidoptera which have hitherto been recorded from Japan. In 1957, Issiki illustrated

* These genera are excluded from the Lyonetiidae in this paper. 
Opogona cerodelta Meyrick and Bucculatrix crataegi Zeller (misid.) and the known species from Japan. Kuroko (1961) reported Lyonetia anthemopa Meyrick together with 2 seasonal forms and the life history of this species. Thus, the known species treated in this paper (except Decadarchis, Thermocrates, Opogona, Tischeria, and Phyllocnistis) amounted to 6 species within 4 genera.

The family Lyonetiidae which has been thought as a descendant of the Tineidae is composed of rather heterogenous genera. Certain primitive groups represent various degrees of development from Tineidae to Lyonetiidae and have a number of tineid characters, and some larvae of those are known as the feeders of fungi, vegetable refuse, decaying barks, and so on. As to the category of the family, various opinions have hitherto been expressed among the students. Thus, the family has not received any clear definition.

Stainton(1854) classified Tineina to include Lyonetia, Phyllocnistis, Cemiostoma, Opostega, and Bucculatrix in Lyonetiidae, and Bedellia and Tischeria in Elachistidae.

Meyrick (1881) erected Bedellidae, in which he included Tischeria, Bedeliia, Urodeta, Arctocoma, and Oenophila (perhaps). He separated this family from Lithocolletidae by the number of legs of the larva in having sixteen-legs, and Lyonetidae from Lithocolletidae by the basal joint of the antenna which is expanded into an eyecap.

Rebel (1901) subdivided Lyonetiidae into 2 groups, namely, Lyonetiinae and Phyllocnistinae. He placed Lyonetia and Phyllobrostis to the former, and Phyllocnistis, Cemiostoma, Bucculatrix, Opogona and Opostega to the latter. Bedellia and Tischeria were transferred to Gracilariidae.

Chapman (1902) classified Gracilaria and its allied genera mainly based on pupal and larval characters. Lyonetiadae was subdivided into 3 monogeneric subfamilies: Leucopterinae, Lyonetianae and Bedellianae. Phyllocnist is was transferred to Gracilariadae, and Bucculatrix and Tischeria were thought to belong to other families respectively.

Spuler (1910) regarded Cemiostoma as belonging to a separate family (Cemiostomidae), Bedellia and Bucculatrix to Gracilariidae, and Opogona to Oenophilidae. He also treated Pilyllocnistis and Tischeria as belonging to a separate family respectively (Phyllocnistidae and Tischeriidae).

Forbes (1923) considered that Leucoptera,Lyonetia, Bedellia, Phyllocnistis (with some doubt), Bucculatrix, and others are referable to Lyonetiidae, and Tischcria to Tischeriidae owing to the shape of the antennal scape which is not dilated to form an eyecap, the presence of scales on tongue and the forewing with fine spinules, and Opogona to Oinophilidae.

Hering (1927) almost agreed with Spuler (1910), and considered that each of the genera Piryllocnistis, Cemiostoma, and Tischeria belongs to a separate family. McDunough(1939) listed the generic and specific names of the family in his list of Microlepidoptera occurring in N. America in the similar concept to Forbes (1932), but he transferred Phyllocnistis to Gracillariidae.

Meyrick has regarded Phyllocnistis as belonging to Lyonetiadae till 1926, but put it in Gracilariadae since 1928. In 1929, he placed Opostega, Leucoptcia, 
Lyonetia, Bedellia, Tischeria, Bucculatrix, Oinophila,Dryadaula, and Opogona in Lyonetiadae. He erected more than 50 genera of Lyonetiidae from 1880 to 1937, but he included many primitive genera in this family.

Brues, Melander and Carpenter (1954) gave a key to the families of Lepidoptera, in which Lyoentia, Bucculatrix, Bedellia, Leucoptera, and Phyllobrostis were referred to Lyonetiidae, Opogona to Oenophilidae, and they put Phyllocnistis and Tischeria to a separate family respectively.

In his systematic list of the mining insects, Hering (1957) subdivided Lyonetiidae into the following groups: Oposteginae, Cemiostominae, Lyonetiinae, Bedelliinae, Tischeriine, Bucculatricinae, and Phyllocnistinae.

In his study on the larvae of the Lepidoptera, Gerasimov (1952) placed several genera to the family rank as follows: Bucculatrigidae, Lyonetiidae, and Leucopterygidae. The system of Gozmany (1956) showed similarity to that of Gerasimov (1952).

On the other hand, Viette $(1951,1954)$, Paulian \& Viette (1955), Diakonoff (1955), and Bradley $(1956,1957,1961,1962)$ have followed the Meyrick's concept.

It appears that this family was derived from the Tineidae which has an atrophied uncus in the male genitalia. Some of the groups derived from tineid stock acquired a leaf-mining habit. And through this habit there might have arisen such specializations as shown in the morphological modification in the larva, the diminution in the number of the wing venation and the dilation of the antennal scape forming an eyecap in the adult during a long period of time. Thus it can readily be imagined that the genera of Lyonetiidae in the strict sense have evolved.

However, these groups might have been evolved in rather various directions since branched from the tineid stock, and it is necessary to establish several subfamilies within the family to show much clearer phylogenetic relations between the genera. Thus it seems reasonable that Lyonetiidae may be subdivided into 4 subfamilies, namely, Bedelliinae, Bucculatricinae, Lyonetiinae, and Leucopterinae.

To my opinion, to place the transitional groups between Tineidae and Lyonetiidae out of Lyonetiidae may simplify the systematic concept of the family. Then, I think that Decadarchis and Thermocrates should be transfered to Erechthiidae. Because both of the genera have the head with wholly hairs, folded maxillary palpi, bristles on labial palpi, stout antennae, and nearly complete venation. Opogona should be transfered to Oinophilidae with some hesitation* by several distinctive characters from Lyonetiidae, such as the developed maxillary palpi, the heterogenous wing venation, and the conspicuously extensile female genitalia.

On the other hand, Tischeria differs from the forms of Lyonetiidae by the monotrysian type of female genitalia and aculeae on the basal portions of foreand hindwings, and Phyllocnistis is easily distinguishable by the conspicuously specialized larva and a regular row of bristles on the posterior tibia of the

* I have never examined Oinophila $v$-flava which was assigned to the type species of Oinophila. 
adult. Therefore such genera may be better excluded from Lyonetiidae and belong to separate families respectively.

Many of the specimens used in this study were collected by myself. Especially in the case of Lyonetia, Bedellia, and Leucopterinae, many of the larvae have been bred at the Hikosan Biological Laboratory and the emerged adults were thus gained.

The venation of this family is often found to be reduced considerably. As a matter of fact, to determine superficially the homology of the remaining veins is very difficult. In this paper, the terminology of the venation and the number of the vein followed Meyrick (19.28) mainly. However, as to the number, there still remain some questions which should be made clear by further studies. A s to the terminology of the genitalia, I followed that of Klots (1956). Unless otherwise stated, the type specimens treated in this paper are deposited in the collection of the Entomological Laboratory, Kyushu University.

I wish to express my sincere gratitude to Prof. K. Yasumatsu of Kyushu University for his kind direction in the courses of this study and for reading the manuscript. Dr. S. Issiki of Osaka, Prof. Dr. E. M. Hering of the Berlin Zoological Museum and Dr. G. Amsel of Landessammlungen für Naturkunde adviced me occasionally and offered me some valuable specimens. Dr. K. Sattler of the Zoologische Sammlung of Bayern State and Dr. J. F. Gates Clerke of the U. S. National Museum were kind enough to compare my specimens with the type specimens and gave me some valuable specimens for comparison. Messrs. J. Bradley and W. G. Tremewan of the British Museum (Natural History) took the trouble of comparing my specimens with the type specimens deposited in the Museum. Dr. T. Kumata also aided me in comparing my specimens with Matsumura's type specimens preserved in Hokkaido University. Mr. T. Yasuda of the University of Osaka Prefecture, and Dr. Y. Hirashima and the staff of the Entomological Laboratory of Kyushu University aided me in many ways. Dr. T. Hosokawa and Mr. M. Omura of the Faculty of Science of Kyushu University, Dr. M. Shimidu, Messrs. H. Ouchi, and T. Osada gave me the names of the host plants. I wish to express my hearty thanks to these gentlemen.

\section{Characters of the family}

Head rough or smooth; face smooth, strongly oblique. Ocelli absent. Labial palpi moderate or short, porrected or drooping, often rudimentary. Maxillary palpi usually obsolete, rarely short. Tongue short and naked, or obsolete. Antennae $2 / 3-1$ of forewing, often over 1 ; scape dilated and concave beneath, forming an eyecap, except Bedellia having an elongate and thickened scape. Mesothorax set with a rather long tuft of hairs on each side adjacent to base of underside of forewing. Posterior tibiae clothed with long or often rather short hairs, without bristles.

Forewings broad-lanceolate to narrow-lanceolate, apex usually acute, often caudate; aculeae only on basal angle; venation often much reduced, 7-10 veins present ; vein $1 \mathrm{~b}$ furcate or simple; discoidal cell usually present, reaching $2 / 3-$ 
$4 / 5$ of wing, lower margin of cell (cubital vein) running through the middle or near to middle of wing; 7 to costa; 11 from central area of cell or towards base or absent. Hindwings lanceolate to linear; cilia 3-7; discoidal cell opened; 5-6 veins usually present; 3 absent; 7 to costa or apex.

Male genitalia : Eighth abdominal segment with sclerotized arms or membranous lobes or hairy coremata in some genera; uncus absent, rarely weakly developed ; socii developed in Bucculatrix; gnathos usually present, in Lyonetia its arm on each side protruded posteriorly and often fused together distally; valvae generally small and weakly sclerotized; aedoeagus usually cylindrical, in some species of Leucopterinae with huge bulbous base.

Female genitalia : Ovipositor adapted for piercing in Lyonetia and some species of Bucculatrix; apophyses anteriores usually weak except Lyonetiu, absent in Bucculatrix; lamellae vaginales present or absent; corpus bursae membranous; signa present or absent.

Most of the larvae of this family are known as leaf miners, sometimes as feeders on the nibbling leaves, rarely as stem miners, as gall-makers or stem borers.

\section{Key to the Japanese subfamilies and genera of Lyonetiidae}

1. Forewing broad-lanceolate, with a metallic-colored tornal patch . . . . . .

... . . . . . . . . . . . . . . LEUCOPTERINAE, 2

Forewing 'lanceolate to narrow-lanceolate, without any tornal patch . . . 5

2. Head smooth. ................... . Leucoptera

Head tufted above .................... 3

3. Forewing with vein lb long furcate . . . . . . . . . . . . . . 4

Forewing with vein $\mathrm{lb}$ short furcate .......... Microthauma

4. Forewing with vein 4 present; hindwing with 5 and 6 present. . . . . .

....................... . . Proleucoptera

Forewing with vein 4 absent; hindwing with 5 present but 6 absent.

..................... Paraleucoptera

5. Scape forming an eyecap ..................... . 6

Scape not forming an eyecap ....... BEDELLIINAE, Bedellia

6. Antenna over 1 of forewing; forewing narrow-lanceolate.

. . . . . . . . . . . . LYONETIINAE, Lyonetta

Antenna under 1 of forewing; forewing lanceolate. . . . . . . . .

BUCCULATRICINAE, Bucculatrix

\section{Key to the Japanese subfamilics and genera of Lyonetiidae based mainley on male genitalia}

1. Eighth sternite forming 2 coremata ............... 2

Eighth sternite not forming 2 coremata ............. 3

2. Eighth tergite with an inner screlotized ridge and 2 projections of superuncus ; gnathos developed . . . . . . . LYONETIINAE, Lyonetia 
Eighth tergite without any inner ridge and superuncus; gnathos undeveloped. ............ BEDELLIINAE, Pedcllia

3. Eighth sternite with 2 valva-like processes; socii absent ........ .................... . . . LEUCOPTERINAE, 4

Eighth sternite without any valva-like processes; socii present $\ldots \ldots$.

BUCCULATRICINAE, Bucculairix

4. Gnathos present ....................... 5

Gnathos absent. $\ldots \ldots \ldots$ Paraleucoptera

5. Gnathos divided into 2 parts. .............

Gnathos not divided into 2 parts ........... Microilhatima

6. Valva rather sclerotized $\ldots \ldots \ldots \ldots$ Leucoptera

Valva usually small and weak ............ Prolencoptera

\section{Subfamily BEDELLIINAE}

\section{Genus Bedellia Stainton}

(P1. 2, fig. 16)

Bcdellia Stainton, 1849, Syst. Cat. Brit. Tin. : 23 ; id., 1854, Ins. Brit. Lep. : 226; Meyrick, 1393, Proc. Linn. Soc. N. S. Wales, 7: 599 ; id., 1895, Hand. Brit. Lep. : 758; Spuler, 1910, Schmett. Europ., 2: 418; Forbes, 1923, Cornell Univ. Agr. Exp. Sta. Mem. 68: 153; Meyrick, 1929, Rev. Hand. Brit. Lep.: 811.

Type species : Lyonetia somnulentella Zeller, 1847.

Head widely roughly tufted above; face smooth. Ocelli absent. Labial palpi rather short, porrected, pointed. Maxillary palpi rudimentary. Tongue rather short, naked. Antennae 1 of forewing, $\hat{o}$ simple; scape elongate and rather thickened, with a large, dense pecten. Posterior tibiae with short hairs above and below. Abdomen unspined.

Forewings narrow-lanceolate; vein lb furcate, upper branch weak ; $3-4$ absent ; 6 and 7 stalked ; 8 absent ; 9 stalked with 6 -t-7 at a short distance beyond acuminate apex of discoidal cell; 11 from $3 / 5$ of discoidal cell. Hindwings $1 / 2$, linear-lanceolate; cilia 5--6 ; transverse vein absent between 2 and 5; 3 and 4 absent.

Male genitalia: Eighth tergite protruded beyond tegumen; 8th sternite forming 2 coremata clothed with long hairs; genital ring elliptical, without uncus; gnathos undeveloped; valvae oblong; aedoeagus tubular.

Female genitalia: Papillae anales triangular ; ostium bursae weak ; ductus bursae slender; corpus bursae elongated, with a crescent signum.

\section{Bedellia somnulentella (Zeller)}

(P1. 3, fig. 24; PI. 5, fig. 37 ; Pl. 11, fig. 57 ;P1.14, figs. 72 \& 73)

Lyonetia sommulentella Zeller, 1847, Isis (Oken). 12: 894.

Bedellia orpheella Stainton, 1849, Syst. Cat. Brit. Tin.: 23.

Bedellia somnulentella: Stainton, 1851, Sppl. Cat. Brit. Tin. : 25; id., 1854, Ins.

Brit. Lep. : 226; Meyrick, 1893, Proc. Linn. Soc. N. S. Wales, $7: 600$; id., 1895,

Hand. Brit. Lep.: 758; Rebel, 1901, in Staudinger-Rebel, Cat. Lep. Pal., 2 : 
210 ; Walsingham, 1907, Proc. 2001. Soc. London, 1907 : 984; id., 1907, Fauna Hawaii., 1: 723, pl. 25, f. 28; Spuler, 1910, Schmett. Europ., 2 : 418; Fletcher, 1921, Mem. Dept. Agr. India, Ent. Ser. 6: 174; Forbes, 1923, Cornell Univ. Agr. Exp. Sta. Mem. 68: 153; Meyrick, 1929, Rev. Hand. Brit. Lep. : 811; Pierce \& Metcalfe, 1935, Genitalia Tin. Fam. Lep. Brit. Is. : 90, pl. 55; Issiki, 1950, in Icon. Ins. Jap., (ed. 2): 444, f. 1195; Inoue, 1954, Check List Lep. Jap., Part 1: 24 ; Kuroko, 1957, Enum. Ins. Mont. Hikosan, 1. Lep. : 2; Issiki, 1957, in Icon. Het. Jap. Col. Nat., 1: 19, pl. 3, f. 62; Okano, 1959, in Icon. Ins. Jap. Col. Nat., 1: 279, pl. 182, f. 22 ; Bradley, 1961, Bull. Brit. Mus. (Nat. Hist.) Entomology, 10 (4) : 160.

Gracilaria convolvulclla Fologne, 1860, Ann. Soc. Ent. Belg., 4: 86.

Bedellia (?) staintoniella Clemens, 1860, Proc. Ac. Nat. Soc. Phil., 12: 8.

Bedelliamnesileuca Meyrick, 1928, Exot. Microlep., 3 : 397.

Bedellia ipomoeae Bradley, 1953, Proc. Hawaii. ent. Soc., $15: 114$.

ô․ 8-11 mm. Head and thorax pale ochreous; tuft mixed with brown. Labial palpi whitish-ochreous. Antennae whitish-grey ringed with fuscous. Abdomen pale ochreous, dorsal area dark ochreous.

Forewings pale ochreous, coarsely irrorated with fuscous, dorsal half paler; cilia pale ochreous-grey, irrorated with fuscous in costal and apical cilia. Hindwings pale grey; cilia pale ochreous-grey.

Sometimes, we may find such a melanistic form (autumnal form) as described below: head and thorax pale greyish-ochreous, irrorated with dark fuscous. Forewings pale greyish-ochreous, irrorated with dark fuscous or black, densely towards base, paler along dorsum but more or less located blackish irrorations at $1 / 4,1 / 2$ and on tornus.

Male genitalia : Genital ring elliptical ; gnathos undeveloped, but prepared with a pair of weakly sclerotized patches; valvae curved upwardly, armed with a spine at distal end, sacculus gently angulated; aedoeagus tubular, tapered towards apex; coremata with very long hairs.

Female genitalia: Apophyses anteriores short and weak ; apophyses posteriores longer; ostium bursae faintly sclerotized; ductus bursae slender; inception of ductus seminalis broad; corpus bursae elongated and with 2 small spinose plates near juncture with ductus, a long straight intestinal pattern and a crescent signum of spines.

Specimens examined : 1ô, Tokyo, Honshu, 1 Aug. 1933 (A. Kawada); 2 우, Mt.

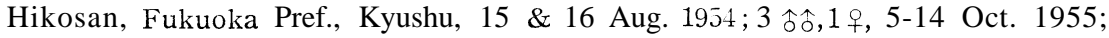

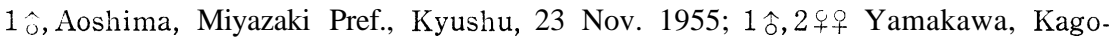
shima Pref., Kyushu, 19 Oct., 1956; $1 \hat{\text { ô }}$ Kagoshima City, Kagoshima Pref., Kyushu,

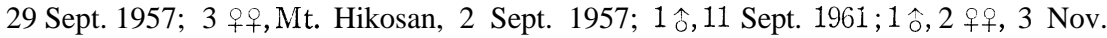

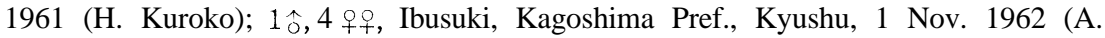
Nagatomi).

Distribution : Japan (Honshu, Shikoku, Kyushu), Europe, India, Java, Australia, Queensland, Solomon Isls., Africa, New Zealand, Hawaii, N. America, S. America.

There are 2 races in this species of Japan. One is the race which was only once bred from Ipomoea purpurea Lam., collected at Yamakawa. The other 
is a race which was bred from Ipomoea Batatas Lam., Calystegia japonica Choisy, and others. In female genitalia, the former has a signum which is nearly coincide with that of the European race, but signum of the latter is larger than that of the European race and shows a horseshoe shape.

It must be determined by a further study based on more materials, whether these Japanese races are somnulentella truly, or represent some subspecies within the nominate race, or are better to devide into different species.

\section{Biological notes}

Host plants : Convolvulaceae-Ipomoea Batatas Lam. (Jap. name : Satsumaimo), i.hederacea Jacq. (Jap. name : Asagao), I. purpurea Lam. (Jap. name :Marubaasagao), I. indica (Burm.) Merrill (Jap. name: No-asagao), Calystegia Soldanella \&inn.) Roem. et Schult. (Jap. name: Hama-hirugao), C. japonica Choisy (Jap. name: Hirugao), in Japan. Calystegia Sepium, C. Soldanella, Convolvulus althaevides, C. arvensis, C. cantabrica, C. mauretanica, C. floridus, Pharbitis sp., Ipomoea purpurea, I. sp., in foreign countries.

The egg is deposited on the upper side of the leaf along a rib; oval; $0.3 \times 0.2$ min. in size. The larva, as soon as hatched, mines in a linear line (about 30 $\mathrm{mm}$. in length) along ribs, subsequently it leaves the early mine, and bores again into the leaf and extends in a pale brownish, semitransparent, polygonalblotch. The blotch mine is not contained any frass, because the larva ejects the frasses from a hole prepared on the lower side of the mine. The larva rests in the silken threads stretched on the underside of the leaf, except on feeding and sometimes migrates from one leaf to another. The naked angulated pupa is suspended at the joint of some cross silken threads.

The larvae occur from the end of July to the middle of August and from the middle of September to the middle of October on Mt. Hikosan, and the adults appear from the middle of August to the beginning of September and from the end of September to the beginning of November.

\section{Subfamily BUCCULATRICINAE}

\section{Genus Bucculatrix Zeller}

Eucculatrix Zeller, 1839, Isis (Oken) : 215 ; Stainton, 1854, Ins. Brit. Lep. : 290; Meyrick, 1893, Proc. Linn. Soc. N. S. Wales, 7: 600 ; id., 1895, Hand. Brit. Lep. : 729 ; Spuler, 1910, Schmett. Eur., 2: 418; Forbes, 1923, Cornell Univ. Agr. Exp. Sta. Mem. 68 : 155; Meyrick, 1929, Rev. Hand. Brit. Lep. : 813; Pierce \& Metcalfe, 1935, Genitalia Tin. Fam. Lep. Brit. Is.: 91.

Type species : Lyonetia albedinella Zeller, 1839 ( = boyerella Duponchel). Ceroclastis Zeller, 1848, Linn.. Ent. 3: 295.

Type species : Lyonetia nigricomella Zeller, 1839.

Head roughly tufted above; face smooth. Ocelli absent. Labial palpi minute. Maxillary palpi rudimentary. Tongue short and naked. Antennae $2 / 3$ of forewing, ô simple; scape dilated and concave beneath, with a dense pecten, forming 
an eyecap; 1st segment of flagellum slightly long, and in male with a deep notch. Posterior tibiae clothed with long hairs above and short hairs below. Abdomen unspined; an eversible sac with a flower-like patch of specialized scales in suture between 2nd and 3rd abdominal segments on dorsal side.

Forewings lanceolate and shortly caudate ; vein $\mathrm{lb}$ simple; discoidal cell elongated; 2 and 5 very short, and from near apex of cell, 2 sometimes obsoles. cent or absent ; 3 and 4 absent; 6 and 7 stalked ; 9 and 10 very short; 11 from before middle of discoidal cell. Hindwings $2 / 3$; narrow-lanceolate, cilia 3-4; transverse vein absent between 2 and 5; 3 and 4 absent ; 6 and 7 stalked.

Male genitalia: Uncus absent; socii developed to form 2 setose lobes ; valvae tapered or rounded, sometimes bilobed, basal angles of costae usually produced as free arms; saccus sometimes semicircular ; aedoeagus rather elongate, more or less cylindrical.

Female genitalia : Ovipositor modified for rasping or piercing in some American species ; apophyses anteriores absent; genital plate often densely set with scales; near juncture with ductus, corpus bursae with a signum, consisting of spined ribs.

The larvae when very young (1st and 2nd instar) are miners, forming short tortuous or spiral mines. At the end of 2nd instar, the larva quits the mine, and on the surface of the leaf spins a cocoon-shaped web (cocoonet, Stainton, 1862: 6), within which the larva remains motionless in a U-shape for a considerable time. After the $2 \mathrm{nd}$ molt, the larva proceeds to eat the epidermis of one side and some mesophyll. When full-fed, it leaves the feedling place, and spins an elongate ribbed cocoon. In N. America, the larvae of some species are known as gall-makers and stem borers.

\section{Key to the species of Bucculatrix based on marking}

Forewing with ochreous-orange patches ; apical cilia with a fuscous median line.

Forewing with very obscure yellowish-brown patches; apical cilia without a median line. $\ldots \ldots \ldots \ldots \ldots \ldots \ldots$. $\ldots \ldots$. $\ldots \ldots$ Meyrick

\section{Key to the species of Bucculatrix based on male genitalia}

Socii weak ; valvae fused with vinculum; aedoeagus broadened towards base. .................. . . pyrivorella sp. nov. Socii oblong; valvae separated from vinculum; aedoeagus slender. ..

\section{Key to the species of Bucculatrix based on female genitalia}

Ostium bursae very broad cup-shaped; ductus bursae short and anirum bulged.

pyrivorella sp. nov.

Ostium bursae slender tubular; ductus bursae very long and slender . . . . . ....................... exedra Meyrick 
Bucculatrix pyrivorella sp. nov.

(P1. 5, fig. 34 ; Pl. 11, fig. 55)

Eucculatrix crataegi: Issiki, 4957, in Icon. Het. Jap. Col. Nat., 1: 18, pl. 2, f. 58 (nec Zeller, 1839).

今ㅇ. 7-7.5 mm. Head ochreous-white; tuft mixed with yellowish-brown hairs centrally. Antennae ochreous-white ringed with fuscous to black. Thorax ochreous-white, with some ochreous-orange scales. Abdomen bronzy-grey above ochreous-white below; anal tuft of male ochreous-white.

Forewings ochreous-white, with some fuscous irrorations ; ochreous-orange streaks or patches as follows: one along fold from near base to $1 / 3$, one patch from middle to $2 / 3$ above dorsum, with a black plical dot basally, one along costa from base to $1 / 3$, whence obliquely to disc at $2 / 3$, one from beyond middle of costa joining with preceding streak in disc and extending beyond tornus, one patch near apex of costa, sometimes a few black scales in disc at 3/4; cilia ochreous-white, greyish-brown on costa and apex, with some blackish irrorations on costa, apex and termen, and a blackish median line round apex. Hindwings grey; cilia pale grey.

Male genitalia: Socii, weakly sclerotized lobes, clothed with rather long hairs ; valvae rather short, fused with vinculum; saccus rounded anteriorly, and another spatulate process posteriorly ; aedoeagus broadened towards base, vesica protruded, verrucose.

Female genitalia : Ostium bursae very broad and cup-shaped; ductus bursae rather short, antrum bulged, weakly sclerotized; corpus bursae with a signum of many spinous series.

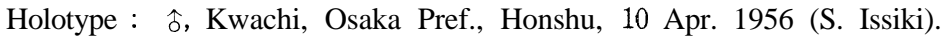

Ailotype : $q$, the same as holotype.

Paratype : $1 \hat{\mathrm{o}}$, the same as holotype.

Distribution : Japan (Honshu).

Host plant : Rosaceae--Pyrus pyrifolia(Burm. f.) Nakai var. culta (Makino) Nakai (Jap. name : Nashi).

This new species is very closely related to Bucculatrixcrataegi (Zeller), but the latter has the paler markings with many blackish irrorations. And in the male genitalia the vesica is set 2 longitudinal rows of spines, and in the female genitalia the ostium bursae is narrower. This species is included in Section VI mentioned by Braun (1963).

\section{Bucculatrix exedra Meyrick}

(Pl. 3, fig. 23 ; Pl. 5, fig. 36; Pl. 11, fig. 54 ; Pl. 14, fig. 71)

Buculatrixexedra Meyrick, 1915, Exot. Microlep., 1: 354: Fletcher, 1921, Mem.

Dept. Agr. India, Ent. Ser. 6 : 175 ; Issiki, 1950, in Icon. Ins. Jap., (ed. 2):

443, f. 1193; Inoue, 1954, Check List Lep. Japan., Part 1: 23; Kuroko, 1957, 
Enum. Ins. Mont. Hikosan, 1. Lep.: 2; Issiki, 1957, in Icon. Het. Jap. Col. Nat., 1: 19, pl. 2, f. 59.

소우. $8 \mathrm{~mm}$. Head ochreous-white; tuft slightly sprinkled with brown posteriorly. Antennae pale greyish-ochreous ; eyecap pale ochreous. Thorax pale ochreous, with some fuscous irrorations. Abdomen bronzy-grey above, ochreouswhite below.

Forewings ochreous-white, suffused with yellowish-ochreous, with a few dark fuscous irrorations; very obscure yellowish-brown patches are found as follows : one along fold from base to $1 / 3$, one on dorsum near $2 / 3$, another from costa at $1 / 2$ to disc near $4 / 5$; a black plical dot near middle, a dot of black irroration at $4 / 5$, cilia whitish-ochreous, yellowish-ochreous towards apex, with blackish irrorations on costa and apex. Hindwings grey; cilia pale grey.

Male genitalia : Socii, parallel-sided oblong lobes, clothed with fine hairs; valvae separated from vinculum, rounded at apex; aedoeagus elongated vesica slightly rolled.

Female genitalia : Ostium bursae slender tubular; ductus bursae very long and slender; corpus bursae with a mass of long spines.

Specimens examined: $3 \hat{o} \hat{\delta}, 1$ ㅇ, Mt. Hikosan, Fukuoka Pref., Kyushu, 9 May

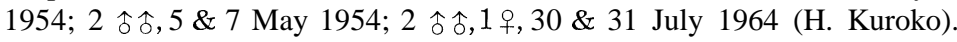

Distribution : Japan (Honshu, Shikoku, Kyushu), India.

This species belongs to an unknown section but I suppose it may be an ancient species of Section VIII mentioned by Braun (1963).

\section{Biological notes}

Host plant : Sterculiaceae-Firmiana platanifolia (Linn. fil.) Schott. et Endl. (Jap. name : Aogiri) in Japan.

The eggs are deposited on the lower surface of the leaf of the host plant, along or not along a rib; oval, rather flattened, facetted on surface; $025 \times 0.20$ $\mathrm{mm}$. in size. Newly hatched larva bores immediately and proceeds to mine in a spiral line. The spiral linear mine is an upper surface mine; blackish brown, freshly mined portion pale green; about $10 \mathrm{~mm}$. in length. In the 2nd instar, the larva quits the mine, and on the surface of the leaf spins a thin, flattened, whitish cocoonet (about $1.0 \mathrm{~mm}$. in diameter), in which the larva remains in a U-shaped status for a considerable time and undergoes the 2 nd moult. The 3rd instar larva nibbles the epidermis and some mesophyll on the upper surface of the leaf. A 2nd cocoonet, like the 1st, is spun at the end of the 3rd instar. But, the 2nd differs from the 1st by the size (about $1.7 \mathrm{~mm}$. in diameter) and the coloration of pale yellowish-brown. When full fed, the larva descends to the ground by silk or moves to some convenient place, and spins an elongate cocoon on the twig, or the trunk, or lower surface of the leaf. The cocoon is spindle- and bilge-shaped, with 5-7 longitudinal ribs on the surface; whitish to pale brown ; about $5 \mathrm{~mm}$. in length, $1 \mathrm{~mm}$. in width, and $0.8 \mathrm{~mm}$. in thickness. The surroundings of the cocoon is enclosed with 20 and over vertical silken threads which is arranged elliptically, 


\section{Subfamily LYONETIINAE}

Genus Lyonetia Huebner

(P1. 2, fig. 18)

Lyonetia Huebner, [1825], Verz. bekannt. Schmett., (27): 423 ; Stainton, 1854, Ins. Brit., Lep. : 283; Meyrick, 1895, Hand. Brit. Lep. : 756; Spuler, 1910, Schmett. Europ., 2 : 422 ; Forbes, 1923, Cornell Univ. Agr. Exp. Sta. Mem. 68 : 152; Meyrick, 1929, Rev. Hand. Brit. Lep. : 810.

Type species : Tineaclerkella Linnaeus, 1758.

Head roughly tufted above; face smooth. Ocelli absent. Labial palpi short or moderate, smooth, straight, drooping, terminal joint longer than the second, pointed or obtuse. Maxillary palpi rudimentary. Tongue short, naked. Antennae 1-1 1/2 of forewing, o simple; scape dilated with scales and concave beiow to form an eyecap. Posterior tibiae with short hairs above. Abdomen unspined.

Forewings narrow-lanceolate, parallell-sided, long-caudate ; vein lb long-furcate ; discoidal cell very long, reaches $2 / 3$ to $3 / 4$ of wing, apex nearly acute-angled; 3 present or absent; 4 absent; 6 sometimes absent; 7 to costa slightly above apex; 8 absent; 11 from slightly beyond middle of discoidal cell. Hindwings
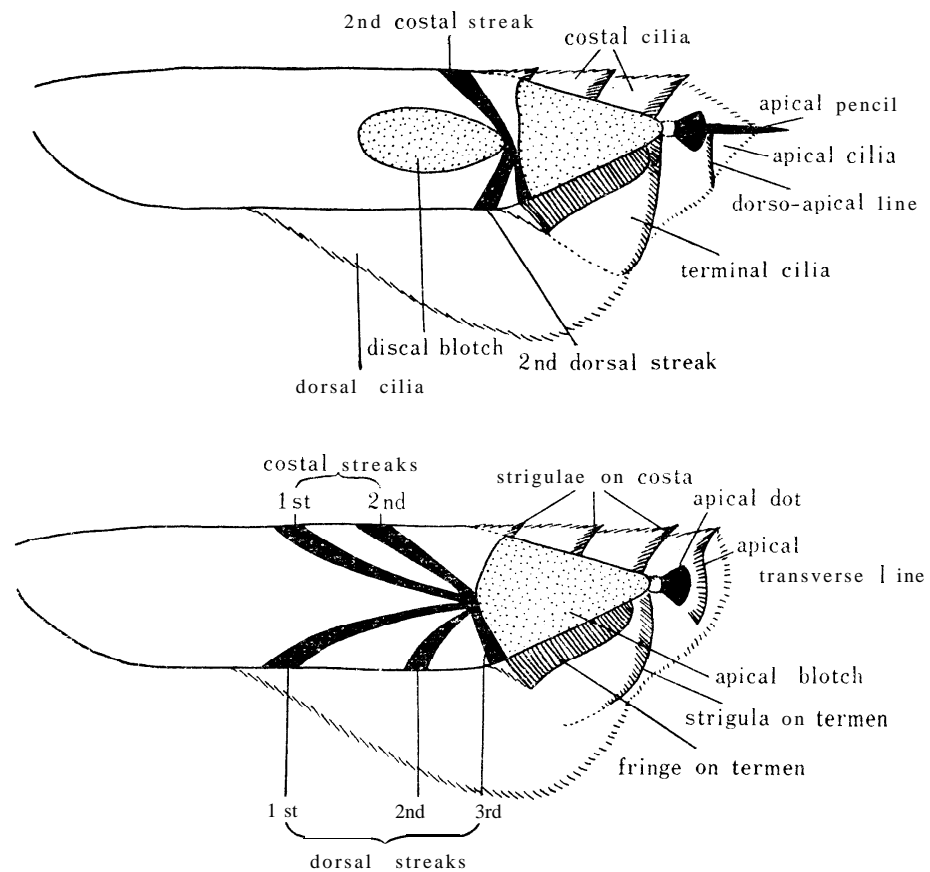

Fig. 1. Diagrammatical illustration of forewings of Lyonetia. 
1/2, linear-lanceslate ; cilia 6-7; venation much reduced ; transverse vein absent ; 3 absent; 4 present or absent; 6 absent.

Male genitalia : Eighth tergite with an inner longitudinal sclerotized ridge and a pair of sclerotized arms or of membranous lobes which seem to form a superuncus projecting backwards from posterior margin of the tergite ; ventral side of 8th sternite with a pair of coremata, which will project posteriorly by a pressure of body fluid ; tegumen and vinculum fused completely, forming a rather broad ring; an arm of gnathos projecting posteriorly on each side and both of the. arms often fused together distally; valvae oblong, weakly sclerotized, often fused together in basal half; saccus slenderly projecting or triangularly pointed; aedoeagus cylindrical, sometimes armed with a scobinated area near apex.

Female genitalia : Ovipositor adapted for piercing and with file-like teeth; apophyses anteriores and apophyses posteriores well developed to form strong rods; genital plate with a sclerotized anterior band; ostium bursae usually tubular, membranous, sometimes cup-shaped ; ductus bursae usually elongated and slender, rarely short and thick, often with 1 or 2 small sclerotized patches near inception of ductus seminalis; 2 signa present, sometimes absent or single.

Markings: Most of the species of this genus are ornamented with some common markings as described below. Forewings with a discal blotch in disc, this blotch usually yellow or yellow-orange, margined by fuscous, at distal end of this blotch costal and dorsal streaks meeting in a point. If the discal blotch is absent, 1st and 2nd costal streaks emitting from costa, Ist-3rd dorsal streaks from dorsum, all streaks converging in a point at disc; apical blotch usually yellow or yellow-orange ; a blackish fringe on termen (terminal fringe); costal cilia usually with 3 strigulae (strigulae on Costa); apical dot roundish or sub. triangular; an apical pencil, an apical transverse line or a dorso-apical line in apical cilia ; from distal end of apical blotch a gently curved strigula in terminal cilia (strigula on termen).

This genus may be separated into 2 subgenera by the length of antennae, the presence or absence of vein 3 in the forewings and of vein 4 in the hindwings, and the characters of superuncus and gnathos.

\section{Key to the subgenera and species of Lyonetia based on marking}

1. Forewing with a discal blotch. . . . . . . . (Lyonctia s. str., part), 2 Forewing without a discal blotch ................

2. Discal blotch placed above fold......... clerkella (Linnaeus

Discal blotch reaching dorsum ...................3

3. Discal blotch with whitish scales towards tornus along dorsum; middle strigula on costa perpendicular . . . . . . . . bakuchia sp. nov.

Discal blotch without whitish scales towards tornus; middle strigula on costa outwardly-oblique. . . . . . . . . . . . yasudai sp. not..

4. Forewing with an apical transverse line ..... . (Lyonetia s. str., part)? 5 Forewing without an apical transverse line ....... (Lyonetiola) 3 
3. Forewing bornzy-grey, except an apical blotch. ....boehmeriella sp. nov. Ground color of forewing white or pale greyish-fuscous ......6

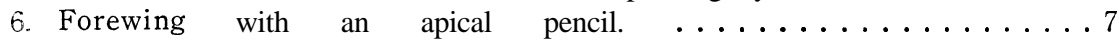
Forewing without an apical pencil ........... anthemopa Meyrick

- Forewing with blackish 1st dorsal streak; sometimes costal half blackish. fuscous; alar expanse $8-10 \mathrm{~mm}$... . prunifoliella malinella (Matsumura) Forewing usually without 1 st dorsal streak; if present, the streak tinged with yellowish, interrupted or constricted on fold; alar expanse 7-8

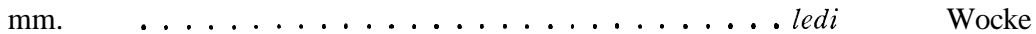

8. Fore-wing with an apical pencil or an oblique apical line . . . . . . . . 9 Forewing without any apical pencil or oblique apical line .......

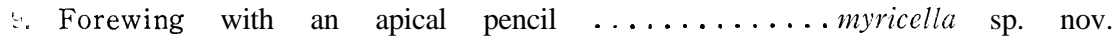
Forewing with an oblique apical line ......... castaneella sp. nov.

\section{Key to the subgenera and species of Lyonetia based on male genitalia}

¿. Superuncus sclerotized; gnathos sclerotized, distal parts of arms fused together or approximated . . . . . . . . . (Lyonetia s. str.), 2 Superuncus membranous; gnathos membranous, rarely sclerotized to form narrow arms, widely separated ......... (Lyonetiola), 8

Distal parts of arms of gnathos approximated ........... . 3

Distal parts of arms of gnathos fused together. . . . . . . . . . 6

3. Apices of arms of gnathos pointed or bruntly pointed; aedoeagus slender

Apices of 'arms of gnathos slightly splitted; aedoeagus 'stout .. ledi Wocke Sclerotized ridge on 8th tergite long; arms of superuncus widely separated clerkella (Linnaeus)

Sclerotized ridge on 8 th tergite short; arms of superuncus adjacent to each other....................... 5

๖. Saccus short; aedoeagus rather short, tapered towards apex ...... . bakuchia sp. nov.

Saccus long, pointed; aedoeagus long, apical half 'slender with some spines ventrally ...... . . . . . . . . . . yasudai sp. nov.

6. Arms of superuncus broad; distal part of gnathos bifid . . . . . . . .

. . . . . . . . . . . . . . . . . boehmeriella sp. nov. Arms 'of superuncus narrow; apex of gnathos with 2 or 3 pairs of projections . . . . . . . . . . . . . . . . . . . 7 Apex of gnathos with 2 pairs of projections .... anthemopa Meyrick Apex of gnathos with 3 pairs of projections ............

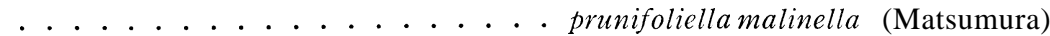

8. Gnathos clerotized. ............. euryella sp. nov. Gnathos membranous. . . . . . . . . . . . . . . . . . . . 9 9

9. Apex of aedoeagus smooth ........... myricella sp. nov.

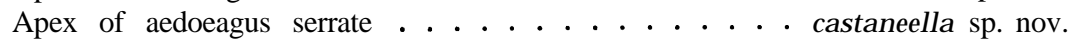




\section{Key to the subgenera and species of Lyonetia based on female genitalia}

1. Corpus bursae with 1 or 2 signa ................. . 2 Corpus bursae without any Signum. . . . . . (Lyonetia s. str., part; 7

2. Genital plate longitudinally sclerotized, without a sclerotized lamella antevaginalis ............. . (Lyonetia s. str., part], 3 Genital plate not sclerotized, with a sclerotized lamella antevaginalis . . .

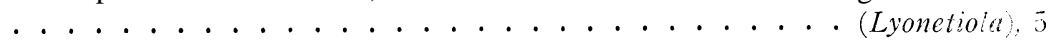

3. Corpus bursae with a short thorn-shaped signum. . . clerkella (Linnaeus)

Corpus bursae with 2 long signa................. 1

t. Signa symmetrical; ductus bursae with 2 small sclerotized patches at middle .................... . . yasudai sp. nov.

Signa asymmetrical ; ductus bursae with a small sclerotized patch near ostium. . . . . . . . . . . . . bakuchia sp. nov.

5. Signa long triangular ............. euryella sp. nov. Signa linear ...................... 6

6. Lamellae vaginales semicircular ; ductus bursae with a elongate sclerotized patch ................. . . myricella sp. nov. Lameliae vaginales round; ductus bursae with a round sclerotized patch. . .................. . castaneella sp. nov.

7. Ductus bursae broad and very short. ....... boehmcriella sp. nor. Ductus bursae not short ................. 8

8. Ductus bursae broad, slightly sclerotized, and reticulated in posterior 33 . without a sclertized plate; corpus bursae round...... . ledi Wocke Ductus bursae slender, with a sclerotized plate; corpus bursae oval or narrow elliptical .................... 9

9. Ductus bursae with a sclerotized plate near juncture with corpus bursae: corpus bursae minutely spined .......... anthemopa Meyrick Ductus bursae with a T-shaped sclerotized plate at middle; corpus bursae

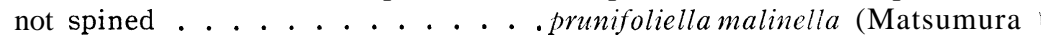

Lyonetiola subgen. nov.

Type species : Lyonetia(Lyonetiola) castaneella sp. nov.

Antennae about $11 / 2$ of forewings; forewings vein 3 present, rather approximated to 2; hindwings 4 present ; superuncus consists of a pair of membranous lobes; arms of gnathos widely separated.

These characters suggest that the subgenus Lyonetiola may be more primitive than the subgenus Lyomtia.

\section{Lyonetia (Lyonetiola) castaneella sp. nov.}

(P1. 1, figs. 10a \& 10b; PI. 3, fig. 25; P1. 6, fig. 38 ; P1. 12, fig. 58)

Aestival form : 令우. 6.5-7.0 mm. Head, tuft, face, thorax and abdomen shi ning white. Labial palpi shining white, terminal joint pale fuscous externally. Antennae $11 / 2$ of forewing; greyish-fuscous, becoming white towards base : eyecap shining white. Posterior legs shining white; tibiae with a fuscous an- 
nulation at apex; 1st and 2nd tarsal joints tipped with fuscous, remainders suffused with greyish-fuscous internally.

Forewings very narrow-lanceolate; shining white; streaks yellowish-brown somewhat tinged with fuscous, 1 st costal streak very obliquely from $2 / 3,2$ nd costal streak in parallel with 1 st one from $3 / 4$, these streaks not reaching half across wing, 1st dorsal streak very obliquely from $2 / 5$ reaching half across wing, 3 rd dorsal streak from tornus along termen, not reaching apex, 2nd dorsal streak arising just before 3rd and reaching inner border of apical blotch, 2nd and 3rd dorsal streaks parallel to each other; an indistinctly bordered yellowishbrown apical blotch along termen from $4 / 5$ to just before apex, more or less diffused towards costa; blackish fringe on termen; costal and terminal cilia white, with 2 pale fuscous strigulae in costal cilia, a slightly curved fuscous strigula from end of apical blotch in terminal cilia; some white scales before black apical dot; an outwardly oblique fuscous apical line beyond apical dot; dorsal cilia pale fuscous. Hindwings and cilia pale fuscous.

Autumnal form : ㅇ․ $8.5 \mathrm{~mm}$. This form differs from the above one in the following characters :

1. Head, tuft, eyecap and thorax golden-yellow tinged with brown; face silvery-white slightly tinged with golden.

2. Forewings golden-yellow ; costal half and basal area suffused with fuscous ; 1 st dorsal and 1st costal streaks broadened.

Male genitalia : Sclerotized ridge on 8th tergite weak and short, anterior edge gently curved ; lobes of superuncus slightly narrowed posteriorly; anus surrounded by a sclertized hoop; each arm of gnathos membranous, apex fingershaped, with 2 short setae; valvae oblong, rather elongated ; saccus slenderly elongated; aedoeagus sinuous cylindrical, apex thickened, irregularly serrated and armed with a longitudinally scobinated area.

Female genitalia : Genital plate with a rather broad sclerotized anterior band; lamellae vaginales round ; ductus bursae rather broad, with a round weakly sclerotized patch near inception of ductus seminalis: corpus bursae with 2 linear signa.

Holotype : $\hat{o}$, Mt. Hikosan, Fukuoka Pref., Kyushu, 10 Aug. 1955 (H. Kuroko).

Allotype : 우 the same as holotype, 8 Aug. 1955 (H. Kuroko).

Paratypes : $4 \hat{\delta} \hat{\circ}, 2$ 우, the same as holotype, 3-11 Aug. 1954; $1 \hat{\circ}, 8$ Aug. 1955. Autumnal form-1 $q$, the same as holotype, 20 Oct. 1954 (H. Kuroko).

Distribution : Japan (Kyushu).

This new species is distinguishable from Lyonetiaacromelas Turner, 1933, of Queensland in having the 1 st dorsal streak at $2 / 5$ of the forewing and the oblique apical line in the apical cilia.

\section{Biological notes}

Host plants : FagaceaE-Castaneacrenata Sieb. et Zucc. (Jap. name : Kuri), Quercus acutissima Charruthers (Jap. name : Kunugi). 
Mine : An irregular blotch mine; pale brown to whitish-green; semitransparent; feeding area being about $65 \mathrm{~mm}$ ? The mine is made on a young leaf; it extends from the apex of the leaf towards the base in an irregular blotch along the margin of the leaf. The blackish frasses are ejected from the holes which are made on the lower side of the mine, but some frasses are scattered in the mine. The larva is able to migrate easily from one leaf to another. When full fed, the larva quits its mine and spins a hammock-like cocoon on the lower side of the leaf. One or 2 mines are found on a single leaf.

Development : The number of generation is unknown, but the larvae occurred at the end of July, from the beginning to the middle of August and from the beginning to the middle of October on Mt. Hikosan, and the adults appeared at the beginning of August, at the end of August and at the end of October.

Lyonetia (Lyonctiola) myricella sp. nov.

(Pl. 1, figs. 9a \& 9b; Pl. 6, fig. 33; P1. 12, fig. 59; Pl. 16, fig. 81)

Aestival form : $\quad 7 \mathrm{~mm}$. Head, face, tuft and thorax shining white. Labial palpi white, terminal joint pale fuscous externally. Antennae $11 / 3$ of forewing; greyish-fuscous, becoming white towards base ;eyecap shining white. Posterior legs white; tarsal joints annulated with black. Abdomen greyish-fuscous above, shining white below.

Forewings narrow-lanceolate; shining white, costal margin faintly greyish; streaks greyish-fuscous, 1 st costal streak from $2 / 3$, 2nd costal streak from beyond it, 1 st dorsal streak from middle, broadened on dorsum, broad 2 nd dorsal streak from $2 / 3$, 3rd dorsal streak from beyond it, all streaks reaching apical blotch; a yellow-orange apical blotch occupying apical $1 / 4$ of wing, somewhat diffusing inwardly; blackish fringe on termen; costal and terminal cilia white, 3 blackish strigulae in costal cilia; apical dot black, with an apical pencil and a dorso-apical line; dorsal cilia greyish-fuscous. Hindwings and cilia greyishf uscous.

Autumnal form : $9.5 \mathrm{~mm}$. This form differs from the above one in the following characters :

1. Head tinged with fuscous; tuft mixed with a few blackish hairs. Thorax greyish-fuscous above, shining white beneath.

2. Forewings with a dark fuscous patch from base to beyond middle on dorsal half, outer border very oblique and extending near $3 / 4$ in disc, beyond this suffused with pale yellowish-brown.

Male genitalia: Sclerotized ridge on 8th tergite weak and short, anterior edge gently curved; superuncus represented by a pair of membranous, semicircular lobes; tegumen and vinculum fused completely, forrning a broad ring : anus surrounded by a sclerotizecl hoop; gnathos consisting of a pair of membranous finger-shaped projections, 2 short setae at apex; "valvae nearly rectangular ; saccus rather pro jecting, obtusely pointed ; aedoeagus cylindrical, curved downwards at apical 1/3, apex obtuse and armed with a scobinated area.

Female genitalia : Genital plate with an arcuated sclerotized anterior band: 
lamellae vaginales semicircular ; ostium bursae slender, membranous; ductus bursae rather long, with a elongate weakly sclerotized patch near inception of ductus seminalis; signa indistinctly lined along margin of corpus bursae.

Holotype: 今, Ambō, Yakushima, Satsunan Isls., 9 Nov. 1959 (I-I. Kuroko).

Allotype : + , Mt. Kaimon, Kagoshima Pref., Kyushu, 23 Nov. 1955 (H. Kuroko).

Paratypes : $2 \hat{\circ} \hat{o}, 1$, , the same as allotype, 24--26 Nov. $1955 ; 1$, the same as holotype, 4 Nov. 1959. Aestival form-1 o, the same as holotype, 4 Nov. 1959 (H. Kuroko).

Distribution : Japan (Kyushu, Yakushima).

This new species is allied to Lyonetia anthemopa Meyrick, but differs from it in having an apical pencil in apical cilia of the forewing.

\section{Biological notes}

Host plant : MrricaceaE-Myricarubra Sieb. et Zucc. (Jap. name : Yamamomo). Mine: A linear-blotch mine; linear portion brown; blotch portion whitish to whitish-green, semitransparent. The earliest linear mine reaches midrib and extends towards the apex of the leaf through the midrib. Before long, the larva mines from the midrib into the mesophyll near the apex of the leaf in an irregular blotch. The blackish frasses are scattered in the blotch mine.

Development : The larvae were collected at the middle of October on Mt. Kaimon, Kyushu, and at the beginning of November on Yakushima, Satsunan Isls., and the adults emerged from the beginning to the end of November.

Lyonetia (Lyonetiola) euryella sp. nov.

(P1. 1, figs. 8a \& 8b; P1. 6, fig. 40 ; P1. 12, fig. 60; P1. 16, fig. S0)

Lyone tiu sp., Miyoshi, 1923, Byōchūgai Zasshi, 10 (9/10): 493-497.

Lyonetia sp. ?, Kobayashi, 1923, Byōchügai Zasshi, 10 (12) : 554-555.

今̊. 8-10 mm. Head, face, tuft and thorax shining white. Labial palpi white, pale greyish-fuscous externally. Antennae $11 / 2$ of forewing; greyish-fuscous, becoming paler towards base; eyecap shining white. Posterior legs white ; tarsal joints annurated with black. Abdomen pale greyish-fuscous above, shining white below.

Forewings silvery-white, costal edge greyish; streaks greyish-fuscous, 1st costal and 1st dorsal streaks absent, 2nd costal streak from 3/-1, 2nd dorsal streak from $2 / 3$, 3rd dorsal streak from beyond it, all streaks broad and converging at disc of $4 / 5$; a yellow-orange apical blotch occupying apical $1 / 5$ of wing; blackish fringe on termen; costal and terminal cilia white, 3 rather broad perpendicular blackish strigulae in costal cilia, a blackish strigula from end of apical patch in terminal cilia ; a triangular black apical dot at apex; apical and dorsal cilia greyish-fuscous. Hindwings and cilia greyish-fuscous. Underside fuscous, costal and terminal cilia white, costal strigulae distinct. 
The spring specimens have the 2nd costal and 2nd dorsal streaks broader than those of the summer one, and the color of these streaks is somewhat diffusing internally.

Southern race : $\left\{\begin{array}{r}o \\ \text {. }\end{array} 6.5-7 \mathrm{~mm}\right.$. This race differs from the former in the following characters :

1. Rather small. Antennae pale greyish-fuscous, becoming white towards base.

2. Forewing with a fuscous or pale fusocus patch from near base to middle on dorsal half, outer border of the patch oblique; markings on apical area rather pale, 2nd costal streak slender and indistinct, faint 1st costal streak appears before it.

3. Hindwings and cilia much paler.

4. Underside of forewings whitish, becoming pale fuscous towards base.

Male genitalia : Sclerotized ridge of 8th tergite rather short, anterior edge transversely straight; superuncus forming 2 broad lobes; anus surrounded by a pair of sclerotized slender arms; gnathos consists of 2 sclerotized arms, curved upwardly, apices with a shallow indention; valvae nearly rectangular, fused together in basal half ; saccus undeveloped; aedoeagus cylindrical, apex obtuse, with a few scobinations, vesica armed with some longitudinal spinous cornuti.

Female genitalia: Genital plate with an arcuated sclerotized anterior band; lamella antevaginalis triangular; ostium bursae slender; ductus bursae slender, rather long, with a weakly sclerotized small patch near inception of ductus seminalis ; corpus bursae oblong, with 2 long triangular signa, inner edges of which are irregularly dentate.

Holotype: 今, Mt. Hikosan, Fukuoka Pref., Kyushu, 21 June 1955 (H. Kuroko).

Allotype: o, the same as holotype, 3 May 1954 (H. Kuroko).

Paratypes : 3소, 3 우의, the same as holotype, 2-11 May 1954; 2 令占, 28 June

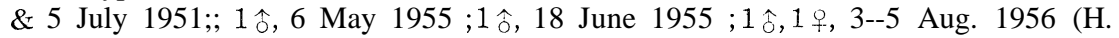
Kuroko). Southern race-1?, Mt. Kaimon, Kagoshima Pref., Kyushu, 12 Dec. 1955 ; 5 우, Cape Sata, Kagoshima Pref., Kyushu, 24 Oct.--3 Nov. 1956; 1 우, Ambō, Yakushima, Satsunan Isls., 6 Nov. 1959 (H. Kuroko).

Distribution : Japan (Honshu, Kyushu, Yakushima).

This new species is distinguishable from Lyonetialedi Wocke, 1859, by the absence of apical pencil and apical transverse line.

\section{Biological notes}

Host plants: Theaceas-Eurya japonica Thunb. (Jap. name :Hisakaki), E. emarginata (Thunb.) Makino (Jap. name : Hama-hisakaki).

Mine: An irregular linear-blotch mine, blotch portion with some constrictions, somewhat fetus-shaped ; upper surface mine ; early mined portion dark yelloworange margined with dark purplish-brown, freshly mined portion yellowish-brown to yellowish-green ; feeding area being $228-413 \mathrm{~mm}^{2}$; mine of southern race much smaller. The mine extends towards the apex of the leaf along the margin and turns near the apex and returns towards the base along the other margin. 
The 1st instar larva leaves the dark greenish frasses in the mine, but the 2nd to the 4th instar larvae make $1,2-3,4$ semicircular holes respectively on the lower side of the mine and the larval frasses are ejected from these holes, but sometimes some frasses are left in the mine. The larva does not migrate from one leaf to another. When full fed, the larva quits its mine and spins a hammock-like cocoon on the lower side of the leaf. One mine is found on a single leaf.

Development : There are 4 broods in a year on Mt. Hikosan. The larvae occur from at the end of May to the beginning of June, from the end of June to the end of July, from the middle of August to the middle of September and at the beginning of November; the larvae of the last brood hibernate at the th instar (the last instar) and pupate from the middle of March to the end of April. The adults appear from the beginning to the middle of May, from the middle of June to the beginning of July, from the end of July to the beginning of August and frorn the beginning of September to the beginning of October.

\section{Subgenus Lyonetia Huebner s. str.}

Lyonetia Huebner, [1825], Verz. bekannt. Schmett., (27): 423.

Type species : Tineaclerkella Linnaeus, 1758.

Antennae 1-1 $1 / 3$ of forewing; forewings vein 3 absent; hindwings 4 absent; superuncus with 2 narrow and rather sclerotized arms; arms of gnathos fused together or approximated distally.

kyonetia (Eyonetia) boehmeriella sp. nov.

(P1. 1, fig. 7; P1. 7, fig. 42 ; P1.12, fig. 61; P1. 16, fig. 79)

ôㅇ. 6-7 mm. Head and thorax bronzy-grey, with leaden reflections; face silvery-grey ; tuft black. Labial palpi whitish, terminal joint dark towards apex. Antennae 1 1/3, dark grey ; eyecap silvery-white, mixed with some greyish scales along margin. Posterior tibiae whitish-grey, hairs dark grey ; tarsi greyishfuscous. Abdomen bronzy-grey above, pale grey below.

Forewings bronzy-grey, with leaden reflections ; a triangular apical blotch coppery-yellow, occupying apical $1 / 4$ of wing; termen with a fringe of blackish hairs; costal and terminal cilia white, 3 blackish strigulae in costal cilia, a slightly curved strigula from end of apical blotch in terminal cilia; a round apical dot black, moderate, followed by a blackish transverse line; dorsal cilia greyish-fuscous. Hindwings and cilia greyish-fuscous.

Male genitalia : Sclerotized ridge on 8th tergite neariy rounded at anterior edge; arms of superuncus placed at a short distance from each other, broadened exceptionally, distal end nearly rounded, inner part rather sclerotized; arms of gnathos fused together, strongly sclerotized, but distal part bifid, apices shallowly concave; valvae rectangular, fused together in basal half; aedoeagus sinuous cylindrical, slightly tapered towards apex, apex truncate. 
Female genitalia : Genital plate with a sclerotized narrow transverse band; ostium bursae large, round, with a narrow strongly sclerotized anterior edge; ductus bursae broad and very short, posterior half slightly broadened and weakly sclerotized, anterior part narrower than the posterior and membranous; corpus bursae long elliptical, without a Signum.

Holotype :令, Mt. Hikosan, Fukuoka Pref., Kyushu, 9 May 1956 (H. Kuroko).

Allotype: + , the same as holotype, 21 Apr. 1954 (H. Kuroko).

Paratypes : 1今, 3 웅, the same as holotype, 28-30 June 1954; 1 令, 2 우, 22

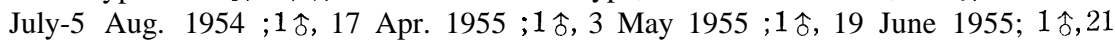
July $1955 ; 1$ ㅇ, 10 May 1956 (H. Kuroko).

Distribution : Japan (Kyushu).

This new species is separable from Lyonetia leurodes Meyrick, 1915, of Ceylon in having the apical transverse line and the yellowish apical blotch in the forewing. Leurodes has an apical pencil instead of the apical transverse line.

\section{Biological notes}

Host plants : URticaceaf-Boehmeria spicata (Thunb.) Thunb. (Jap. name :Koakaso), B.nipononivea Koidz. (Jap. name : Karamushi).

Egg: Usually deposited into the mesophyll near the apex of the leaf of the host plant through the lower cuticle.

Mine: A blotch mine; usually extends from the apex of the leaf towards the base in an irregular blotch. The spring mine is deep brown, opaque, occupying the apical portion of the leaf, while the autumnal mine is pale green, semitransparent, sometimes forming at the central portion of the leaf; feeding area being 180-234 mm? The blackish grains of frasses are scattered in the mine, but in the last instar often the frasses are ejected through a few hole which are prepared on the lower side of the mine. The larva is able to migrate easily from one leaf to another. When full fed, the larva creeps out from its mine and spins a hammock-like cocoon on the lower side of the leaf. Usually 1 larva is occupying a single mine, but sometimes 2 larvae are found.

Development : Several broods in a year on Mt. Hikosan. The larvae may be found feeding from the middle of May to the middle of June, from the beginning to the end of July, at the middle of August, from the middle to the end of September and from the beginning to the end of October. The larvae of the last brood pupate at the end of October and hibernate in the pupal stage. The adults appear from the middle of April to the middle of May, from the end of June to the beginning of July, from the end of July to the beginning of August, at the end of August and at the middle of October.

\section{Lyonetia (Lyonetia) ledi Wocke}

(Pl. 1, figs. 6a \& 6b; Pl. 8, fig. 43; Pi. 12, fig. 62; Pl. 15, fig. 78)

Lyonetia ledi Wocke, 1859, Jhrsb. Schles. Ges., 1859: 101; Rebel, 1901, Cat. Lep. 
Pal., 2: 217, no. 4218; Spuler, 1910, Schmett. Europ., 2 : 422; Orstadius, 1918, Ent. Tidskr., 39 : 76, f. 7.

Lyonetia candida Braun, 1916, Canad. Ent., 48 : 140, syn. nov.

$\hat{0}$ ․ 7-8 mm. Head, tuft, face and thorax shining, white. Labial palpi whitish tinged with pale fuscous externally. Antennae $11 / 3$ of forewing; pale fuscous, becoming white towards base; eyecap shining white. Posterior legs whitish; tarsal joints annulated with black. Abdomen greyish-fuscous above, shining white below.

Forewings shining white, costa margined with greyish-fuscous faintly ; streaks rather broad and dark grey, 1st costal and 1st dorsal streaks absent, 2nd costal streak from $2 / 3$, 2nd dorsal streak from $3 / 4$, and 3 rd dorsal streak from tornus, these streaks converging in disc of $3 / 4$; a yellow-orange apical blotch occupying apical $1 / 4$ of wing, with a blackish fringe on termen, outer margin sinuated; costal and terminal cilia white, 3 blackish strigulae in costal cilia, a straight blackish strigura from end of apical blotch in terminal cilia, black apical dot rather large, followed by a transverse line and an apical pencil, dorsal cilia pale fuscous. Hindwings fuscous ; cilia pale fuscous.

Northern race: This race differs from the former in the following characters. Forewings with yellowish-fuscous 1st costal and 1st dorsal streaks, the former shortly before 2nd costal streak, the latter from before middle of dorsum, very broad, interrupted or constricted on fold; a fuscous dot above dorsum at $1 / 5$.

Male genitalia : Sclerotized ridge on 8th tergite narrow and pointed; arms of superuncus placed at a short distance from each other, with each base broadened, tapered distally, pointed ; arms of gnathos not fused, rather long protruded, upwardly or inwardly curved, apices slightly splitted; valvae oblong, cuculus protruded ; saccus triangularly pointed ; aedoeagus stout, tapered towards apex, apex incised and 2 pionted.

Female genitalia : Genital plate sclerotized, with a narrow sclerotized anterior band; ostium bursae broad and large, cup-shaped; ductus bursae broad, slightly sclerotized and reticulated in posterior $2 / 3$, anterior $1 / 3$ membranous, somewhat narrower than the posterior; ductus seminalis opening into corpus bursae; corpus bursae rounded, without signum.

Specimens examined : 1令, 2 오, Mt. Hikosan, Fukuoka Pref., Kyushu, 2 Aug. 1954; 1소, 24 June 195う; 3 令令, 6 웅, 28 June-47 July 1957 ; 1 우, 26 Aug. 1962 (H. Kuroko). Northern race-1 令, Aizankei, Hokkaido, 3 Aug. 1957 (T. Kumata), bred

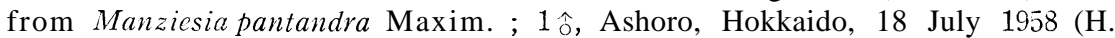
Kuroko), bred from Rhododendrondauricum Linn.; 1今, Kamikochi, Nagano Pref., Honshu, 23 Sept. 1963 (H. Kuroko), bred from Rhododendron japonicum (A. Grey) Suringer.

Distribution : Japan (Hokkaido, Honshu, Kyushu), Europe, N. W. Kussia, N. America (California).

This species has been unrecorded from Japan. The specific name of Japan ese specimens was determined in comparison with the type specimens of Wocke by 
Dr. K. Sattler and the synonymic name was proved in comparison with the type specimens of Braun by Dr. J. F. Gate Clarke. Later, I was favored with an opportunity to confirm the specific name of our species through examining of the European specimens sent by Dr. Sattler.

\section{Biological notes}

Host plants : ERICACEAE-Rhododendron dauricum Linn. (Jap. name : Ezo-murasaki-tsutsuji), R. mucronulatum Turcz. var. ciliatum Nakai (Jap. name :Genkai. tsutsuji), R. Kaempferi Planch. (Jap. name : Yama-tsutsuji), R. japonicum (A. Gray) Suringer (Jap. name : Renge-tsutsu ji), Menziesia pentandra Maxim. (Jap. name : Ky-yoraku-tsutsuji), in Japan. ERICACEAE-Rhododendronoccidental Gray., $R$. albirlorum Hook, in N. America. Ericaceat-Ledum palustre Linn.; MyricaCEAE-Myrica gale, in Europe.

Mine: A linear-blotch mine ; linear portion brownish, sometimes margined with purplish brown, blackish frasses arranged in a central line, 20-40 mm, in length; blotch portion pale green to pale greenish-brown, full-depth type, $100-$ $130 \mathrm{~mm}^{2}$. in area. The linear mine extends along the margin of the leaf towards apex and expands to blotch on apical portion of the leaf. Along the border of the blotch portion of the mine on the lower side, the larva makes a few semicircular slits through which the larval frasses are ejected, but often some frasses are contained in the mine. The larva migrates easily from one leaf to another. When full fed, the larva quits the mine and spins a hammock-like cocoon on the lower side of the leaf. One mine is found on a single leaf.

Development : The number of generation is unknown, but the larvae were collected from the beginning to the end of June and from the middle to the end of July on Mt. Hikosan, and the adults appeared from the end of June to the middle of July and from the end of July to the beginning of August.

Lyonetia (Lyonetia) prunifoliella malinella (Matsumura), comb. nov. (Pl. 1, figs. 5a \& 5b; Pl. 7, fig. 41; Pl. 17, fig. 63)

Lithocollctis malivorella Matsumura, 1906, Nippon Gaichū Mokuroku :25(nomen nudum); id., 1910, Dainihon Gaichū Zensho, 1: 154; id., 1920, Gaichū Zensho, $1: 431$, syn. nov.

Lithcolletes (sic) malinella Matsumura, 1907, Konchū Bunruigaku, 1: 204, f. 237.

Lyoneta (sic) malivorella Matsumura, 1931, 6000 Ill. Ins. Jap. : 1105, no. 2307 ; id., 1932, Ins. Mats., 6 (4): 200 (n. sp.).

Lyoneta (sic) ringoniella Matsumura, 1931, 6000 Ill. Ins. Jap. : 1106, no 2309 ; id., 1932, Ins. Mats., 6 (4): 200 (n. sp.), syn. nov.

Lyonetia prunifoliella: Issiki, 1932, in Icon. Ins. Jap., (ed. 1): 1481, f. 2932 ; id., 1950, (ed. 2): 445, f. 1197; Inoue, 1954, Check List Lep. Jap., Part 1: 24; Issiki, 1957, in Icon. Met. Jap. Col. Nat., 1: 19, pl. 2, f. 60; Okano, 1959, in Icon, Ins.. Jap. Col. Nat., 1: 276, pl. 182, f. 24.

f. ringoniclla Matsumura (aestival form): $\hat{o}+$. $8 \mathrm{~mm}$. Head, tuft, face and thorax shining white. Labial palpi whitish tinged with pale fuscous externally, 
Antennae $11 / 4$ of forewing; greyish-fuscous, becoming white towards base ; eyecap shining white. Posterior legs whitish; tarsal joints ringed with black. Abdomen greyish-fuscous above, shining white below.

Forewings shining white, costal margin greyish-fuscous ; streaks greyish-fuscous, 1st costal streak from $2 / 3$, 2nd costal streak from 3/4, 1st dorsal streak from middle, very oblique and slightly arcuated, 2nd dosal streak from $3 / 4$, and 3rd dorsal streak from beyond it, all streaks converging in disc of $5 / 6$; a yelloworange apical blotch occupying apical $1 / 6$ of wing, with a blackish fringe on termen; costal and terminal cilia white, 3 perpendicular blackish strigulae in costal cilia, a slightly curved blackish strigula from end of apical blotch in terminal cilia; a rather large black apical dot followed by a blackish transverse line and an apical pencil; dorsal cilia greyish-fuscous. Hindwings and cilia greyish-fuscous.

f. malinella Matsumura (autumnal form) : $\hat{\delta}$ ㅇ. $10 \mathrm{~mm}$. Head and fillet shining white; face fuscous ; tuft mixed with black hairs, except behind. Antennae dark fuscous ; eyecap whitish. Thorax whitish, anterior $1 / 2$ blackish, and with a black spot posteriorly. Posterior tibiae dirty white with greyish hairs above; tarsi greyish, banded with black. Abdomen greyish-fuscous above, shining white below.

Forewings elongated ; costal half blackish-fuscous, sometimes suffused with pale greyish-fuscous, dorsal half white with a few brownish scales, broad and short blackish protrusions beyond fold in dorsal half near base and at $1 / 3$; blackish 1st dorsal streak very broad, with some pale grey and pale brown scales near dorsum, very broad 2 nd and 3rd dorsal streaks blackish-grey with some brown scales, 1st and 2nd costal streaks pale greyish-fuscous obscurely, between these with some whitish scales; apical blotch brownish-yellow, with some blackish scales on dorsal half.

Male genitalia : Sclerotized ridge on 8th tergite with a concave anterior edge; arms of superuncus placed at a short distance from each other, with each base broadened, angulated outwardly, tapered towards apex, apex curved inwardly ; arms of gnathos fused together, apex with 3 pairs of projections, posterior projections rounded, anterior 2 pairs pointed ; valvae oblong; saccus slenderly projected, pointed ; aedoeagus rather stout, tapered towards apex, apex truncate.

Female genitalia : Genital plate triangular, with a narrow strongly bended sclerotized anterior band; ostium bursae membranous, opening near anterior edge of genital plate; ductus bursae with a T-shaped sclerotized plate at middle; corpus bursae without Signum.

Specimens examined : f. ringoniella Matsumura-1 $q$ (holotype of Lyonetia ringoniella), Sapporo, Hokkaido, 30 June 1909 (Arakawa); 1\}, 2 우, Sapporo, (M. Matsumura), in Coll. Hokkaido University. $6 \hat{\jmath}$ 令, 5 우우, Fukushima City, Fukushima Pref., Honshu, 31 Aug.-2 Sept. 1958 (M. Kumakura); 4 占, 1 오, Sapporo, 11 Sept. 1958 (T. Kumata). f. malinella Matsumura-1 今 (holotype of Lyonetia malivorella, without abdomen), Sapporo, (M. Matsumura); 5 exs., Sapporo, 14 Oct. 1908 (Arakawa), in Coll. Hokkaido University. 5今ో, 5 우, Fukushima City, 10-16 Oct. 1958 (M. Kumakura). 
Distribution : Japan (Hokkaido, Honshu).

This subspecific name was newly combined through comparison of the genitalia of prunifoliella Huebner with those of malinella Matsumura.

This subspecies differs from the nominate race of Europe in the following characters :

1. Aestival form: First dorsal streak of forewing raising from middle of dorsum in malinella; that of prunifoliella from near $2 / 5$ and broadened towards dorsum.

2. Autumnal form: Costa1 half of forewing blackish in malinella; costal half whitish and obliquely black-spotted on dorsal half in prunifoliclla (f. padifoliclla Huebner).

\section{Biological notes}

Host plants : RosaCzas-Malus pumila Mill (Jap. name : Seiyo-ringo), M.sie-

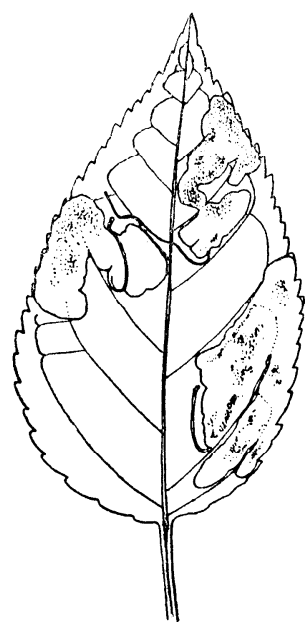

Fig. 2. Leaf of Malus pumila Mill with linear-blotch mines of Lyonetia prunifoliella malinella (Matsumura). boldii (Regel) Rehder (Jap. name :Zumi).

The nominate race is said mining in the leaves of Prunus, Cotoneaster, Crataegus, Mespilus, Cydonia, Betula, and so on.

Mine: A linear-blotch mine; linear portion brown, dark brown frasses arranged along the centre of the mine, $16-20 \mathrm{~mm}$. in length, blotch portion pale greenish brown, 95-103 mm. ${ }^{2}$ in area. The linear portion of the mine extending towards the margin of the leaf, sometimes crossing the midrib; the mine shortly later abruptly broadened and forming an irregular blotch along the margin of the leaf. On the lower surface of the blotch mine the larva prepares a few slits from which the frasses are ejected, but some frasses are scattered in the mine. Afterward, the upper epidermis of the border of the mine is detached from the vital tissue surrounding the mine. One to several mines are found on a single leaf.

\section{Lyonetia (Lyonetia) anthemopa Meyrick}

(Pl. 1, figs. 4a \& $4 \mathrm{~b} ; \mathrm{Pl}$. 3, fig. 27; P1. 8, fig. 44 ; PP. 13, fig. 67; P1. 15, figs. 76 \& 77)

Lyonetia anthemopa Meyrick, 1936, Exot. Microlep., 5: 58 ; Kuroko, 1961, Pub., Ent. Lab., Univ., Osaka Pref., No. 6 :17-22, pls. 2 \& 17.

Aestival form : $\$+.5-6.5 \mathrm{~mm}$. Head, face, tuft and thorax shining white. Labial palpi whitish tinged with pale fuscous externally. Antennae $11 / 3$ of 
forewing; pale greyish-fuscous, becoming white towards base: eyecap shining white, Posterior legs whitish; 1st and 2nd tarsal joints annulated with greyishblack, others wholly greyish-black. Abdomen pale greyish-fuscous above, white below.

Forewings shining white ; costal area shaded with obscurely pale greyish; each streak greyish-fuscous, 1st costal streak from middle of costa, 2nd costal streak from 2/3, 1st dorsal streak from before middle of dorsum, 2nd dorsal streak from $2 / 3$ and $3 \mathrm{rd}$ one from $4 / 5$, all the streaks almost converging at disc of $3 / 4$; a yellow-orange apical blotch occupying apical $1 / 5$ of wing, with a blackish fringe on termen; costal and terminal cilia white, 3 greyish-fuscous strigulae in costal cilia, a greyish-fuscous curved strigula from end of apical blotch in terminal cilia ; at apex a round black apical dot followed by a greyish$\mathrm{f}$ uscous transverse line; dorsal cilia pale greyish-fuscous. Hindwings greyishfuscous ; cilia pale greyish-fuscous.

Autumnal form : 令实. 7--8 mm. Head, thorax dark fuscous with purplish reflections, tuft fuscous, filet whitish, face and labial palpi more or less tinged with fuscous. Antennae dark greyish-fuscous ; eyecap pale fuscous. Posterior legs pale greyish-fuscous, tarsi annulated with greyish-black, apical 3 joints greyish-black. Abdomen of the same color as aestival form.

Forewings more elongated than those of aestival form; pale greyish-fuscous; dorsal and costal streaks indistinct, dorsal half fuscous, sometimes with purplish reflections, with some whitish scales along fold; yellow-orange apical blotch mixed with some greyish scales. Hindwings and cilia of the same color as the above form.

In the pale specimen, dorsal half of the forewing as pale greyish-fuscous as the costal half; dorsal and costal streaks present, 1st dorsal streak broadened in dorsal area; an additional dark fuscous patch present from base to $1 / 4$ on dorsal half, and its distal margin oblique, parallel with 1st dorsal streak.

Male genitalia : Longitudinal sclerotized ridge on 8th tergite furcate at anterior end; arms of superuncus with a broad base, tapered towards apex, curved inwardly, placed at a distance from each other; arms of gnathos fused together, apex with 2 pairs of projections, the outer pointed upwardly, the inner rather rounded ; valvae very weak and oblong; saccus short, pointed triangularly ; aedoeagus tubular and upper edge of the apical portion slightly extended posteriorly.

Female genitalia : Genital plate with a broad sclerotized anterior band, lamellae vaginales sclerotized, very slender, and placed near posterior edge of the anterior band; ductus bursae slender, a Signum-like plate near juncture with corpus bursae ; corpus bursae rather small, narrow, and scattered with minute spines, without signum.

Specimens examined : Aestival form-1 $\hat{\delta}$, Taihoku, Formosa, 20 May 1935 (S. Issiki); $1 \hat{\circ}, 3$ 우우, in campus of Kyushu Univ., Fukuoka Pref., Kyushu, 17-19 Sept. 1955; 8 ㅅํㅇ, 10 우우, 28 July-2 Aug. 1957 ;3 우아, 16-19 June 1958 (H. Kuroko). Intermediate form-1 + , the same as the above locality, 29 Sept. 1957 (H. Kuroko). Autumnal form-5 소, 5 우, the same as the above locality, 12-21 Oct. 1956; 
4朎, 3 웅, Ambō, Yakushima, Satsunan Isls., 2-9 Nov. 1959 (H. Kuroko).

Distribution : Japan (Honshu, Kyushu, Yakushima), Formosa.:

\section{Biological notes}

Host plants : RosACEAE-Pyracantha angustifolia Schneider (Jap. name :Tachibana-modoki), P. crenūrata Roem., Raphiolepis umbellata (Thunb.) Makino (Jap. name: Sharinbai), in Japan. RosaCeAe-Photiniataiwanensis Hay. (Jap. name : Taiwan-kanamemochi) in Formosa.

Egg: The egg is deposited into the mesophyll of the leaf of the host plant through the lower cuticle which is between two of the side ribs.

Mine: A linear-blotch mine. Newly hatched larva mines in a linear and full-depth mine, reaching the leaf margin and extending towards the tip of the leaf along the margin; the mine becomes slightly broadened after the 1 st moult; the linear mine is brown or pale brown in color, as the brownish grains of frasses are filled. After the 2nd moult, the mine extends in blotch and its color is pale greenish-brown, because the brownish grains of frasses are contained. The larva often mines in an unopened leaflet and the leaflet changes to dead-leaf color by the exhaustion of leaf tissues. If the leaf-size is not enough to complete the larval growth, the larva leaves the empty leaf and migrates to another leaf through the lower surface. The linear mines are $15-22 \mathrm{~mm}$. in length and the blotch mines $83-121 \mathrm{~mm}$ ? in area. After leaving the mine, the mature larva walks just like a looper.

Development : Four broods in a year at Fukuoka, North Kyushu. The larvae of the 1st generation occur from the end of May to the beginning of June, and the adults appear from the middle of June to the beginning of July. The larvae of the next generation occur at the middle of July and the adults from the end of July to the beginning of August. The larvae of the 3rd generation at the middle of August and the adults from the beginning to the middle of September. The larvae of the last generation occur at the middle of September and the adults from the middle to the end of October. The adults of the last generation are of autumnal form and are through to hibernate. It is of interest to the record here that one female adult appeared on Sept. 29th, 1957, showing an intermediate coloration. On Yakushima, the larvae were collected at the end of October and the adults of autumnal form appeared at the beginning of November.

\section{Lyonetia (Lyonetia) yasudai sp. nov.}

(Pl. 1, fig. 3; P1. 8, fig. 45 ;Pl. 13, fig. 66)

ô + . $6.5-7 \mathrm{~mm}$. Head, tuft, face and thorax shining white. Labial palpi whitish with pale fuscous externally. Antennae $11 / 3$ of forewing; dark fuscous, becoming white towards base ; eyecap shining white. Posterior legs white; tarsi with blackish points. Abdomen greyish-fuscous above, shining white below.

Forewings shining white; a slightly oblique oval yellow-orange discal blotch 
from dorsum at $1 / Z$ to disc at $3 / 4$, not reaching costal margin, margined with dark fuscous ; a pale fuscous vertical streak (2nd costal streak) from end of discal blotch to costa; an apical blotch yellow-orange, with a blackish fringe on termen; costal and terminal cilia white; 3 blackish strigulae in costal cilia, middle one outwardly-oblique ; a blackish strigula from end of apical blotch in terminal cilia ; a black apical dot with a short blackish transverse line in costal cilia, and followed by a blackish pencil; a blackish dorso-apical line from its base; dorsal cilia pale fuscous. Hindwings fuscous ; cilia pale fuscous.

Male genitalia: Sclerotized ridge on 8 th tergite short, furcate at anterior end; arms of superuncus adjacent to each other at base, distal end obtuse, not tapered ; arms of gnathos triangular, pointed upwardly; valvae oblong; saccus rather long, pointed; aedoeagus broadened basal half, apical half narrower, cylindrical, slightly curved, with some inverse spines ventrally.

Female genitalia: Genital plate narrowly longitudinally sclerotized, with a narrow bent sclerotized anterior band; ostium bursae membranous, small, round; ductus bursae with 2 small weakly sclerotized patches at middle; corpus bursae moderately long, minutely scobinated; signa rather long (half length of corpus bursae), symmetrical, slender, horn-shaped with a long spine.

Holotype: 今̂, Mt. Nachi, Wakayama Pref., Honshu, 10 June 1957 (T. Yasuda), Allotype: + , the same as holotype.

Paratypes: 3송, 7 우, the same as holotype, 10 \& 11 June 1957 (T. Yasuda).

Distribution : Japan (Honshu).

This new species is very close to L. bakuchia (following species), but distinguishable from it in the following characters:

1. The 2 nd costal streak of the forewing is pale fuscous in yasudai; pale yellow in bakuchia.

2. The discal blotch of yasudai is slightly smaller than that of bakuchia, and lacks whitish scales towards the tornus.

3. The middle strigula in the costal cilia oblique outwardly in yasudai; that of bakuchia is perpendicular.

\section{Biological notes}

Host plant : FAGAcEAE-Quercus acuta Thunb. (Jap. name : Aka-gashi).

Mr. T. Yasuda informed me that the larva was mining in a linear type on the leaf of the host plant.

Lyonetia (Lyonetia) bakuchia sp. nov.

(P1. 1, fig. 2; P1. 9, fig. 47 ; P1. 13, fig. 65; P1. 15, fig. 75)

今우. 7-7.5 mm. Head, tuft, face, labial palpi and thorax shining white. Antennae $11 / 3$ of forewing; dark fuscous, becoming white towards base; eyecap shining white. Posterior legs white; tarsal joints ringed with blackish. Abdomen greyish-fuscous above, shining white below. 
Forewings shining white; dorsal and costal streaks absent, except 2nd costal streak colored with pale yellow indistinctly; an oblique yellow-orange discal blotch from just before middle of dorsum to disc at $3 / 4$, slightly warped elliptical not reaching costal margin, margined with dark fuscous, along dorsum whitish towards tornus; an apical blotch yellow-orange, with a blackish fringe on termen; costal and terminal cilia white; 3 perpendicular strigulae in costal cilia, 1st yellowish, others blackish, becoming yellow-orange towards bases; a blackish straight strigula from end of apical blotch in terminal cilia; an apical dot black, with a short blackish line in costal cilia, and followed by a blackish pencil, a blackish dorso-apical line from its base; dorsal cilia pale fuscous. Hindwings fuscous; cilia pale fuscous.

Male genitalia : Sclerotized ridge on 8th tergite short, shortly furcate at anterior end; arms of superuncus rather broad basally, distal end of sclerotized portion inwardly-curved, pointed ; arms of gnathos approximated, triangular, apices elongated, sclerotized, not pointed; valvae oblong; saccus rather short, triangularly pointed ; aedoeagus rather short cylindrical, tapered towards apex, apex slightly furcate.

Female genitalia: Genital plate longitudinally sclerotized, with a narrow bent sclerotized anterior band; ostium bursae membranous, round; ductus bursae rather slender, with a small sclerotized patch near ostium; corpus bursae moderately long, minutelly scobinated; signa as in yasudai, with a long spine, but asymmetrical.

Holotype : 今, Cape Sata, Kagoshima Pref. Kyushu, 26 Oct. 1956 (H. Kuroko . Allotype: + , the same as holotype.

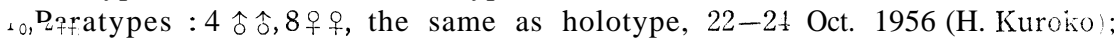
Satsunan12 $q q$, Isls., Cape 20-25Sata, 22 0ct. 19591958 (H. Kuroko). (T. Yasuda); $2 \hat{\jmath} \hat{o}, 3$ 우, Issō, Yakushima, Nov:

Distribution : Japan (Kyushu, Yakushima).

This new species is allied to $\boldsymbol{L}$. penthesilea Meyrick, 1921, of Quee nsland. But in penthesilca the discal blotch is occupying apical $2 / 3$ of forewing.

\section{Biological notes}

Host plant. Rosacear-Prunus Zippeliana Miq. (Jap. name : Bakuchinoki).

Mine: A linear mine, upper surface type; yellowish-brown to pale greenishbrown, blackish-brown frasses arranged in a rather broad central line; 110-120 $\mathrm{mm}$. in length. The mine is usually found on the young leaf; it commences near margin of the leaf and extends in an irregular serpentine or tortuous gallery. The larva migrates easily from one leaf to another. When full fed, the larva splits the upper epidermis of the leaf, and creeps out. One to several mines are found on a single leaf.

Development : The larvae were collected at the middle of October, at Cape Sata and at the beginning of November on Yakushima. These larvae pupated from the end of October to the middle of November and the adults appeared from the end of October to the end of November. 


\section{Lyonetia (Lyonetia) clerkella (Linnaeus)}

(P1. 1, fig. 1; Pl. 9, fig. 41; PI. 13, fig. 64; P1. 14, fig. 74)

Tinca clerkella Linnaeus, 1758, Syst. Nat., (ed. 10):542; id., 1761, Fauna Svecia : 303 ; id., 1767, Syst. Nat., (ed. 12) : 899.

? Tinea cerasifoliella Huebner, 1816, Samm. europ. Schmett., f. 190.

? Tinea malifoliella Huebner, 1816, Samm. europ. Schmett., f. 195.

Lyonctia clerkella: Huebner, [1825], Ver. bekannt. Schmett., (27): 423 ;Zeller, 1839, Isis (Oken), 1839 : 216; id., 1848, Linn. Ent., 3 :252; Meyrick, 1895, Hand. Brit. Lep. : 757 ; Rebel, 1901, in Staudinger-Rebel, Cat. Lep. Pal., 2: 217; Spuler, 1910, Schmett. Europ., 2: 422; Trägårdh, 1910, Entom. Tidskr., 31: 266-270; Kuwana \& Takachiho, 1911, Rep. Imp. Agr. Exp. Sta., Tokyo, No. 38: 99-102, pl. 6, ff. 5-9 ; Kemner, 1926, Medd. Centr. Anst. försöks Ent. Avdeln, 28 : 1-59; Meyrick, 1929, Rev. Hand. Brit, Lep.: 811; Issiki, 1932, in Icon. Ins. Jap., (ed, 1):1482, f. 2933 ; Meyrick, 1933, Exot. Microlep., 4:365; Fletcher, 1933, Scient. Monogr. Imp. Counc. Agr. Res., 4: 69; Pierce \& Metcalfe, 1935, Genitalia Tin. Fam. Lep. Brit. Is. : 89, pl. 55; Issiki, 1950, in Icon. Ins. Jap., (ed. 2): 444, f. 1196; innue, 1954, Check List Lep. Jap., Part 1: 24; Paulian \& Viette,, 1955,

Mém, l'Inst. Sci. Madagascar, Ser. E, 6 ; 150, f. 6: Kuroko, 1957, Enum. Ins. Mont. Hikosan, 1. Lep. : 2; Issiki 1957, in Icon. Het. Jap. Col. Nat., 1; 19, pl. 3,f. 61; Okano, 1959, in Icon. Ins.' Jap. Col. Nat., 1: 276, pl. 182, f. 23.

Lyonetia cerasifoliclla: Huebner, [1825], Ver. bekannt. Schmett., (27): 423.

Lyonetia malifoliella: Huebner, [1825], Ver. bekannt. Schmett., (27): 423.

Hcribeïaunipunctella Stephens, 1829, Sist. Cat. Brit. Ins., 7327.

Elachista clcrkella Treitschke, 1833, Schmett. Europa, 9 (2): 191.

Eiachista acreella Treitschke, 1833, Schmett. Europa, 9 (2): 192.

? Argyromyges autumnella Stephens, 1835, Ill. Brit. Ent., 3: 260.

(Momono-senyōch̄̄), Sasaki, 1903, Dobutugaku Zassi,no. 181: 381-383.

Tischcria ?, Sasaki, 1905, Kaju Gaichū-hen:56-58.

Lyonctia sp., Harukawa \& Yagi, 1918, Ber. Ohara-Inst., 1 (3): 335 348, 1 pl.

Aestival form : $\{$ ․ $6-7 \mathrm{~mm}$. Head tuft, face, labial palpi and thorax shining white. Antennae $111 / 4$ of forewing; pale fuscous, becoming white towards base; eyecap white. Posterior legs white; tarsi tinged with greyish-fuscous above. Abdomen whitish, sometimes grey above.

Forewings shining white; a yellow-orange oval discal blotch from $3 / 5$ to $4 / 5$ above fold, margined with fuscous : 1stcostal and 1st dorsal streak absent, 2nd costal streak from $3 / 4$, 2nd dorsal streak $4 / 5$, meeting at posterior margin of discal blotch; an apical blotch yellow-orange, with a blackish fringe on termen; costal and terminal cilia white; 3 almost perpendicular blackish strigulae in costal cilia, becoming yellowish towards bases; a dark fuscous straight strigula from end of apical blotch in terminal cilia; a round apical dot moderate, black; from it projecting a dark fuscous apical pencil; a dark fuscous dorso-apical line from its base; dorsal cilia pale fuscous. Hindwings and cilia pale fuscous.

Autumnal form : $\hat{0}$ ㅇ. $8-9 \mathrm{~mm}$. Head and thorax tinged with fuscous; tuft mixed with dark scales; face and fillet white. Antennae dark fuscous ; eyecap whitish. Abdomen pale fuscous above.

Forewings more elongate than the former; suffused with pale brown; discal 
and apical blotches darker; an oblong dark fuscous patch along fold near base. However, the specimens from Fukushima City, Honshu, which was bred from the larvae mining in the leaves of Malus pumilla Mill., subbasal patch absent and scattered by dark scales partially.

Male genitalia : Longitudinally sclerotized ridge on 8th tergite long, furcate at anterior end; arms of superuncus placed at a distance from each other, rather slender, broadened basally, pointed distally; arms of gnathos broadened triangularly, peaked at distal end; valvae weakly sclerotized, oblong, apex rounded; saccus obtuse ; aedoeagus rather slender, base rather broad and tapered towards apex, pointed, slightly curved downwards.

Female genitalia : Genital plate rather broad longitudinally sclerotized, with a sclerotized, broadened at middle, anterior band; ostium bursae tubular, membranous; ductus bursae with a weakly sclerotized small patch near juncture with corpus bursae; corpus bursae rather long, scobinated, with a thorn-shaped Signum.

Specimens examined : Aestival form-1 ㅇ, Mt. Hikosan, Fukuoka Pref., Kyushu, 13 Sept. 1954; 2 우우, 2 \& 4 Oct. 1955: 7 송, 6 우우, Ogōri, Mii-gun, Fukuoka Pref., Kyushu, 2-6 Aug. 1957 (H. Kuroko), bred from Prunus Percica (Linn.) Batsch. 4 우우, Mt. Hikosan, 22-23 June 1954 ; 1 우, 29 July 1954; 2 송, 4 \& 11 Aug. 1954; $1 \hat{\delta}, 13$ June 1955 ; 3 송, 3 우우, 11-14 July 1957 ; 2 우우, 24 Sept. 1961 (H. Kuroko), bred from Prunus Jamasakura Sieb., ex Koidz. Autumnal form-1 오. Mt. Hikosan, 19 Oct. 1954 (H. Kuroko); 1,ㅇ우우, Yoshii, Fukuoka Pref., Kyushu, 13 Oct. 1958 (N. Gybtoku), bred from Prunus Persica (Linn.) Batsch. 1令,2우, Fukushima City, Fukushima Pref., Honshu, 10-19 Oct. 1958 (M. Kumakura), bred from Malus pumila Mill.

Distribution : Japan (Honshu, Shikoku, Kyushu), Formosa, England, Ireland, N. \& C. Europe, India, Madagascar.

\section{Biological notes}

Host plants : Rosaceae-Prunus Persica (Linn.) Batsch. (Jap. name: Momo), P. Jamasakura Sieb., ex Koidz. (Jap. name: Yama-zakura), Malus pumila Mill (Jap. name : Seiyo-ringo), in Japan. Rosaceae-Prunus, Cerasus, Crataegus, Mespilus, Cydonia, Chaenomeles, Malus, Pyrus, Amelanchier, Cotoneaster,Sorbus;Moraceat-Humulus; Betulaceat-Betula; Salicachae-Salix; Fagaceae-Castanea, in Europe. Myrtaceae-Eucalyptus in Madagascar.

On Mt. Hikosan 2 biological races are recognizable within the species, viz., the peach race and the cherry race. The differences are found in the manner of mining between the 2 races and their biological notes are as follows.

Peach race : Mine of a linear type, usually along the leaf margin, and each mine running in parallel; whitish-green in color, blackish frasses arranged in a central line; the earliest mined portion circinate and surroundings of it are died and the color turned to blackish-brown ; 80-100 mm. in length. The larva does not migrate from one leaf to another. One to several mines are found on a single leaf. 
The larvae were collected on Mt. Hikosan at the beginning of June, from the beginning to the end of August and at the beginning of October, and the adults

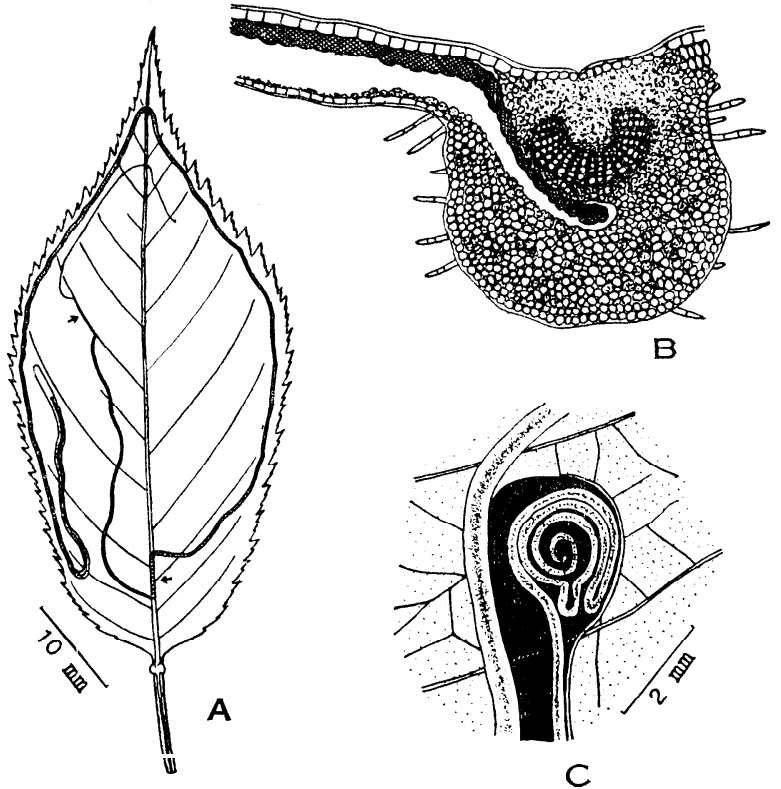

Fig. 3. Mines of Lyonctiaclerkella (Linnaeus).

A. Leaf of Prunus Jamasakura Sieb., ex Koidz. : Linear mine of a cherry race, shown 2 spots where the moulting occurred (indicated by arrows).

B. Cross-section of leaf midrib of Prunus Jamasakura, in which the 2nd moulting occurred.

C. Leaf of Prunus Pcrsica Batch. : The earliest mined portion of a peach race. Necrotic area is smeared with black.

appeared at the middle of June, from the end of August to the middle of September and at the middle of October. Some adults of the last generation were autumnal form.

Cherry race : Mine of a tortuous linear type, running along the leaf margin or irregularly; brown in color, blackish frasses arranged in a central line ; the earliest mined portion smooth without forming circinate; 138-148 $\mathrm{mm}$. in length. The larva moults in the lateral rib and midrib (the 1 st in the lateral rib and the 2nd in the midrib), therefore the mine always jointed to these ribs.

The larvae occur on Mt. Hikosan from the end of May to the end of August continuously, and the adults appear from the middle of June to the end of August. 
I have never seen the autumnal from of cherry race. At the time of egglaying, the adults of cheery race showed a strong preference to the leaves of Prunus Jamasakura Sieb., ex Koidz. and the egg is never deposited on the leaf of Prumus Peysica Batsch.

\section{Subfamily LEUCOPTERINAE}

Head rough or smooth; face smooth. Ocelli absent. Labial palpi short, drooping, or rudimentary. Maxillary palpi rudimentary. Tongue short and naked. Antennae 4/5-1 of forewing; scape dilated to form an eyecap. Mesothorax set with a long tuft on each side adjacent to base of underside of forewing. Posterior tibiae with long hairs above and below. Abdomen rather broad, armed with short spines dorsally.

Forewings broad-lanceolate, costa slightly arched, tornus more or less rounded, apex usually caudate ; a metallic-colored patch on tornus. Considerable diff erentiations are seen among genera in the venation and those are as follows; in the forewing $\mathrm{lb}$ furcate or simple, number of veins varying from 7 to 10 , and transverse vein between 2 and 5 present or absent.

Male genitalia : Eight sternite rudiment and represented by 2 developed processes ; tuba analis usually protruded ; valvae usually weak; gnathos present or absent; aedoeagus with a broad or huge bulbous base.

Female genitalia : Papillae anales rounded or pointed ; apophyses anteriores and apophyses posteriores not long; lamellae vaginales pointed or undeveloped ; signum absent.

So far as I have examined, the species included in this subfamily have undergone wide specializations in the morphorogical characters of the male genitalia and those characters are hardly relative to the similarity by the characters, such as the marking and wing venation. Therefore, it seems that the grouping by the genital characters is difficult in this subfamily.

\section{Genus Microthauma Walsingham}

(P1. 2, fig. 19)

Microthauma Walsingham, 1891, Trans. Ent. Soc. London, 1891: 127.

Type species : Microthaumametallifera Walsingham, 1891.

Kead tufted above; face smooth. Labial palpi short, drooping. Maxillary palpi rudimentary. Tongue short, naked. Antennae near 1 of forewing, 令 simple; scape forming an eyecap. Posterior tibiae clothed with long hairs above and below. Abdomen rather broad, poorly spined dorsally.

Forewings broad-lanceolate, apex protruded ; vein lb short furcate ; transverse vein present; 3 and 4 absent; 6 to dorsum near apex; 7 and 8 absent; 9 and 10 not stalked; 11 absent; ground color shining white, with some blackish streakes and a rather small metallic-colored tornal patch. Hindwings under $1 / 2$, 
narrow-lanceolate, cilia 5; transverse vein absent between 2 and 6,5 absent; shining white.

Male genitalia : Eighth sternite with 2 processes; genital ring elliptical; gnathos not separate; valvae united with aedoeagus.

Female genitalia : Genital plate with an ovate plate on each side; corpus bursae without Signum.

This genus was newly reported from Japan in this paper, and the generic name of our species was determined by Mr. Tremewam by careful comparison of the genitalia of the type (q) of Microthauma metallifera Walsingham and the figure of the genitalia of our species. This genus resembles Leucoptera in the venation, but differs from it by the length of labial palpi, and the characters of male and female genitalia given in the descriptions. The character of the cocoon shows that this genus is more related to Proleucoptera than Leucoptera.

\section{Microthauma glycinella sp. nov.}

(Pl. 1, figs. 15a \& 152; Pl. 4, fig. 28; Pl. 11, fig. 53;

Pl. 13, fig. 68 ; Pl. 17, fig. 86)

Aestival form : $\hat{\circ}$ +. 5.5-6.0 mm. Head, tuft, thorax and abdomen shining white. Labial palpi short, whitish. Antennae pale fuscous; eyecap shining white. Anterior tibiae and tarsi brown with golden reflections. Posterior legs shining white; tarsi dotted with pale fuscous on 2nd, 3rd and 4th joints.

Forewings shining white; an indistinct oblique pale fuscous streak at $1 / 5$ of dorsum, sometimes absent; an oblique rather broad blackish streak from $1 / 3$ of costa and an opposite dorsal streak forming a $\mathrm{V}$-shape at $1 / 2$ across wing, the dorsal streak followed by pale greyish scales with golden lusters in some lights; 3 very oblique slender blackish costal lines between $1 / 2$ and $2 / 3$, usually short, middle one approximated to basal one and often indistinct, these lines sometimes elongated and converging above tornal patch; a rather small elliptical tornal patch pale grey with silvery-metallic reflections; cilia white, but costal and apical cilia tinged with pale brown, along costa an oblique fuscous streak from $3 / 4$ to apex. Hindwings [and cilia white. Undersides of fore- and hindwings white.

Autumnal form: 今, $6.0 \mathrm{~mm}$. Thorax fuscous, except patagia and tegulae; forewings suffused with pale yellowish scales on apical half, fuscous scales scattered near base of dorsum, costal and dorsal streaks preceded by pale fuscous scales, and dorsal streak followed by a dark fuscous suffusion extending to tornal patch.

Male genitalia : Processes on 8th sternite triangular; genital ring elliptical; gnathos large, inversely triangular, dorsal margin concave at middle; valvae strongly sclerotized, divided into cuculus and sacculus by a incision; aedoeagus strongly sclerotized, rather short, united with valvae, apex with 2 lobes, base broadened, excavated on anterior edge.

Female genitalia : Papillae anales bluntly pointed ; apophyses anteriores slender, 
apophyses posteriores long and stout; some spines on posterior edge of 8th sternite; genital plate with an ovate plate on each side of ostium bursae; lamellae vaginales, an inversely V-shaped rime ; corpus bursae without Signum.

Holotype: $\hat{o}$, Mt. Hikosan, Fukuoka Pref., Kyushu, 1 Aug. 1956 (H. Kuroko).

Allotype: $q$, the same as holotype, 28 July 1963 (H. Kuroko).

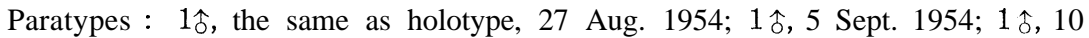
Oct. 1954; 2 沾, 17 Aug. 1958 (H. Kuroko). 1令, Okinawa, 16 Sept. 1957 (S. S. Nicolay), in Coll. Smithsonian Inst., U. S. Nat. Mus. Autumnal form-1 $\hat{\delta}$, the same as holotype, 15 Oct. 1954 (H. Kuroko).

Distribution : Japan (Kyushu), Okinawa.

This new species is simillar to M. metallifera Walsingham, of S. Africa but differs from it by the smaller size and the absence of the dark spots on the tornal patch.

\section{Biological notes}

Host plants : Leguminoseae-Glycine Max Merrill. (Jap. name : Daizu), Pueraria lobata (Willd.) Ohwi (Jap. name : Kuzu).

Mine \& frass : A linear-blotch mine; first linear mine commences from near the apex of the leaf and extends to the other leaf margin across the midrib in an arched line, and it runs again across the leaf by the other way; yellow to brown; 45-55 mm. in length. In consequence of crossing by the linear mine, the vitality of the apical part from the mine is weakened and the part changes to yellowish-green, sometimes becomes brown. The linear mine is abruptly broadened near the leaf margin and usually extends on apical part from the linear mine in an irregular blotch mine. Blotch mine pale yellowish-green ; partly making full depth or upper surface mine. The larva moves from one leaf to another one. One mine is found on a single leaf. Frasses greenish. black, scattered within the mine, somewhat in a winding line.

Cocoon: A spindle-shaped white cocoon $(6 \mathrm{~mm}$. in length, $2 \mathrm{~mm}$. in width) is covered by a H-shaped silken roof $(9 \mathrm{~mm}$. in length, $2.5 \mathrm{~mm}$. in width).

Development : There are 3 broods in a year on Mt. Hikosan. The larvae occur from the beginning to the middle of July, from the beginning to the middle of August and at the middle of September. The adults 'appear at the end of July, from the end of August to the beginning of September and from the beginning to the end of October.

\section{Genus Proleucoptera Busck}

(P1. 2, fig. 20)

Proleucoptera Busck, 1902, Jn. N. Y. Ent. Soc., 10 : 98; Forbes, 1923, Cornell Univ. Agr. Exp. Sta. Mem. 68: 151.

Type species : Leucopterasmilaciella Busck, 1901. 
Head tufted above; face smooth. Labial palpi short, drooping, or rudimentary. Maxillary palpi rudimentary. Tongue short, naked. Antennae under 1 of forewing, $\hat{o}$ simple; scape forming an eyecap. Posterior tibiae with long hairs above and below. Abdomen rather broad, spined dorsally.

Forewings broad-lanceolate, costa slightly arched, tornus rounded, apex long caudate; vein lb long furcate ; transverse vein present; 3 absent; 4 present; 6 to termen; 7 to costa; 6 and 7 separate or connate; 8 absent; 9 and 10 separate or stalked; 11 from central area of cell or near base ; ground color shining white, with 2 yellowish costal streaks margined with black, a yellowish suffusion on apical area, a raised metallic-colored patch on tornus, and some blackish lines in cilia. Hindwings 1/2, narrow-lanceolate ; cilia 3-4; transverse vein absent between 2 and $5 ; 2$ and 5 separated or connected near dorsum ; 6 present; shining white or greyish-brown.

Male genitalia: Eighth sternite rudiment, represented by 2 valva-like processes ; uncus absent; gnathos present on each side; valvae usually small and weak; aedoeagus with a broad or huge bulbous base.

Female genitalia : Papillae anales bluntly rounded or pointed; apophyses anteriores and apophyses posteriores short; lamellae vaginales pointed or undeveloped ; corpus bursae without signum.

\section{Key to the species of Proleucoptera based on marking}

1. Forewing with 2 blackish oblique strigulae and an erect strigula in costal cilia ................ . . smilactis sp. nov.

Forewing with 2 erect strigulae in costal cilia . . . . . . . . .

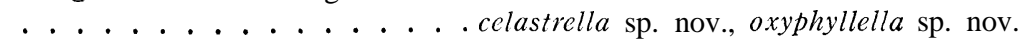

\section{Key to the species of Proleucoptera based on male genitalia}

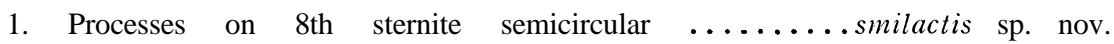
Processes on 8 th sternite tapered ............. 2

11. Processes on 8th sternite with a neb-shaped projection at apex ; valva rounded $\quad \ldots \ldots \ldots \ldots$...................... novtrella Processes on 8 th sternite with a hooked spine at apex; valva slender ..

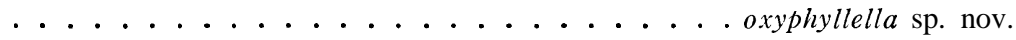

Proleucoptera smilactis sp. nov.

(P1. 1, fig. 12; Pl. 4, fig. 29; Pl. 10, fig. 50 ; Pl. 13, fig. 69; Pl. 17, fig. 84)

oㅇ․ 6-8 mm. Head and thorax shining white, vertex with a rather long white tuft. Labial palpi short, whitish, pale fuscous externally. Antennae $4 / 5$ of forewing; whitish-brown ; eyecap shining white. Anterior tibiae and tarsi dark fuscous. Posterior legs shining white ; tarsi annulated with black. Abdomen pale grey above, white below.

Forewings shining white; a very oblique slender pale yellowish streak from middle of costa reaching near $1 / 2$ across wing, finelly margined with dark fus- 
cous on both sides, a short slightly less oblique pale yellowish streak from $3 / 4$ reaching near apex of above-mentioned streak, margined with pale dark fuscous internally ; a leaden-metallic tornal patch margined with black scales internally and surrounded by some pale yellowish scales; cilia white except terminal cilia, 2 dark fuscous oblique strigulae and an erect strigula through costal cilia converging to a point beyond apex, the last strigula followed by some fuscous scales; terminal cilia pale brown. The venation and marking of forewing quite agree with those of smilaciella. Hindwings with venation as that of smilaciella: greyish-brown ; cilia pale fuscous. Undersides of fore- and hindwings

\section{f uscous.}

Male genitalia : Eighth tergite with a process which is incised at middle of posterior margin ; process on 8th sternite large and broadened; tuba analis conspicuously projected backward, truncated ; gnathos separated on each side, rounded, and hairy on ventral side; valvae narrow and rather long, apical 1/3 swollen and clothed with hairs; anellus weakly sclerotized ; aedoeagus long, narrow distally, broadened in basal $2 / 3$, a sclerotized dorsal spine at apical $1 / 5$, vesica pointed, curled

Female genitalia : Papillae anales bluntly rounded; apophyses posterior-es short, slender; apophyses anteriores a little longer; genital plate with some hairs on posterolateral edge of ostium bursae; ostium bursae circular; no Signum.

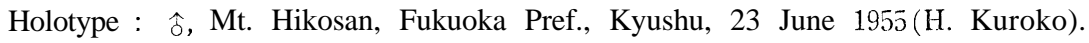
Allotype : , the same as holotype, 23 June 1955 (H. Kuroko).

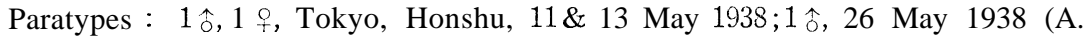
Kawada), in Coll. Nat. Inst. Agr. Sci. 1\%, the same as holotype, 5 Aug. 1954;

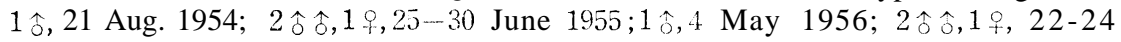

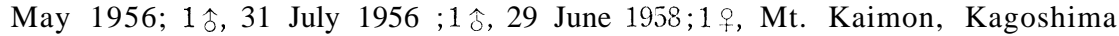
Pref., Kyushu, 19 May 1956; 1ㅇ, 22 May 1956 (H. Kuroko).

Distribution : Japan (Honshu, Kyushu).

This new species is similar to Lencopterahexatoma Meyrick, 1915, of India but differs from it by the absence of the apical hook of forewings and the dark color of hindwings. Also, this species is very closely related to Proleucoptera smilaciella Busck, 1901, the larva of which is known as a leaf miner of Smilax sp. from N. America, but in smilaciclla the hindwing is much darker and gnathos is longer in the male genitalia. Dr. J. F. Gate Clarke was kind enough to send me the Busck's specimens for comparison.

\section{Biological notes}

Host plant : Liliaceat-Smilax China Linn. (Jap. name : Sarutori-ibara).

Egg: Elliptical and flattened; $0.30 \mathrm{~mm}$. in length, $0.23 \mathrm{~mm}$. in width. The eggs is laid on the under side of the leaf of the host plant, not along the vein. One to several eggs are deposited on a single leaf.

Mine \& frass : An orthogenous blotch mine, upper surface type : pale 
greenish-brown, central patch brown $; 25-45 \mathrm{~mm}$. in diameter. One to several larvae are occupying in a single mine. Pale brown to blackish grains of frasses gathered or scattered near central area.

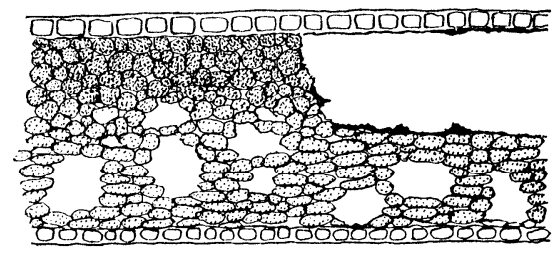

Fig. 4. Cross-section of the leaf of Smilax China Linn. with a mine of Proleucoptera smilactis sp. nov.

Cocoon: The shining white cocoons are found on the surface of the leaf or twig or others. The spindle-shaped cocoon $(7 \mathrm{~mm}$ in length, $2 \mathrm{~mm}$. in width) is covered by a $\mathrm{H}$-shaped silken roof $(10 \mathrm{~mm}$. in length, $4.3 \mathrm{~mm}$. in mid width), but the cocoon spun on the twig has no silken roof.

Development : Three broods in a year on Mt. Hikosan. The larvae feed from the end of May to the beginning of June, from the beginning to the end of July and at the beginning of October. The adults of first 2 broods appear at the end of June and from the beginning to the end of August respectively. The larvae of autumnal brood spin the white cocoon at the beginning of November and hibernate as a last instar stage, and the adults appear in $\mathrm{May}$ of the following year.

\section{Proleucoptera celastrella sp. nov.}

(P1. 4, fig. 11 ; P1.4, fig. 30; P1. IO, fig, 48; P1. 13, fig. 70 ;P1. 16, fig. 82)

o rudimentary. Antennae 5/6 of forewing; whitish-brown, becoming white towards apex ; eyecap shining white. Anterior tibiae and tarsi fuscous. Posterior legs shining white; tarsi annulated with blackish. Abdomen whitish-brown above, shining white below.

Forewings shining white; a pale yellowish suffusion occupying apical $1 / 4$ of wing, apex white; a very oblique slender pale yellowish streak from middle of costa to apical suffusion at disc, margined with a fine black line on each side: a short slightly less oblique pale yellowish streak from costa at $2 / 3$, finely margined with pale blackish internally ; a moderate leaden-metallic tornal patch margined with a blackish dot internally; cilia white except terminal cilia, on costa a short oblique blackish streak followed by pale yellowish scales, 2 erect strigulae in costal cilia, an oblique apical line from above apex and an apical hook from apex; terminal cilia tinged with yellowish-brown. Hindwings and cilia white. Underside of forewings suffused with faint fuscous.

Male genitalia : Posterior edge of 7 th sternite sclerotized and protruded in 
2 short triangles; processes on 8 th sternite with a neb-shaped projection at apex; gnathos forming a narrow pad on each side, clothed with fine hairs; valvae short and rounded, with several bristles externally; aedoeagus with a huge bulbous base.

Female genitalia : Papillae anales pointed ; apophyses anteriores and apophyses posteriores very short; lamellae vaginales sclerotized and pointed ; ductus bursae slender; corpus bursae rounded and scattered with minute spines, without signum.

Holotype : $\hat{o}$, Mt. Hikosan, Fukuoka Pref., Kyushu, 11 May 1954 (H. Kuroko).

Allotype: $q$, the same as holotype, 19 May 1954 (H. Kuroko).

Paratypes : 2令令, 2 우우, Tokyo, Honshu, 4-7 May 1938 (A. Kawada), in Coll. Nat. Inst. Agr. Sci. 3 令占, 6 우, the same as holotype, 11-22 May 1954; 4 우, 27 July-1 Aug. 1954 ;1\}, 11 May 1955 (H. Kuroko); 2 우우, Sapporo, Hokkaido, S Aug. 1956 (T. Kumata); 1 ㅇ, Sapporo, Hokkaido, 23 July 1958 ; 2 q + , the same as holotype, 9 Aug. 1960 (H. Kuroko).

Distribution : Japan (Hokkaido, Honshu, Kyushu).

This new species is allied to Leucopteracrobylistis Meyrick, 1926, and $L$. hexatoma Meyrick, 1915, of India. But crobylistis has not an apical line and apical hook on the forewing, and hexatoma has only a yellowish costal streak.

\section{Biological notes}

Host plants : Celastraceae-Tripterygium Regelii Sprangue et Takada (Jap. name: Kurozuru), Celastrus orbiculatus Thunb. (Jap. name : Tsuru-umemodoki), Euonymusalatus (Thunb.) Sieb. forma subtriflorus (Blume, pro sp.) Ohwi (Jap. name : Ko-mayumi).

Egg: Elliptical, about $0.30 \mathrm{~mm}$. in length and $0.23 \mathrm{~mm}$. in width. The eggs are laid on the upper side of the leaf of the host plant, usually along the mid rib, longitudinal axis of the egg being at a right angle to the rib. One to several eggs are found on a single leaf.

Mine: A blotch mine, sometimes digitate-blotch, upper surface type; pale green or pale brownish-green, central area turns dark brown by smearing viscid frasses inside of upper epidermis; feeding area being 151-207 $\mathrm{mm}^{2}$. One to several larvae are occupying a single mine.

Frass : Pale brown to blackish grains of frasses gathered at the central area besides frasses which are smeared inside of the epidermis.

Cocoon: The cocoon consists of a spindle-shaped true cocoon $(8 \mathrm{~mm}$. in length and $2.3 \mathrm{~mm}$. in width) and a H-shaped silken roof $(10 \mathrm{~mm}$. in length and $4 \mathrm{~mm}$. in mid width).

Development : Two generations in a year. The larvae of the 1 st generation occur from the beginning to the end of July and the adults appear from the end of July to the beginning of August. The larvae of the 2nd generation may be found at the middle of September; the larvae hibernate as a last instar stage in the mine. In the following spring, the hibernated larvae leave the mine and 
spin a white cocoon on the surface of the dead leaf or others, and pupate at the middle of April. The adults appear from the middle of May to the begin ning of June.

\section{Proleucoptera oxyphyllella sp. nov.}

(P1. 10, fig. 49; P1. 17, fig. 83)

$\hat{0} .8 \mathrm{~mm}$. This new species is so closely related to celastrella, that it is impossible to distinguish it from the latter by superficial characters.

Male genitalia : processes on 8th sternite tapered towards apex, with a hooked spine at apex ; gnathos forming a hairy short projection on each side ; valvae slender, weakly sclerotized, gently geniculate; costal projection, a hairy lobe; aedoeagus with a huge bulbous base, apical portion narrower and longer than that of celastrella.

I have not seen the female specimen.

Holotype: 今, Mt. Hikosan, Fukuoka Pref., Kyushu, 6 May 1955 (H. Kuroko).

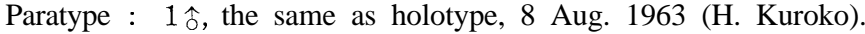

Distribution : Japan (Kyushu).

The male genitalia of this species is different from that of celastrella in the following points : apex of process on 8th sternite narrower, with a hooked spine instead of neb-shaped projection ; valvae more slender, and having a hairy costal projection.

\section{Biological notes}

Host plants : Celdastraceae-Euonymus oxyphyllus Miq. (Jap. name : Tsuribana).

Mine \& frass: A digitate-blotch mine, upper surface type; pale green, by viscid frasses the central area turns dark brown circularly and surroundings of this central patch tinged with pale red; feeding area being about $181 \mathrm{~mm}$ ? Blackish grains of frasses arranged radially from the central patch.

Development : Two generations in a year. The larvae of the 1 st generation occur at the end of July and the adults appear at the beginning of August. The larvae of the 2nd generation which occur in October, hibernate as a last instar stage in the mine and crawl out from the mine in the following spring and spin a white cocoon like the case of celastrella. The adults appear at the beginning of May.

\section{Genus Paraleucoptera Heinrich}

(P1. 2, fig. 21)

Paralcucoptera Heinrich, 1918, Proc. Ent. Soc. Washington, 20 (1): 21-22.

Type species : Cemiostomaalbella Chambers, 1871.

Head short tufted above; face smooth. Labial and maxillary palpi rudimentary-. Tongue short, naked. Antennae $4 / 5$ of forewing, 令 simple; scape forming an eyecap. Posterior tibiae clothed with long hairs above and below. Abdomen rather broad, spined dorsally. 
Forewings broad-lanceolate, costa slightly arched, tornus gently curved, apex short protruded, pointed ; vein lb furcate; transverse vein weak; 3 absent; 6 and 7 stalked or separate; 9 and 10 stalked; 11 absent; ground color shining white, with 2 yellowish costal streaks and a yellowish apical patch margined with black, and a raised metallic-colored patch on tornus. Hindwings 1/2, narrow-lanceolate, cilia 3-4'; transverse vein absent between 2 and 5, 6 absent; shining white.

Male genitalia : Eighth sternite with 2 broad processes; valvae clothed with 2 kinds of hairs; saccus undeveloped ; aedoeagus broadened basally.

Female genitalia: Apophyses anteriores and apophyses posteriores short; lamellae vaginales triangularly pointed ; corpus bursae without Signum.

\section{Paraleucoptera sinuella (Reutti)}

(P1. 4, fig. 31; P1. 10, fig. 51)

Cemiostoma sinuella Reutti, 1853, Beit. Rheinischen Naturgeschichte, 3 : 208.

Cemiostoma susinella Herrich-Shaeff er, 1855, Schmett. Eur., 5 :342; Stainton, $185 j$, Nat. Hist. Tin., 1: 288; Snellen, 1882, Vlind. Ned., 2 : 949; Rebel, 1310, in Staudinger-Rebel, Cat. Lep. Pal., 2: 218; Spuler, 1910, Schmett. Europ., 2: 23 . Paraleucoptera susinella: Heinrich, 1918, Proc. Ent. Soc. Washington, 20 (1):22. Leucoptera susinella: Meyrick, 1929, Rev. Hand. Brit. Lep. : 808; Issiki, 1950, in Icon. Ins. Jap., (ed. 2): 445, f. 1198 ; Inoue, 1954, Check List. Lep. Jap., Part 1: 25; Issiki, 1957, in Icon. Het. Jap. Col. Nat., 1: 18, pl. 2, f. 57; Okano,1952, in Icon. Ins. Jap. Col. Nat., 1: 276, pl. 182, f. 27.

Leucoptera sinuella: Hering, 1933, Mitt. Zool. Mus. Berlin, 19: 68; Pierce \& Metcalfe, 1935, Genitalia Tin. Fam. Lep. Brit. Is.: 89, pl. 55.

Paraleucoptera sinuella: Hering, 1957, Bestimm. Blatt. Europ., 2: 812 \& 926.

今우. $6 \mathrm{~mm}$. Head, tuft, face, and thorax shining white. Antennae greyishfuscous, apical 3 joints white; eyecap shining white. Anterior tibiae and tarsi pale brown. Posterior legs shining white; tarsi dotted with pale fuscous, $A b$ domen greyish-fuscous above and posterior margin of each segment white, shining white below.

Forewings shining white; a pale yellowish apical patch occupying $2 / 5$ of wing, margined with pale fuscous internally; an oblique rather broad pale yellowish streak beyond middle of costa to apical patch, margined with dark fuscous on both sides, a short erect pale yellowish streak from costa at $3 / 4$, margined with dark fuscous internally; apex with some white scales; a rather leaden-metallic tornal patch margined with black scales internally and externally ; cilia white except apical cilia ; an inwardly oblique fuscous strigula in costal cilia; apical cilia tinged with pale fuscous. Hindwings and cilia shining white. Underside of forewings pale fuscous on dorsal half.

Male genitalia : Processes on 8th sternite broad and petaloid; tuba analis projecting posteriorly; valvae elliptical in apical half, clothed internally with 2 kinds of hairs: one fan-shaped and another barbed; aedoeagus tapered towards apex, 2 pointed, apical $1 / 3$ swollen ventrally and basal half broadened.

Female genitalia : Papillae anales pointed; apophyses anteriores and apophyses 
posteriores very short ; lamella antevaginalis, a small narrow triangular plate, clothed with minute hairs distally; no signum.

Specimens examined : 2ㅅํㅇ, 2 우우, Tokyo, Houshu, 2-3 May 1938 (A. Kawada), in Coll. Nat. Inst. Agr. Sci. 1令, Sapporo, Hokkaido, 27 July 1956; $1 \hat{\jmath}, 8$ Aug. 2956 (T. Kumata).

Distribution : Japan (Hokkaido, Honshu), Europe, N. Africa.

These Japanese specimens only differs from the nominate race of Europe in having a rather broad pale yellowish patch before the metallic tornal patch.

Host plants : SAlicACEAE-Populus Sieboldi Miq. (Jap. name : Yamanarashi), $P$. alba Linn. (Jap. name : Urajiro-hakoyanagi), P.nigra Linn. var. italica Muenchh. (Jap. name : Seiyo-hakoyanagi), in Japan.

\section{Genus Leuesptera Huebner}

(Pl. 2, fig. 22)

Leicoptera Huebner, [1825], Verz.bekannt. Schmett., (27): 426; Meyrick, 1929, Rev. Hand. Brit. Lep: 808; Forbes, 1923, Cornell Univ. Agr. Exp. Sta. Mem. 68: 151; Hering, 1933, Mitt. 2001. Mus. Berlin, 19 : 64; Pierce \& Metcalfe, 1935, Genitalia Tin. Fam. Lep. Brit. Is.: 88.

Cémiostoma Zeller, 1848, Linnaea Entom., 3 : 272 ; Stainton, 1854, Ins. Brit., Lep. : 286 ; id., 1855, Nat. Hist. Tin., 1: 234-292; Snellen, 1882, Vlind. Ned., 2 : 947 ; Spuler, 1910, Schmett. Europ., 2: 423.

Type species : Tineaspartifoliella Huebner, 1816.

Head usually smooth (tufted in scitella); face smooth. Labial and maxillary palpi rudimentary. Tongue short, naked. Antennae $4 / 5$ of forewing, 令 simple; scape forming an eyecap. Posterior tibiae with long hairs above and below. Abdomen rather broad, spined dorsally.

Forewings broad-lanceolate, costa slightly arched, tornus gently curved, apex protruded, long caudate; vein lb simple; transverse vein absent between 2 and 5 <present in scitella); 3 and 4 absent ; 5 and 6 stalked, 6 to termen or apex; 7 and 3 absent; 9 and 10 sometimes stalked; 11 usually absent (present in lustratella); ground color shining white (rarely leaden-grey), commonly 2 yellowish costal streaks margined with black, a yellowish apical patch and a raised metallic-colored tornal patch. Hindwings $1 / 2$, narrow-lanceolate, cilia 3 ; transverse vein absent between 2 and 5; shining white or pale grey.

Male genitalia : Eighth sternite rudiment, represented by 2 processes*; uncus usually absent ; gnathos usually present on each side ; valvae various; saccus usually undeveloped; aedoeagus usually with a broad or huge bulbous base.

_. Female genitalia; Papillae anales bluntly pointed to rounded; lamellae vagin-

* Pierce \& Metcalfe (1935) regarded these processes as valvae, but it seems that their mistreatment was caused by the miscounting of the abdominal segments. 
ales pointed; ductus bursae usually slender; corpus bursae without Signum.

Leucoptera puerariella sp. nov.

$$
\text { (P1. 4, fig. 32; P1. 11, fig. 52; P1. 17, fig. 85) }
$$

今. 4-5 mm. Head smooth, shining white. Antennae greyish-brown ; eyecap shining white. Thorax shining white. Anterior tibiae and tarsi dark fuscous. Posterior legs shining white; tarsi greyish-black except apical 2 joints. Abdomen greyish-fuscous above, shining white below.

Forewings shining white ; costal edge blackish from base to costal streak; a shining yellow-orange apical patch occupying $1 / 3$ of wing, sometimes dorsal half dark; a large blue-leaden-matellic tornal patch followed by a black dot ; a very oblique black costal streak from beyond middle to yellow-orange apical patch; cilia white, apical and terminal cilia pale fuscous distally ; 2 black costal strigulae above apical patch; an erect costal strigula from shortly before apex ; an apical pencil and an apical hook from apex. Hindwings shining white, tinged with pale fuscous apically; cilia shining white except pale fuscous of apical cilia. Underside of forewings fuscous and of hindwings fuscous on costal half.

Male genitalia : Processes on 8th sternite oblong; tuba analis weakly sclerotized, protruded, with some hairs ventrally; gnathos divided on each side, short and slender, weakly sclerotized, with 2 hairs at apex; rather sclerotized valvae short, apex rounded, with some bent hairs distally; saccus exceptionally elongated; aedoeagus long and slender, apex curved, base broadened.

I have not seen the female specimen.

Holotype :令, Mt. Hikosan, Fukuoka Pref., Kyushu, 29 July 1955 (H. Kuroko).

Paratypes : 4令令, Tokyo, Honshu, 12-13 May 1939 (A. Kawada), in Coll. Nat. Inst. Agr. Sci.

Distribution : Japan (Honshu, Kyushu).

This new species is related to Leucoptera erebastra Meyrick, 1934, of India but differs from it in having the yellowish apical patch on the forewing and scattering of frasses of the larva in the mine instead of gathering.

\section{Biological notes}

Host plant : Leguminosae-Pueraria lobata (Willd.) Ohwi (Jap. name : Kuzu).

Mine \& frass : An irregular blotch, upper surface mine; expanding along the leaf margin or vein; pale greenish-brown ; feeding area being about $56 \mathrm{~mm}^{2}$. One to 3 mines are found on a single leaf. Fuscous frasses are scattered somewhat in a linear arrangement.

Cocoon: When full fed, the larva leaves the mine and clawls to the leaf margin, and there makes a spindle-shaped white cocoon $(5.0 \mathrm{~mm}$. in length, 0.8 $\mathrm{mm}$. in width) covered by a flattened thin silken web.

Development : It seems that the species repeats 2 or 3 generations in a year. The larvae may be found feeding from the beginning to the middle of July and from the beginning to the middle of October on Mt. Hikosan. The adults 
of the summer brood appeared at the end of July, but the autumnal larvae failed to make hibernation. When succeeded to hibernate, the adults seem to appear in the following May.

\section{Exclusion of unrelated forms}

The following species have hitherto been treated erroneously as belonging to the family Lyonetiidae, so I dealt them as follows in this paper.

1. Lyoneta (sic) jezonella Matsumura† (6000 Ill. Ins. Jap.: 1105, no. 2306, 1931) is the synonym of Caloptiliaalbicapitata Issiki, 1930 (Lithocolletidae).

2. Lyoneta (sic) multimaculata Matsumura† (6000 Ill. Ins. Jap. : 1106, no. 2309,

1931) should be transfered to the genus Callisto (Lithocolletidae).

3. Dryadula (sic) ainoniella Matsumurał (6000 Ill, Ins. Jap.: 1105, no. 2305, 1931) is the synonym of Leucospilapteryxomissella (Stainton, 1848) (Lithocolletidae).

\section{List of the host plants of Lyonetia in the world}

(*Newly reported host plants in this paper)

\begin{tabular}{|c|c|c|}
\hline Species \& subspecies & Host plants & Localities \\
\hline aliclla Chambers, 1875 & Alnus sp. (Betulaceae) & N. America \\
\hline anthemopa Meyrick, 1936 & $\begin{array}{l}\text { Pyracantha angustifolia, } \\
\text { P. crenūrata, Raphiolepis } \\
\text { umbellata, Photinia taiwan- } \\
\text { ensis ( RosacEAE) }\end{array}$ & $\begin{array}{l}\text { Japan, } \\
\text { Formosa }\end{array}$ \\
\hline bakuch in sp. nov. & Prunus Zippeliana* (R OSACEAE) & Japan \\
\hline boehmeriella sp. nov. & $\begin{array}{l}\text { Boehvneria spicata*, } B . \\
\text { nipononivea* } \text { (URTICACEAE) }^{*}\end{array}$ & Japan \\
\hline castaneella sp. nov. & $\begin{array}{c}\text { Castanea crenata*,Quercus } \\
\text { acutissima* }\left(\mathrm{F}_{\mathrm{AGACEAE}}\right)\end{array}$ & Japan \\
\hline $\begin{array}{l}\text { clerkclla (Linnaeus, 1758) } \\
\text { (=unipunctella Stephens, } \\
\text { cerasifoliella Huebner, }\end{array}$ & $\begin{array}{l}\text { Malus hortensis, M.pumila, } \\
\text { Prunus Persica, P. Jama. } \\
\text { sakura, P.Avium, P.padus, }\end{array}$ & $\begin{array}{l}\text { Japan, } \\
\text { Formosa, } \\
\text { India, }\end{array}$ \\
\hline
\end{tabular}

$\dagger$ Dr. T. Kumata of Hokkaido University kindly examinated the Matsumura's type specimens deposited in the Institute of the University for me and gave me such information.

$\div$ This fact has been reported by Dr. Kumata (1963). 
Species \& subspecies

Host plants

Localities

malifoliella Huebner, clerkella Treitschke, aereella Treitschke) euryella sp. nov.

frigidariella Herrich-

Schaeff er, 1855

latistrigella Walsingham, 1882

ledi Wocke, 1859

(=candida Braun) myricel la sp. nov.

prunifoliella (Huebner, 1816)

(=padifoliella Huebner, albella Eversmann, schineri Nowicki)
$P$. domestica, $\mathbf{P}$. Cerasus, Cerasus mahaleb, $C$. lauroce. rasus, Pyrus sp. Amelan- chier sp., Crataegus sp., Mespilus sp., Cydonia sp., Chaenomeles sp., Cotoneaster sp., Sorbus suecica, S. aucuparia (ROSACEAe); Humulus sp. (Moraceae); Betula sp. (Betulaceae); Salix sp. (Salicaceae); Castanea sp. (FAGACEAE); Eucalyptus sp. (MYRTACEAE)

Eruope,

Eurya japonica, E. emarginat $a^{*}$ (THEACEAE)

Salix angustf. (SALLCACEAE)

Japan

Europe

Rhododendron maximum
(ERICACEAE)

Rhododendron mucronulatum*,

R. kaempferi*, R. dauricum*,

R. occidental, R. albiflorum,

Meziesia pentandra*, Ledum palustre (ERICACEAE); Myrical gale ( MyricaceaE)

Myrica rubra* (MYRICACEAE) Japan,

Prunus spinosa, P. padus, Pyrus sp., Malus sp.,

Europe, Asia Minor
N. America

Japan, Europe, N. America

\section{Cotoneaster sp., Cra taegus}

sp., Chaenomeles sp., Mespilus sp., Cydonia sp., Sorbus sp. (RosACEAE);

Betula pubescens

(Betulaceae)

Malus pumila, M. Sieboldii (Rosacear)

Kalk sp. (AnONACeaE)

subsp. malinella (Matsumura, 1907) ( = malivorella Matsumura, ringoniella Matsumura) pyrrhoplaca Meyrick, 1936 
Species \& subspecies

Host plants

Localities

saliciella Busck, 1904

speculella Clemens, 1861

(=nidificansella Packard, gracilella Chambers, apicistrigella Chambers)

yasudai sp. nov.

Salix sp. (Salicaceae) N. America

Ceanothus americanus

$N$. America

(Rham naceae); Malusmalus, Prunus sp. (Rosaceae);

Betula sp. ( Betula te a e); Vitis sp. $^{1)}$ (VItAceae)

Quercus acuta* (FAGACEAE)

Japan

1) It is questionable whether the determination of the miner of the plant is right or not.

List of the host plants of Leucopterinae in the world ${ }^{2)}$

(*Newly reported host plants in this paper)

Species \& subspecies

aceris (Fuchs, 1903)

(Leucoptera)

adenocarpella (Staudinger,

1870) (Leucoptera)

albella (Chambers, 1871)

(Paraleucoptera)

brachyscia Meyrick, 1934

(Leucoptera)

caffeina Washbourn, 1940

(Leucoptera)

calycotomella Amsel, 1939

(Leucoptera)

celastrella sp. nov.

(Proleucoptera)
Host plants

Localities

Acer monspessulanum

(ACERACEAE)

Adenocarpus sp.

(Leguminosae)

Populus alba, P. Dilatata, N. America Salix sp. (Salicaceae)

Ougeina dalbergioides India

(Leguminosae)

Coffea $a$ Spp. (RIJ BIACEAE) $\quad$ E. Africa

Calycotome sp. (Leguminosae) S. Europe

Tripterygium Regelii*, Celastrus orbiculatus*, Euonymus alatus*

(Celastraceae)
Europe

S. Europe

Japan

2) The taxonomic studies of Leucopterinae in the world remain imperfect and many amendments of generic names of the species included in it should be done in the future. Therefore, the present generic position of each species is only cited in parentheses. 


\begin{tabular}{c} 
Species \& subspecies \\
\hline clerodendrella Vari, 1955 \\
(Leucoptera) \\
coffeella (Guerin-Meneville, \\
1842) (Leucoptera) \\
coronillae (Hering, 1933) \\
(=phyllocytisi Hering) \\
(Leucoptera)
\end{tabular}

crobylistis Meyrick, 1926

(Leucoptera)

cytisiphagella Klimesch, 1938

(Leucoptera)

daricella (Meyrick, 1881)

( = sta terias Meyrick, onychotis Meyrick)

(Leucoptera)

erebastra Meyrick, 1934

(Leucoptera)

erythrinella Busck, 1901

(Leucoptera)

genistae (Hering, 1933)

(Leucoptera)

glycinella sp. nov.

(Microthauma)

guettardella Busck, 1900

(Leucoptera)

heringiella Toll, 1938

(Leucoptera)

laburnella (Stainton, 1851)

(Leucoptera)

subsp. cytisella Amsel, 1939

lathyrifoliella (Stainton, 1866)

(Leucoptera)

lotella (Stainton, 1858)

(Leucoptera)
Host plants

Clerodendrum glabrum

( Verbenaceae )

Coffea arabica (RubiaceaE)

Cytisus sessilifolius

( Legu minosae)

Pavetta indica(Rubiaceae) India

Cytisus austriacus

(Leguminosae)

Plumbago zeylanica, $P$. capensis (Plumbaginaceae)

Flemingia strobilifera

(Leguyinosae)

Erythrina herbacea

( Leguminosae )

Genista anglica

(Leguminosae)

Pureraria loba ta*, Glycine Max* ( Leguminosae)

Guettarda elliptica

(RUBiaceae)

Cytisus nigricans, C. hirsutus Europe (Leguminosae)

Cytisus laburnum, C. alpinus, Europe Laburnum vulgare, $L$. anagyroides, Petteria sp. (Leguminosae)

Cy tisus sp. (Leguminosae)

La thyrus silvester

(Leguminosae)

Lotus corniculatus, $L$. uliginosus, L. hispidus, Tetragonolobus siliquosus (LEGUMinosae)
S. Europe

Localities

S. Africa

, West Indies, , S. America

Europe

Europe

Queensland, S. Africa, India, Ceylon, Burma

India

$N$. America

Europe

Japan

N. America

Europe

Europe 


\begin{tabular}{|c|c|c|}
\hline Species \& subspecies & Host plants & Localities \\
\hline $\begin{array}{l}\text { loxaula Meyrick, } 1928 \\
\text { (Leucoptera) }\end{array}$ & Pavetta assimilis (R UBIACEAE) & S. Africa \\
\hline $\begin{array}{l}\text { loxoclista Meyrick, } 1934 \\
\quad \text { (Leucoptera) }\end{array}$ & $\begin{array}{l}\text { Bridelia retusa } \\
\text { (EUPHORBIACEAE) }\end{array}$ & India \\
\hline $\begin{array}{l}\text { lustratella (Herrich-Schaeff er, } \\
\text { 1855) (Leucoptera) }\end{array}$ & $\begin{array}{l}\text { Hypericum montanum, } H \text {. } \\
\text { perforatum, } H . \text { quadran- } \\
\text { gulum (GUTTIFERE) }\end{array}$ & Europe \\
\hline $\begin{array}{l}\text { meyricki Ghesquière, } 1940 \\
\text { (Leucoptera) }\end{array}$ & Coffea spp. ( Rubiaceae) & E. Africa \\
\hline $\begin{array}{l}\text { onobrychidella Klimesch, } 1937 \\
\text { (Leucoptera) }\end{array}$ & $\begin{array}{l}\text { Onobrychis sativa, } 0 . \\
\text { viciaefolia (LEGUM INOSAE) }\end{array}$ & Europe \\
\hline $\begin{array}{l}\text { orobi }(\text { Stainton, 1870) } \\
\quad \text { (Leucoptera) }\end{array}$ & $\begin{array}{l}\text { Lathyrus macrorrhizus, L. } \\
\text { tuberosus, L. montanus } \\
\text { (LEGCJMINOSAE) }\end{array}$ & Europe \\
\hline $\begin{array}{l}\text { oxyphyllella sp. nov. } \\
\text { (Proleucoptera) }\end{array}$ & $\begin{array}{l}\text { Euonymus oxyphyllus* } \\
\text { (CELASTRACEAE) }\end{array}$ & Japan \\
\hline $\begin{array}{l}\text { pachystimella Busck, } 1904 \\
\quad \text { (Leucoptera) }\end{array}$ & $\begin{array}{l}\text { Pachystima myrsinites } \\
\text { (CELASTRACEAE) }\end{array}$ & N. America \\
\hline $\begin{array}{l}\text { picrocosma Meyrick, } 1915 \\
\quad \text { (Leucoptera) }\end{array}$ & $\begin{array}{l}\text { Mussaenda frondosa } \\
\text { ( RUBIACEAE) }\end{array}$ & India \\
\hline $\begin{array}{l}\text { puerariella sp. nov. } \\
\text { (Leucoptera) }\end{array}$ & $\begin{array}{r}\text { Pueraria lobata* } \\
\text { (LEGUNM IN OSAE) }\end{array}$ & Japan \\
\hline $\begin{array}{l}\text { pulchricola Vari, } 1955 \\
\text { (Leucoptera) }\end{array}$ & Ochna pulchra (0 CHNACEAE) & S. Africa \\
\hline $\begin{array}{l}\text { robinella Braun, } 1925 \\
\quad \text { (Leucoptera) }\end{array}$ & $\begin{array}{l}\text { Robinia neomexicana } \\
\text { (LEGUminosaE) }\end{array}$ & N. America \\
\hline $\begin{array}{l}\text { scitelia (Zeller, 1839) } \\
\quad \text { (Leucoptera) }\end{array}$ & $\begin{array}{l}\text { Prunus spinosa, Cydonia sp., } \\
\text { Cotoneaster sp., Mespilus sp., } \\
\text { Chrataegus Oxyacantha, } \\
\text { Chaenomeles sp., Sorbus } \\
\text { aucuparia, Amelanchier sp., } \\
\text { Malus pumila, M. prunifolia, } \\
\text { M. Sieboldii, M. manchurica, } \\
\text { M. silvestris, Pyrus } \\
\text { aucuparia, P. malus, P. } \\
\text { communis (R osACEAE); } \\
\text { Betula pubescens, Alnus sp. } \\
\text { (BETULACEA) }\end{array}$ & $\begin{array}{l}\text { Europe, } \\
\text { N. China }\end{array}$ \\
\hline $\begin{array}{l}\text { sinuella (Reutti, 1853) } \\
\text { (= susinella Herrich- } \\
\text { Schaeffer) (Paraleucoptera) }\end{array}$ & $\begin{array}{l}\text { Populus Sieboldi, P. alba, } P . \\
\quad \text { nigra, Salix sp. (SAliCACEAE) }\end{array}$ & $\begin{array}{l}\text { Japan, } \\
\text { Europe, } \\
\text { N. Africa }\end{array}$ \\
\hline
\end{tabular}




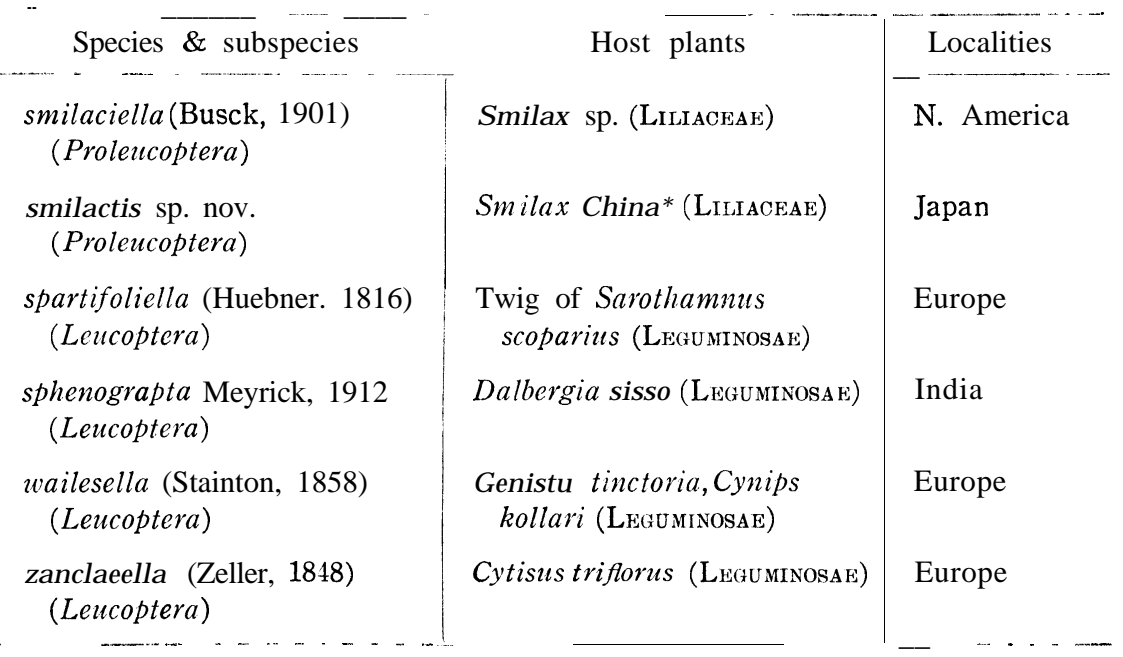

\section{Annotated list of the Japanese Erechthiidae, Oinophilidae, and Lyonetiidae}

\section{Family Erechthiidae}

Genus Decadarchis Meyrick, 1886, Trans. Ent. Soc. London., 1886: 290.

Type speies : Decadarchis melanastra Meyrick, 1886

D. atririvis Meyrick, 1931

D. sphenoschista Meyrick, 1931

D. ioloxa Meyrick, 1936

Genus Thermocrates Meyrick, 1936, Exot. Microlep., 4: 620.

Type species : Theemocmtes epischista Meyrick, 1936 T.episch ista Meyrick, 1936

\section{Family Oinophilidae}

Genus Opogona Zeller, 1853, Bull. Soc. imp. Nat. Moscou, 26 (2): 504-507. (= Loxostoma Stainton, 1859 ;Conchyliospila Wallengren, 1861; Cachura

Walker, 1864 ; Dendroneura Walsing ham, 1892 ; Hieroxestis Meyrick, 1892)

Type species : Opogona dimidiatella Zeller, 1853

0. thiadelpha Meyrick, 1934

0. nipponica Stringer, 1930

0. cerodelta Meyrick, 1911

(=Bucculatrix auripicta Matsumura, 1931, 6000 111. Ins. Jap.: 1105, no. 2304, syn. nov.)

Family Lyonetiidae

Subfamily Bedelliinae

Genus Bedellia Stainton, 1849

B. somnulentella (Zeller, 1847) 
(=orpheella Stainton, 1849 ; convolvulella Fologne, 1860 ; staintoniella

Clemens, 1860 ; mnesileztca Meyrick, 1928 ;ipomoeae Bradley, 1953)

Subfamily Bucculatricinae

Genus Buccula trix Zeller, 1839

(= Ceroclastis Zeller, 1848)

$B$. pyrivorella $s p$. nov.

B. exedra Meyrick, 1915

Subfamily Lyonetiinae

Genus Lyonetia Huebner, [1825]

Subgenus Lyonetiola nov.

L. (Lyonetiola) castaneella sp. nov.

L. (Lyonetiola) myricella sp. nov.

L. (Lyonetiola) euryella sp. nov.

Subgenus Lyonetia Huebner, [1825]

L. (Lyonetia) boehmeriella sp. nov.

L. (Lyonetia) ledi Wocke, 1859

(= candida Braun, 1916)

L. (Lyonetia) prunifoliella malinella (Matsumura, 1907)

(= malivorella Matsumura, 1906 ; ringoniella Matsumura, 1931)

L. (Lyonetia) anthemopa Meyrick, 1936

L. (Lyonetia) yasudai sp. nov.

L. (Lyonetia) bakuchia sp. nov.

L. (Lyonetia) clerkella (Linnaeus, 1758)

( = cerasifoliella Huebner, 1816 ; malifoliella Huebner, 1816 ; unipunctella

Stephens, 1829 ; clerkella Treitschke, 1833 ; aereella Treitschke, 1833 ; autumnella Stephens, 1835)

Subfamily Leucopterinae

Genus Microthauma Walsingham, 1891

M. glycinella sp. nov.

Genus Proleucoptera Busck, 1902

$P$. smilactis sp. nov.

$P$. celastrella sp. nov.

$P$. oxyphyllella sp. nov.

Genus Paraleucoptera Heinrich, 1918

P. sinuella (Reutti, 1853)

(=susinella Herrich-Schaeff er, 1855)

Genus Leucoptera Huebner, [1825]

(= Cemiostoma Zeller, 1848)

L. puerariella sp. nov. 


\section{References}

Bradley, J. D. (1953). New Microlepidoptera from Fiji. Proc. Hawaiian Ent. Soc., 15 (1): 109-114.

-.. (1956). Microlepidoptera from Lord Howe Island and Norfolk Island. Bull. Brit. Mus. (Nat. Hist ) Entomology, 4 (4) : 145-164.

(1957). Microlepidoptera from Rennell and Bellona Islands. Nat. Hist. Rennell Isl. Brit. Solomon Isls., 2: 87-112, 12 pls.

--- (1959). Taxonomic notes on Leucoptera meyricki Ghesquière and Leucoptera coffeella (Guérin-Méneville). Bull. ent. Res., 49 : 417-419.

(1961). Microlepidoptera from the Solomon Islands. Bull. Brit. Mus. (Nat. Hist.) Entomology, 10 (4): 9-168, 15 pls.

(1962). Microlepidoptera from the New Hebrides. Bull. Brit. Mus. (Nat. Hist.) Entomology, 12 (5): 249-271, 14 pls.

Braun, A. F. (1916). New species of Microlepidoptera. Canad. Ent., 48 : 138-141.

----- (1925). New Microlepidoptera from the Southwest. Canad. Ent., 57 : $147-150$.

(1958). Taxonomy of the North American species of Bucculatrix: Correlation of genital structure with food plant groups. Proc. 10th Int. Congr. Ent. Montreal, 1956, 1: 297.

(1963). The genus Bucculatrix in America North of Mexico (Microlepidoptera). Mem. Amer. Ent. Soc., No. 18: 1-208, 45 pls.

Brown, S. C. S. (1954). The British Lyonetiidae. Proc. S. Lond ent. nat. Hist. Soc., 1952-53: 110-116, 1 pl.

Brues, C. T., A. L. Melander \& F. M. Carpenter. (1954). Classification of Insects. Cambridge.

Busck, A. (1901). New species of moths of the superfamily Tineina from Florida. Proc. N. S. Nat. Mus., 23: 225-254.

(1901). in Dyar, notes on the winter Lepidoptera of Lake Worth, Florida. Proc. Ent. Soc. Washington, 1901: 446-485.

- (1903). Notes on Brackenridge Clemens' types of Tineina. Proc. Ent. Soc. Washington, $5: 181-220$.

(1903). in Dyar, larvae of moths from Colorado. Proc. U. S. Nat. Mus., 25: 408-412.

(1904). Tineid moths from British Columbia. Proc. U. S. Nat. Mus., $27: 767-775$.

(1914). On the classification of the Microlepidoptera. Proc. Ent. Soc. Washington, 16: 46-54, pl. 1.

(1931). On the female genitalia of the Microlepidoptera and their importance in the classification and determination of the moths. Bull. Brooklyn Ent. Soc., 26 (5): 199-211, 5 pls.

Busck, A. \& C. Heinrich. (1921). Male genitalia of the Microlepidoptera. Proc. Ent. Soc. Washington, 23 (6): 145-152.

Chambers, V. T. (1871). A new species of Cemiostoma. Canad. Ent., 3: 23-25.

Chapman, T. A. (1902). The classification of Gracilaria and allied genera. The Entomologist, 35 : 81-88, 138-142, 159-164. 
Clarke, J. F. G. (1955). Catalogue of the type specimens of Microlepidoptera in the British Museum (Natural History) described by Edward Meyrick, 1. London.

Diakonoff, A. (1955). Microlepidoptera of New Guinea. Verh. Akad. Wet. Amst. (Afd. Natuurk.) (2) 50, no. 3. Amsterdam.

Dyar, H. G. (1902). A list of North American Lepidoptera and key to the literature of this order of insect. Bull. U. S. Nat. Mus., No. 52, 723 pp.

Eyer, J. R. (1926). Characters of family and subfamily significance in the male genitalia of Microlepidoptera. Ann. Ent. Soc. Amer., 19: 237-244, 2 pls.

Fletcher, T. B. (1921). Life-histories of Indian insects, Microlepidoptera. Mem. Dept. Agr. India, Ent. Ser. 6, Nr. 1-9.

- (1933). Life-histories of Indian Microlepidoptera (2nd Ser.). Scient. Monogr. Imp. Counc. Agr. Res., 4.

Forbes, W. T. M. (1923). The Lepidoptera of New York and neighboring states. Primitive forms, Microlepidoptera, Pyraloids, Bombyces. Cornell Univ. Agr. Exp. Sta., Memoir 68: 1-729.

Frey, H. (1880). Die Lepidopteren der Schweiz. Leipzig.

Frost, S. W. (1924). Two little known leaf-miners of apple (Lepid.: Tineidae; Col. : Curculionidae). Ent. News, 35: 132-134.

Gerasimov, A. M. (1952). Fauna USSR. Insecta. Lepidoptera 1 (2); Larvae 1. 2001. Inst. Akad. Nauk. USSR. Moscow.

Gozmány, L. (1956). Fauna Hungariae 13, Microlepidoptera 2. Budapest.

Harukawa, C. \& N. Yagi (1918). The serpentine leaf-miner of the peach, a species of Lyonetia. Ber. Ohara-Inst., 1 (3): 335-348, 1 pl.

Healy, C. (1865). Observations on the economy, moulting, and pupation of the the larva of Lyonetia clerckella. Ent. Mo. Mag., 2: 128-129.

Heinrich, C. (1918). A new genus of Lepidoptera allied to Leucoptera Hübner. Proc. Ent. Soc. Washington, 20 (1): 21-22.

Hering, E. M. (1927). Lepidoptera. in Tierwelt Mitteleuropas, 6, 3 Teil. Leipzig. (1933). Die palaearktischen Arten der Gattung Leucoptera Hbn. (Cemiostoma Zeller) (Lep. Cemiost.). Mitt. Zool. Mus. Berlin, 19: 64-79.

(1933). Recherches de mines aux environs de Paris. Amat. Papill., $6: 187-195$.

(1951). Biology of the leaf miners. s'-Gravenhage.

---- (1957). Bestimmungstabellen der Blattminen von Europa. 1-3. s'Gravenhage.

Heyden, C. V. (1861). Fragmente aus meinen entomologischen Tagebüchern. Stett. Ent. Zeit., 1861: 31-42.

Huebner, J. [1825]. Verzeichniss bekannter Schmettlinge (sic), (27). Augsburg. Inoue, H. (1954). Check list of the Lepidoptera of Japan, Part 1. Tokyo.

Issiki, S. (1932). in Iconographia Insectorum Japonicorum (in Japanese). Tokyo. (1950). in Iconographia Insectorum Japonicorum, (ed. 2) (in Japanese). Tokyo.

(1957). in Icones Heterocerorum Japonicorum in Coloribus Naturalibus, $1_{-}^{-}$(in Japanese). Osaka. 
Jäckh, V. E. (1955). Schutzvorrichtung zum Bau des Verpuppungskokons bei Arten der Gattung Bucculatrix Z. und Lyonetia Hb. (Lep., Lyonetiidae). Zeit. Wiener Ent. Ges., 40: 118-121, 4 pls.

Kemner, N. A. (1926). Clerks minerarmal (Lyonetia clerckella L.). Medd. Centr. Anst. fösöks Ent. Avdeln., No. 49: 1-59.

Klots, A. B. (1956). in Tuxen, taxonomist's glossary of genitalia in insects. Lepidoptera. Copenhagen.

Kobayashi, G. (1923). [On the leaf miner of Eurya japonica Thunb.]. Byōchūgai Zasshi, 10 (12) : 554-555 (in Japanese).

Kumata, T. (1963). Synonymic notes on a gracillariid moth. Insecta Matsumurana, 25 (2): 136.

Kuroko, H. (1957). Enumeratio Insectorum Montis Hikosan I. Lepidoptera.

-- -- ---- (1959). Enumeratio Insectorum Montis Hikosan I. Lepidoptera, Supplementum 1 .

--- (1961). A study on Lyonetiaanthemopa Meyrick from Japan (Lepidoptera, Lyonetiidae). Pub., Ent. Lab., Univ., Osaka Pref., No. 6: 17-22, pl. 2, pl. 17, ff. D-F.

Kuwana, I. \& N. Takachiho (1911). Rep. Imp. Agr. Exp. Stat., Tokyo, No. 38 (in Japanese).

Lhomme, L. (1936). Catalogue des Lépidoptères de France et de Belgique, Tineina.

McDunnough, J. (1939). Check list of the Lepidoptera of Canada and the United States of America. Part. 2. Mem. S. California Acad. Sci., 2 (1): 1-171.

Matsumura, S. (1906). Nippon Gaichū Mokuroku (in Japanese).

- (1907). Konchū Bunruigaku, 1 (in Japanese).

(1610). Dainihon Gaichū Zensho, 1 (in Japanese).

-... (1920). Gaichū Zensho, 1 (in Japanese).

(1931). 6000 Illustrated insects of Japan-Empire (in Japanese). Tokyo.

(1932). New genera and new species described in " 6000 illustrated insects of Japan-empire ". Insecta Matsumurana, 6 (4): 199-200.

Meyrick, E. (1881). Descriptions of Australian Micro-Lepidoptera. Proc.Linn. Soc. N. S. Wales, 5: 132-182, 204-207.

_._- (1886). Descriptions of Lepidoptera from the South Pacific. Trans. Ent. Soc. London, 1886: 189-296.

--_ (1893). Descriptions of Australian Micro-Lepidoptera. Proc. Linn. Soc.

N. S. Wales, 7: 599-604.

(1895). A handbook of British Lepidoptera. London.

-... (1912). Descriptions of Indian Micro-Lepidoptera. Journ. Bombay Nat. Hist. Soc., 21: 108-109.

(1912-37). Exotic Microlepidoptera, 1-5. London.

- (1918). Descriptions of South African Micro-Lepidoptera. Ann. Transvaal Mus., 6: 7-59.

(1929). A revised handbook of British Lepidoptera. London.

Miyoshi, K. (1923). [On the leaf miner of Eurya japonica Thunb.]. Byōchūgai Zasshi, 10 (9/10): 493-497 (in Japanese). 
Needham, J. G., S. W. Forst \& B. H. Tothill (1928). Leaf-mining Insects. Baltimore.

Netley, F. B. (1949). The Leucoptera leaf miners of coffee on Kilimanjaro. I.Leucoptera coffeella, Guér. Bull. ent. Res., 39: 399-416.

(1956). The Leucoptera leaf miners of coffee on Kilimanjaro. II.Leucopteracaffeina Washbn. Bull ent. Res., 46: 899-912.

Ohwi, J. (1953). Flora of Japan (in Japanese). Tokyo.

Okano, M. (1959). in Iconographia Insectorum Japonicorum Colore Naturali Edita, 1 (Lepidoptera) (in Japanese). Tokyo.

Orstadius, E. (1918). Ytterligare anteckningar om f järilar, huvudsakligen småfjärilar, i Kronobergs län. Ent. Tidsckr., 39: 69-78.

Paulian, R. \& P. Viette (1955). Essai d'un catalogue biologique des Lépidoptères Hétérocères de Tananarive. Mém.l'Inst. Sci. Madagascar, Ser. E. 6: 141-272.

Pierce, F. N. \& J. W. Metcalfe (1935). The genitalia of the Tineid families of the Lepidoptera of the British Islands. Oundle.

Rebel, H. (1901). in Staudinger-Rebel, Catalog der Lepidopteren des palaearctischen Faunengebietes, 2. Berlin.

Reutti, C. (1853). Übersicht der Lepidopteren-Fauna des Grossherzogthum's Baden. Beiträge zur Rheinischen Naturgeschichte, herausgegeben von der Gesellschaft zur Befdrderung der Naturwissenschaften zu Freigurg im Breisgau, 3 Heft.: 208.

Sasaki, C. (1903). [The leaf miners of the fruit-trees]. Dobutugaku Zasshi, no. 181: 181-383 (in Japanese).

(1905). Kaju Gaichū Hen, 234 pp. (in Japanese).

Skala, V. H. (1951). Minen aus Steiermark, gesammelt von Fritz Hoffmann. Zeit. Wiener Ent. Ges., 36: 119-126.

Snellen, P. C. T. (1882). De Vlinders van Nederland. Microlepidoptera, 2. Leiden.

Sorhagen, L. (1885). Aus meinen entomologischen Tagebuche. Berliner ent. Zeit., $29: 81-108$.

Spuler, A. (1910). Die Schmetterlings Europas, 2. Stuttgart.

Stainton, H. T. (1854). Insecta Britanica. Lepidoptera: Tineina. London.

-- (1855). The natural history of the Tineina, 1. London.

(1862). The natural history of the Tineina, 7. London.

(1869). The Tineina of Southern Europe. London.

Stringer, H. (1930). On new species of Microlepidoptera. Ann. Mag. Nat. Hist., (10) $6: 415-422$.

Trägårdh, I. (1910). Clercks minerarmal (Lyonetia clerckella L.). Ent. Tidsck., $1910: 266-271$.

(1913). Contributions towards the comparative morphology of the trophi of the Lepidopterous leaf-miners. Ark. Zool., 8(9): 1-48.

Vari, L. (1955). South African Lepidoptera I. Descriptions of new leafmining Tineina. Ann. Transvaal Mus., 22 (3): 331-341. 
Viette, P. (1949). Catalogue of the Heterocerous Lepidoptera from French Oceania. Pacific Science, 3 (4): 315-337.

- (1951). Quelques Microlépidoptères de Madagascar. Mém.l'Inst. Sci. Madagascar, Ser. A. 5 (2): 337-346.

-- (1954). Nouveaux Tineoidea (s. 1.) de Madagascar. (Lep.) Ann. Soc. Ent. France, 123: 75-114.

Walsingham, L. (1882). Notes on Tineidae of North America. Trans. Amer. Ent. Soc., 10: 165-204.

(1891). African Micro-Lepidoptera. Trans. Ent. Soc. London, 1891: 63 to 132,5 pls.

(1897). Revision of the West-Indian Micro-Lepidoptera, with descriptions of new species. Proc.Zool.Soc. London, 1897: 54-183.

-- ---- (1907). Microlepidoptera of Tenerife. Proc. 2001. Soc. London, 1907 : 911-1034, 2 pls.

-...... (1907). Fauna Hawaiiensis, 1. Cambridge.

Wolff, N. J. (1953). Sommer fugle larver importeret med bananer. Ent. Medd., $26: 512-521$.

Woo, W. (1961). A new record of two species of fruit tree pest from North China. Acta Ent. Sinica, 10 (4/6): 395-400.

Zeller,P. C. (1848). Die Gattungen der mit Augendeckeln verschenen blattminirenden Schaben beschrieben. Linnaea. Entom., 3: 248-344.1 pl. 


\title{
Explanation of Plates
}

The scale of each figure shows $0.2 \mathrm{~mm}$. in length, except the male genitalia of Lyontia the scale of which shows $0.1 \mathrm{~mm}$.

Explanation of symbols applied to male genitalia Ae: Aedoeagus, Ap: Process on 8th sternite, Gn: Gnathos, Sc: Saccus, Su : Superuncus, Va: Valva, Ta: Tuba analis, T8: 8th tergite, S7: 7th sternite.

\author{
Plate 1 \\ Right forewings \\ 1. Lyonetia (Lyonetia) clerkella (Linnaeus) \\ 2. Lyonetia (Lyonetia) bakuchia sp. nov. \\ 3. Lyonetia (Lyonetia) yasudai sp. nov. \\ 4a. Lyonetia (Lyonetia) anthemopa Meyrick, aestival form. \\ tb. Ditto, autumnal form. \\ 5a. Lyonetia (Lyonetia)prunifoliella malinella (Matsumura), f. ringoniella \\ Matsumura. \\ 5b. Ditto, f. malinella Matsumura. \\ 6a. Lyonetia (Lyonetia) ledi Wocke \\ 6b. Ditto, northern race. \\ 7. Lyonetia (Lyone tia) boehmeriella sp. nov. \\ 8a. Lyonctia (Lyonetiola) euryella sp. nov. \\ 8b. Ditto, southern race. \\ 9a. Lyonetia (Lyonetiola) myricella sp. nov., aestival form. \\ 9b. Ditto, autumnal form. \\ 10a. Lyonetia (Lyonetiola) castaneclla sp. nov., aestival form. \\ 10b. Ditto, autumnal form. \\ 11. Proleucoptera celastrella sp. nov. \\ 12. Proleucoptera smilactis sp. nov. \\ 13. Paraleucoptera sinuella (Reutti) \\ 14. Leucoptera pucrariella sp. nov. \\ 15a. Microthauma glycinella sp. nov., aestival form. \\ 15b. Ditto, autumnal form.
}

\author{
Plate 2 \\ Lateral view of heads of genera \\ (Apical half of eyecap is removed in some genera.)
}

16. Bcdellia Stainton (Bedellia somnulentella Zeller).

17. Buccula trix Zeller (Buccula trix pyrivorella sp. nov.).

18. Lyonetia Huebner (Lyonetia clerkella Linnaeus).

19. Microthauma Walsingham (Microthauma glycinella sp. nov.).

20. Proleucoptera Busck (Proleucoptera smilactis sp. nov.).

21. Paraleucoptera Heinrich (Paraleucoptera sinuella Reutti).

22. Leucoptera Huebner (Leucoptera spartifoliella Huebner). 
Wing venation

23. Bucculatrix exedra Meyrick

24. Bedellia somnulentella (Zeller)

25. Lyonetia (Lyonetiola) castaneella sp. nov.

26. Lyonetia (Lyonetia) clerkella (Linnaeus)

27. Lyonetia (Lyonetia) anthemopa Meyrick

28. Microthauma glycinella sp. nov.

29. Proleucoptera smilactis $s p$. nov.

30. Proleucopteracelastrella sp. nov.

31. Paraleucoptera sinuella (Reutti)

32. Leucoptera puerariella sp. nov.

33. Leucoptera spartifoliella (Huebner)

Plates 5-10

Male genitalia

34. Bucculatrix pyrivorella sp. nov.

35. Bucculatrix crataegi (Zeller)

36. Bucculatrix exedra Meyrick

37. Bedellia somnulentella (Zeller), bred from Ipomoea purpurea Lam.

38. Lyonetia (Lyonetiola) castaneella sp. nov.

a. Lateral view of male genitalia.

b. Sclerotized ridge on 8th tergite and superuncus.

39. Lyonetia (Lyonetiola) myricella sp. nov.

a. Lateral view of male genitalia.

b. Sclerotized ridge on 8th tergite and superuncus.

c. Aedoeagus, lateral view.

40. Lyonetia (Lyonetiola) euryella sp. nov.

a. Lateral view of male genitalia.

b. Valvae, dorsal view.

c. Sclerotized ridge on 8th tergite and superuncus.

d. Aedoeagus, lateral view.

41. Lyonetia (Lyonetia) prunifoliellamalinella (Matsumura)

a. Lateral view of male genitalia.

b. Dissected genital ring, showing gnathos and saccus.

c. Sclerotized ridge on 8th tergite and snperuncus.

42. Lyonetia (Lyonetia) boehmeriella sp. nov.

a. Lateral view of male genitalia.

b. Dissected genital ring, showing gnathos and saccus.

c. Sclerotized ridge on 8th tergite and superuncus.

d. Valva. 
43. Lyonetia (Lyonetia) ledi Wocke

a. Sclerotized ridge on 8th tergite and superuncus.

b. Ventral view of male genitalia, removed aedoeagus.

c. Aedoeagus, lateral view.

44. Lyonetia (Lyonetia) anthemopa Meyrick

a. Sclerotized ridge on 8 th tergite and superuncus.

b. Valvae and aedoeagus, ventral view.

c. Dissected genital ring, showing gnathos and saccus.

45. Lyonetia (Lyonetia) yasudai sp. nov.

a. Lateral view of male genitalia.

b. Sclerotized ridge on Sth tergite and superuncus.

46. Lyonetia (Lyonetia) clerkella (Linnaeus)

a. Lateral view of male genitalia.

b. Sclerotized ridge on 8th tergite and superuncus.

c. Dissected genital ring, showing gnathos and saccus.

47. Lyonetia (Lyonetia) bakuchia sp. nov.

a. Lateral view of male genitalia.

b. Sclerotized ridge on 8 th tergite and superuncus.

48. Proleucoptera celastrella $\mathrm{sp}$. nov.

a. Ventral view of male genitalia, removed aedoeagus.

b. Aedoeagus.

c. Posterior edge of 7 th sternite.

49. Proleucoplera oxyphyllella sp. nov.

a. Ventral view of male genitalia, removed aedoeagus.

b. Aedoeagus.

50. Proleucoptera smilactis sp. nov.

a. Male genitalia, ventral view.

b. ditto, lateral view.

c. Eighth abdominal segment and its processes.

51. Paraleucoplera sinuella (Reutti)

a. Appendage on 8th sternite.

b. Male genitalia, ventral view.

\section{Plate 11}

Figs. 52 \& 53, male genitalia

Figs. 54-57, female genitalia

52. Leucoptera puerariella sp. nov.

53. Microthauma glycinella sp. nov.

a. Processes on 8th sternite.

54. Bucculatrix exedra Meyrick

55. Bucculatrix pyrivorella $s p$. nov.

56. Bucculatrix crataegi (Zeller)

57. Bedellia sommulentella (Zeller), bred from Ipomoea purpurea Lam. 


\section{Plates $12-13$ \\ Female genitalia}

58. Lyonefia (Lyonetiola) castaneella sp. nov.

59. Lyonetia (Lyonetiola) myricella sp. nov.

60. Lyonetia (Lyonetiola) euryella sp. nov.

61. Lyonetia (Lyonetia) boehmeriella sp. nov.

62. Lyonetia (Lyonetia) ledi Wocke

a. Apex of ovipositor.

63. Lyolzetia (Lyonetia) prunifoliella malinella (Matsumura)

64. Lyonetia (Lyonetia) clerkella (Huebner)

65. Lyonetia (Lyonetia) bakuchia sp. nov.

66. Lyonetia (Lyonetia) yasudai sp. nov.

67. Lyonetia (Lyonetia) anthemopa Meyrick

68. Microthauma glycinella sp. nov.

69. Proleucoptera smilactis sp. nov.

70. Proleucoptera celastrella sp. nov.

\section{Plate 14}

71. Leaf of Firmiana platanifolia Schott. et Endl. with a serpentine mine made by the early instar larva of Bucculatrix exedra Meyrick.

72. Leaf of Ipomoea Batatas Lam. with linear and polygonal-blotch mines of Bedellia somnulentella (Zeller).

73. Lower aspect of the mine of Bedellia somnulentella (Zeller) on the leaf of Calystegia japonica Choisy. The larva is ejecting the frasses from a hole prepared on the lower side of the mine.

74. Leaf of the Prunus Persica Batsch. with a linear mine of Lyonetia clerkella (Linnaeus) (peach race).

\section{Plate 15}

75. Leaf of Prunus Zippeliana Miq. with 3 linear mines of Lyonetia bakuchia sp. nov.

76. Leaf of Pyracantha crenūrata Roem. with a mine of Lyonetia anthemopa Meyrick.

77. Cocoon of Lyonetia anthemopa Meyrick spun underside of the leaf of Pyracantha angustifolia Schneider.

78. Leaf of Rhododendron mucronulatum Turcz. var. ciliatum with a linear-blotch mine of Lyonetia ledi Wocke. 


\section{Plate 16}

79. Leaf of Boehmeria spicata Thunb. with a blotch mine of Lyonetia boehmeriella sp. nov.

80. Leaf of Eurya japonica Thunb. with a mine of Lyonetia euryella sp. nov.

81. Leaf of Myricarubra Sieb. et Zucc. with a mine of Lyonetia myricella sp. nov.

82. Leaf of Celastrus orbiculatus Thunb. with a blotch mine of Proleucoptera celastrella sp. nov.

\section{Plate 17}

83. Leaf of Euonymus oxyphyllus Miq. with a digitate mine of Proleucoptera oxyphyllella sp. nov.

84. Leaf of Smilax China Linn. with a blotch mine of Proleucoptera smilactis sp. nov. and a cocoon.

85. Leaf of Pueraria lobata Ohwi with a blotch mine of Leucoptera puerariella sp. nov.

86. Leaf of Glycine Max Merrill. with a linear-blotch mine of Microthauma glycinella sp. nov. 


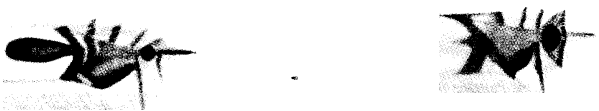

1

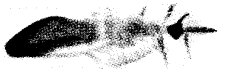

2

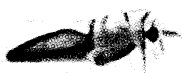

3

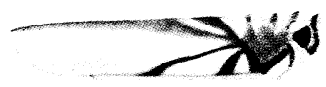

$4 \mathrm{a}$

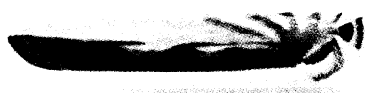

$4 b$

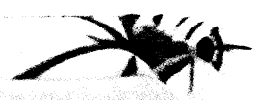

$5 a$
6 a

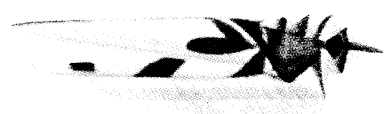

$6 \mathrm{~b}$

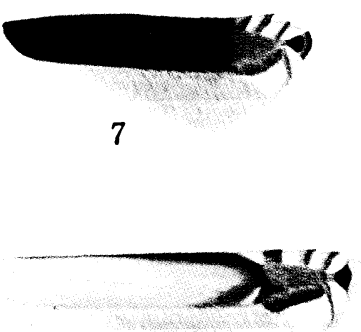

$8 a$

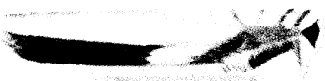

8 b
$10 \mathrm{~b}$

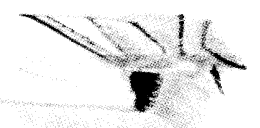

11

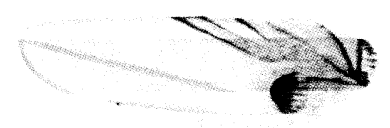

12

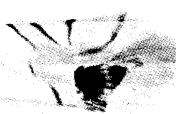

13

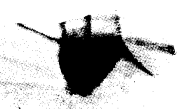

14

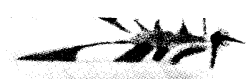

9 a

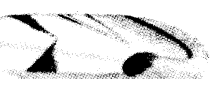

$15 \mathrm{a}$

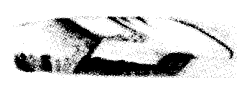

$9 \mathrm{~b}$

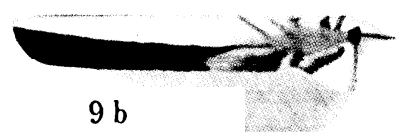

$5 \mathrm{~b}$ 
Plate 2

EsAkIA No. 4, 1964
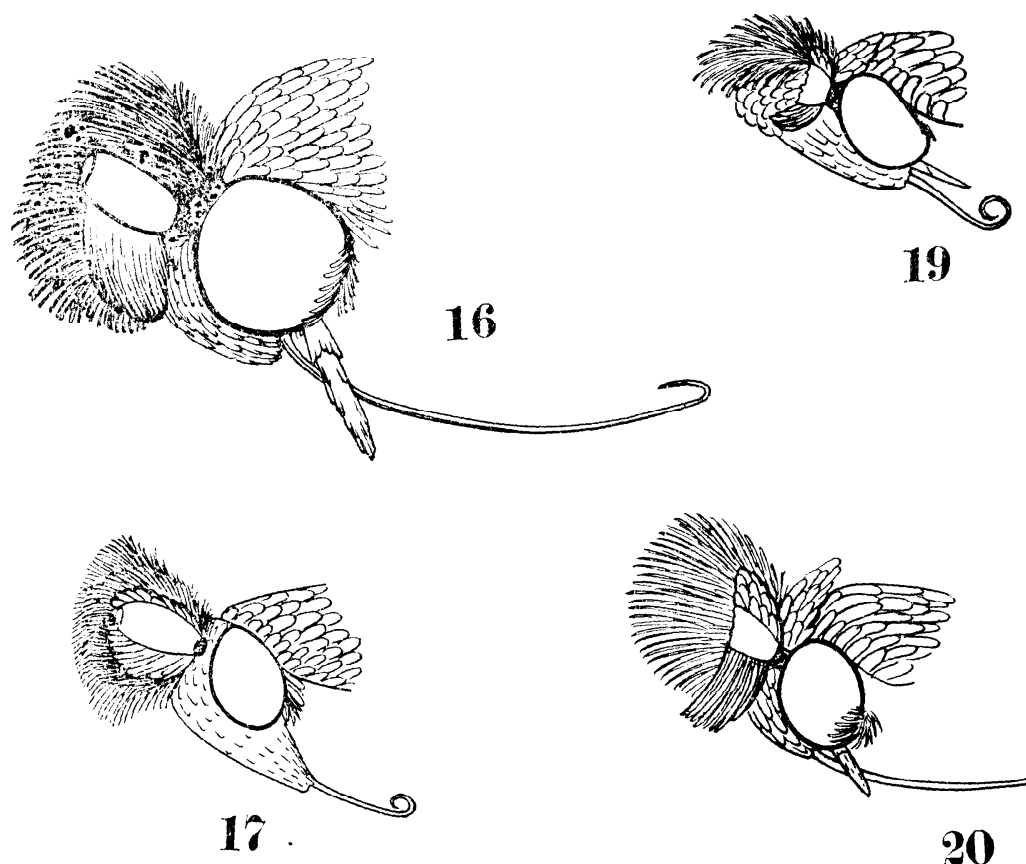

19

\section{6}

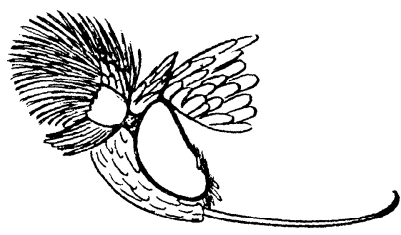

21
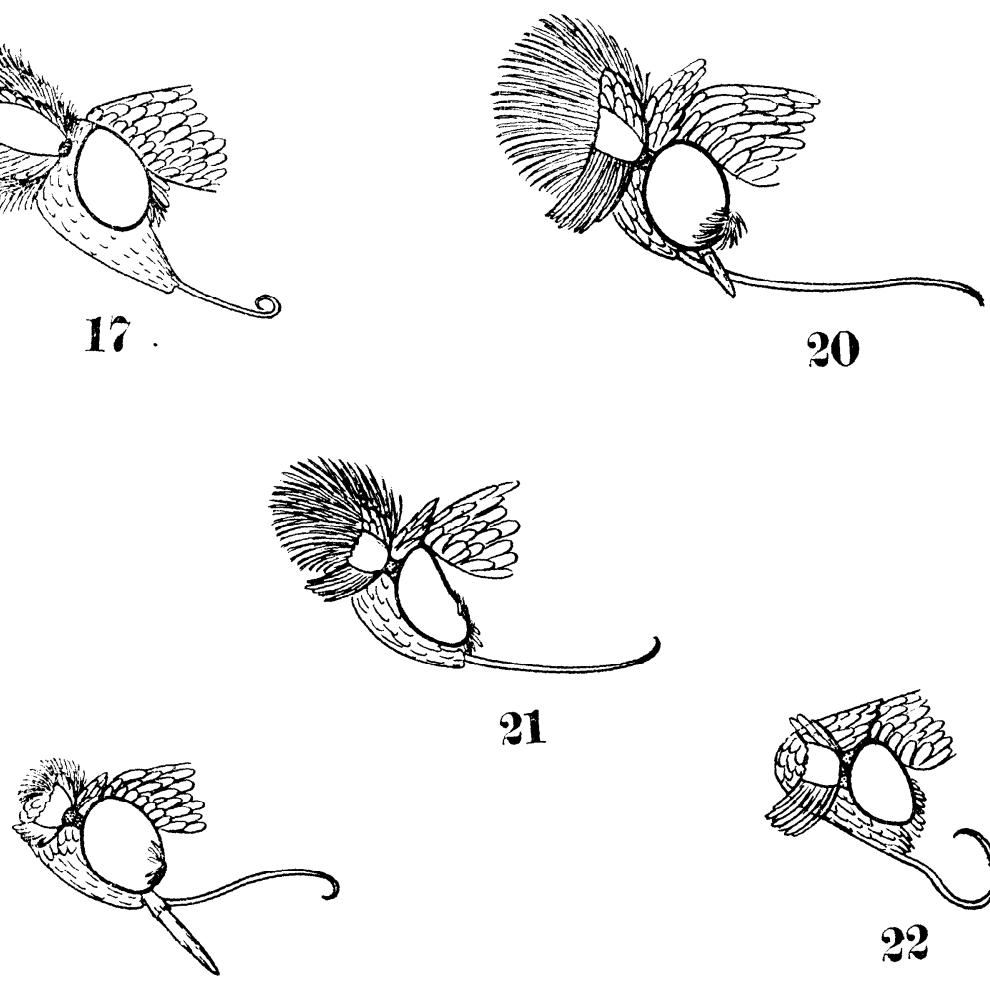

18

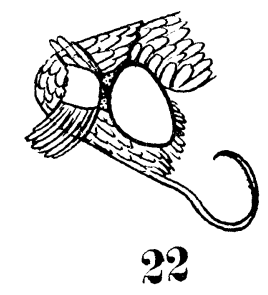



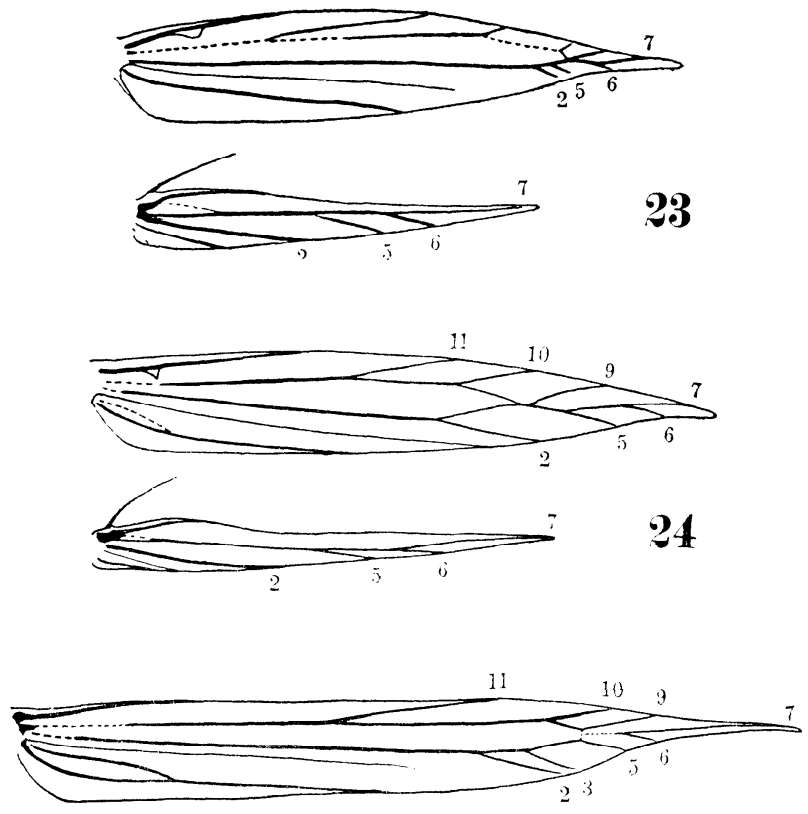

\section{5}

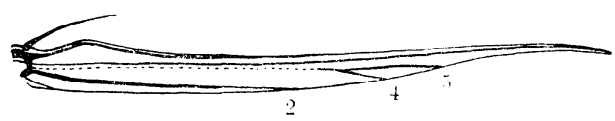

\section{6}

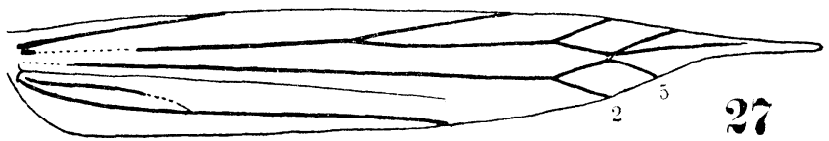



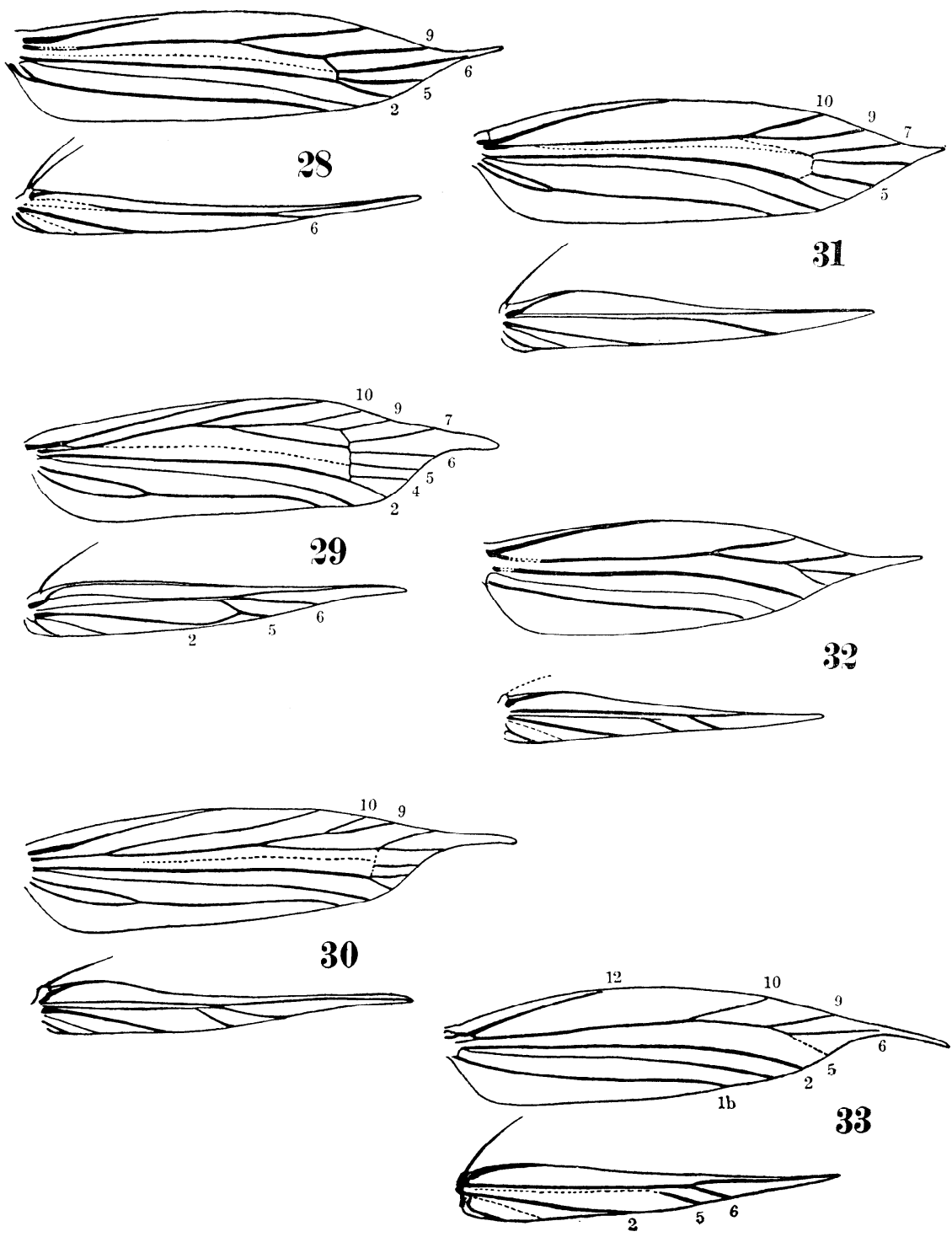

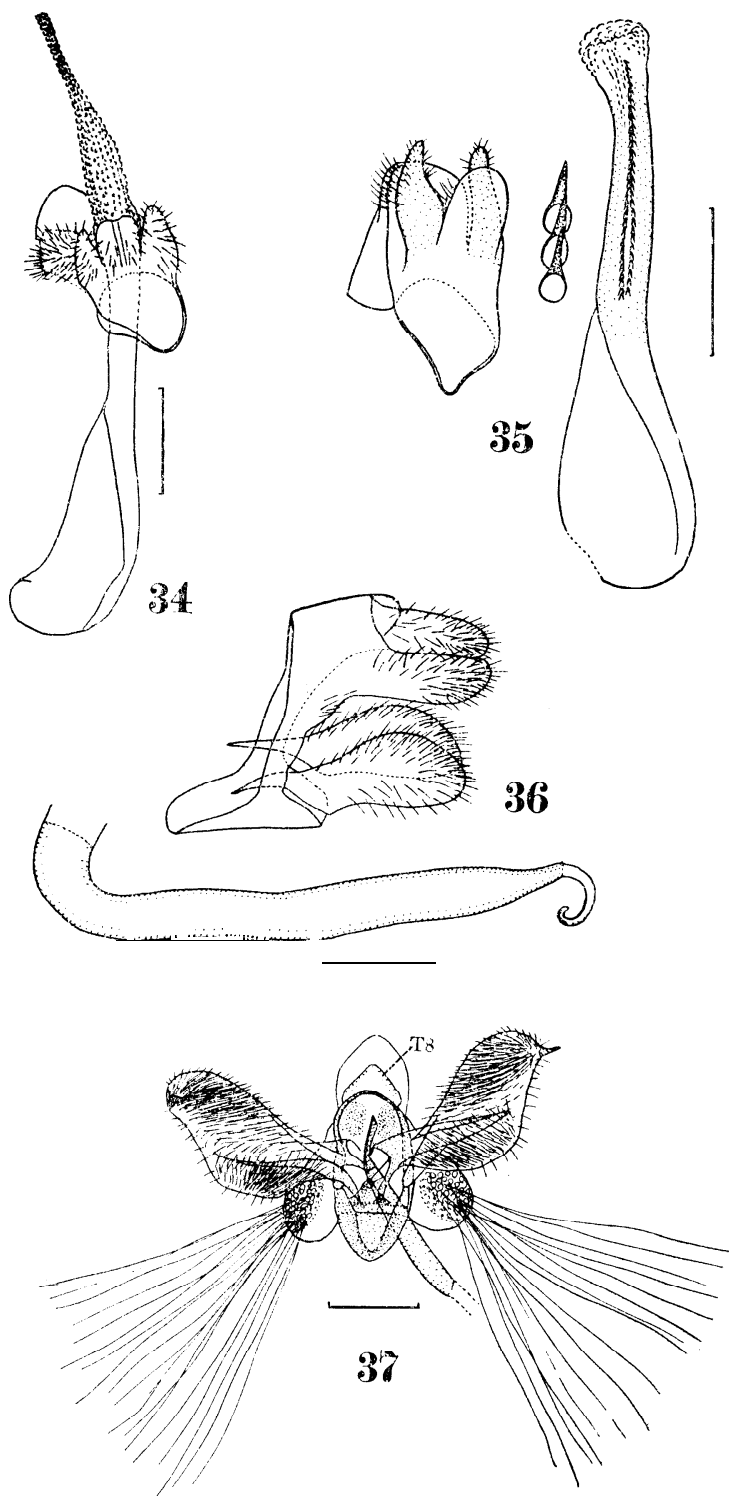

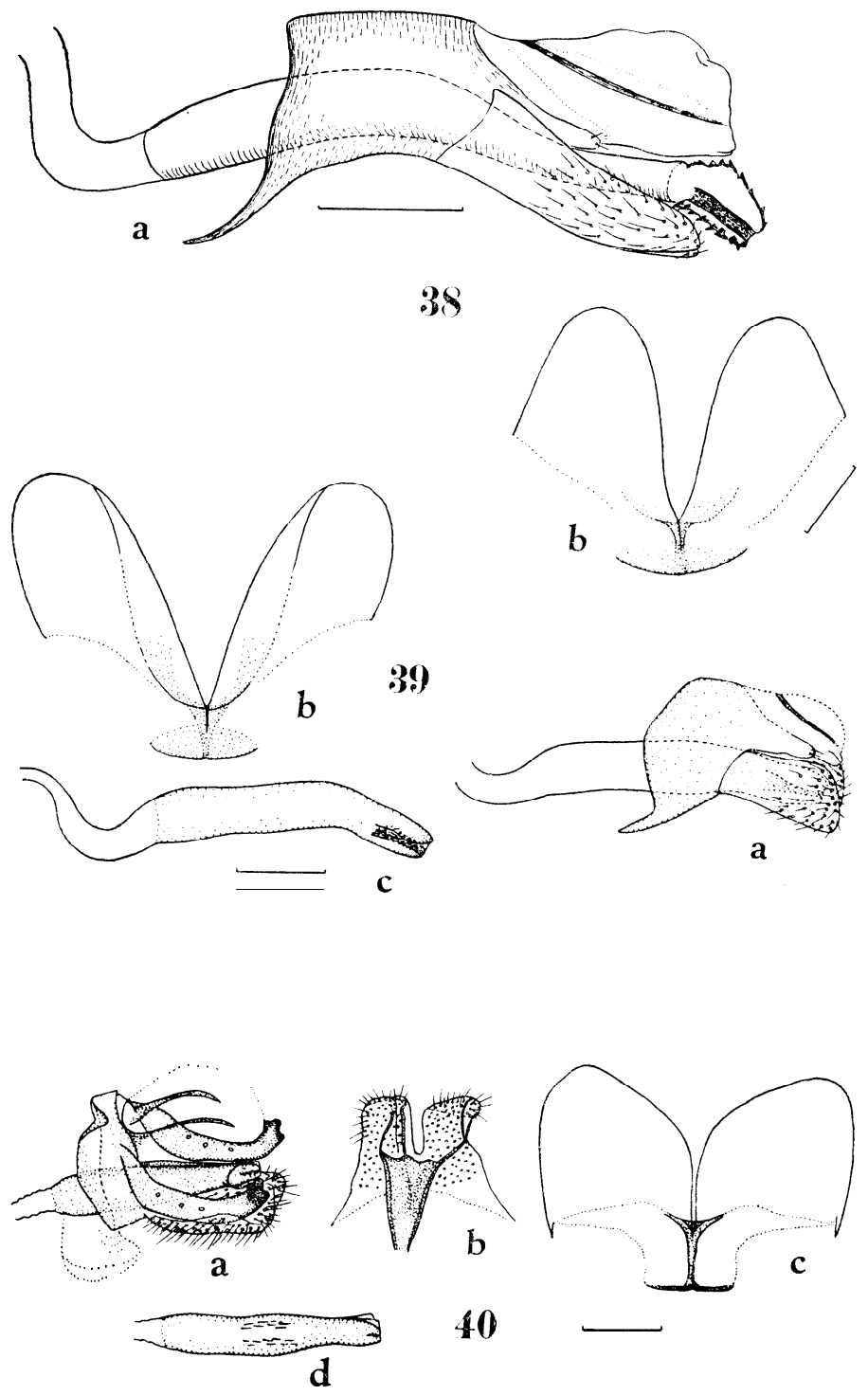

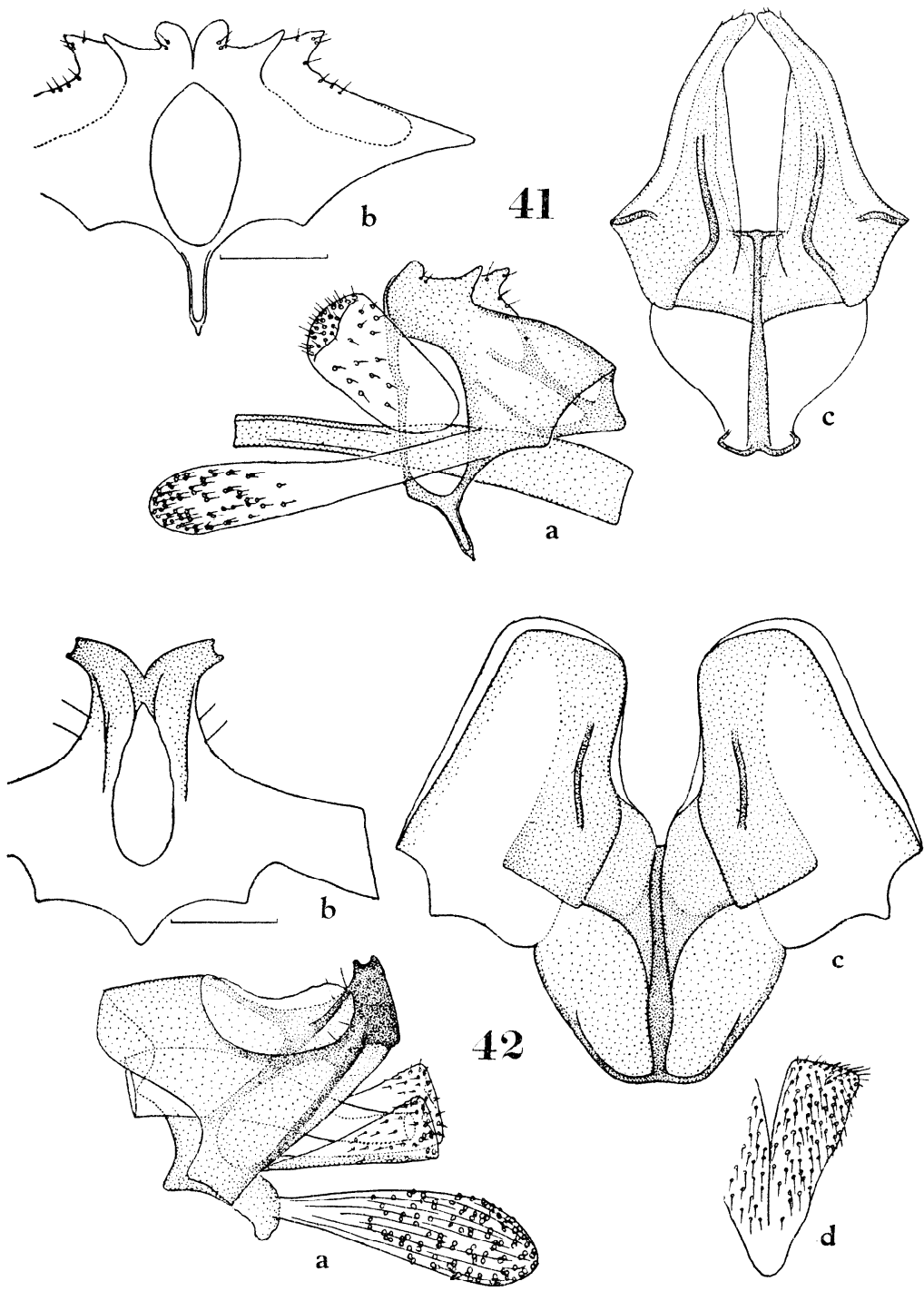

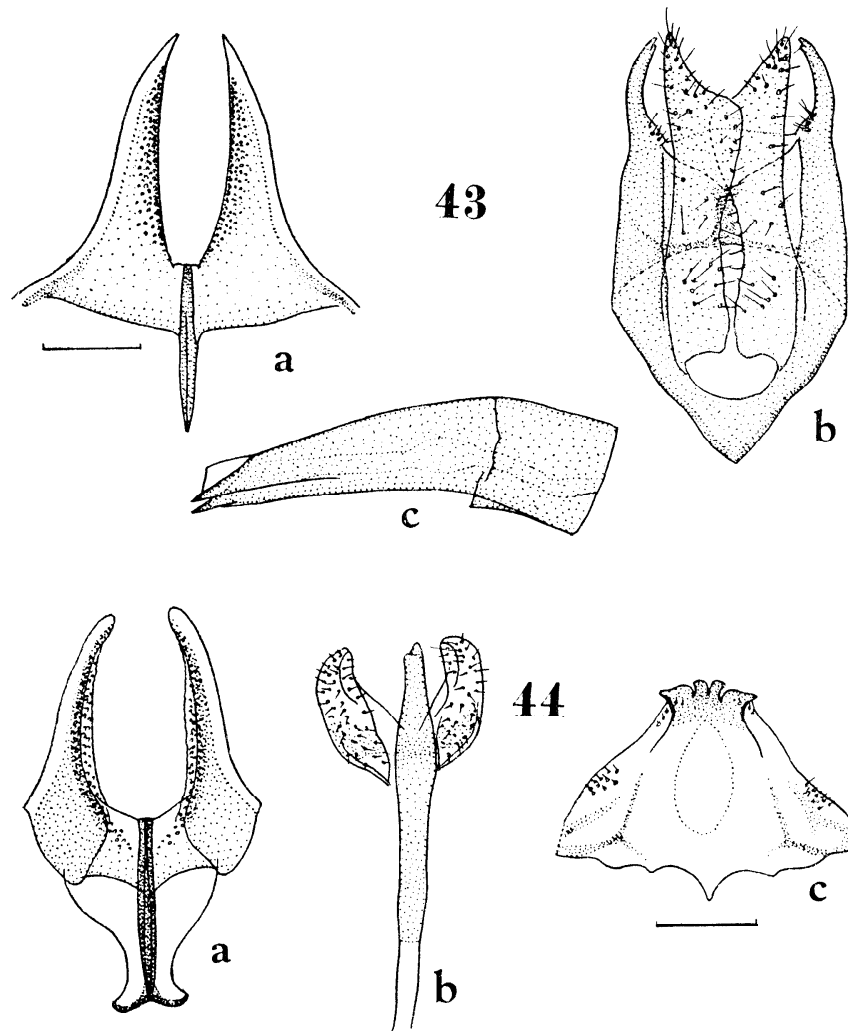

44
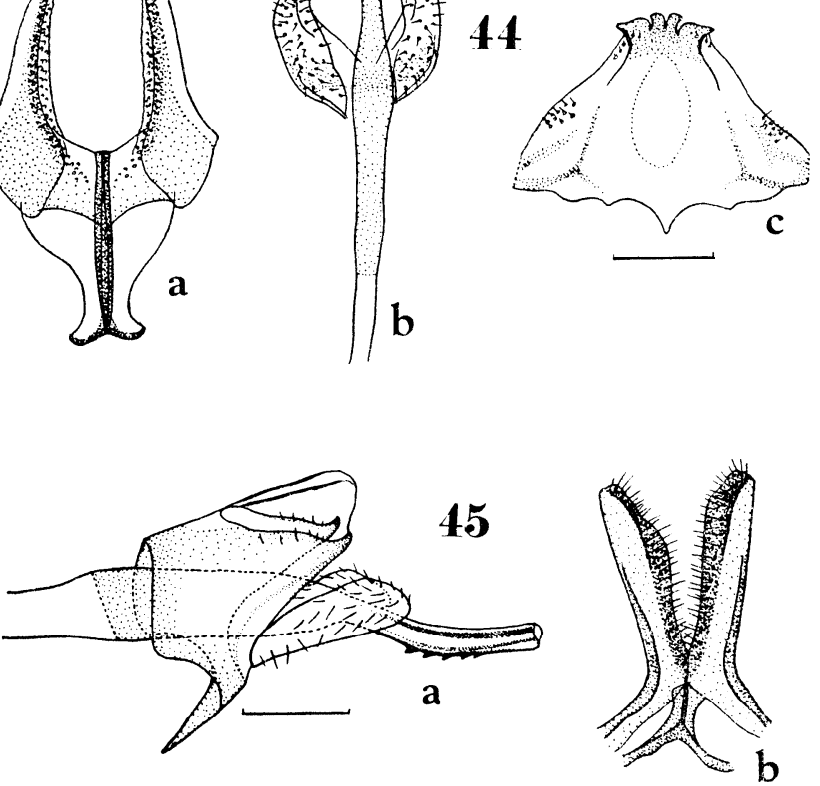

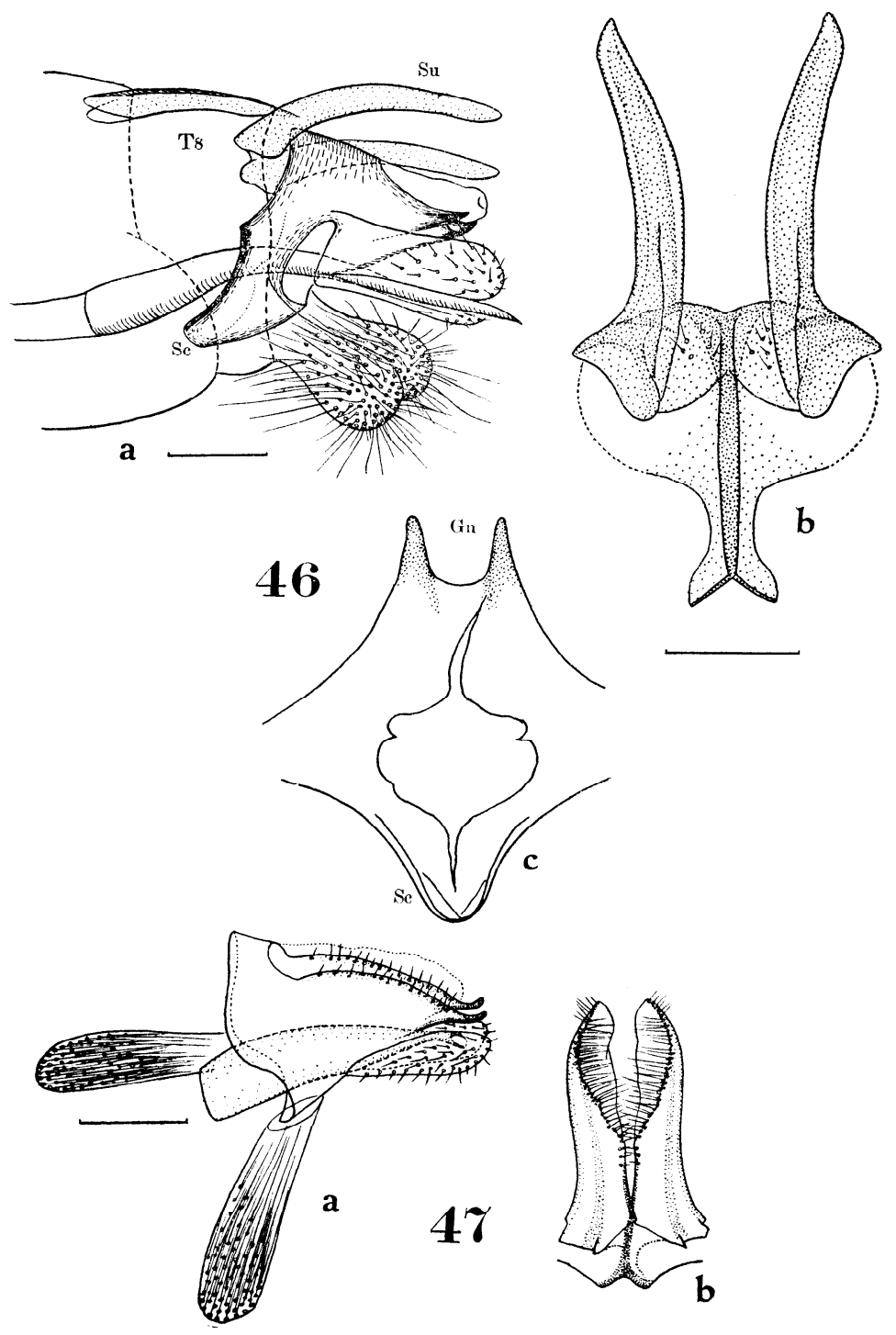

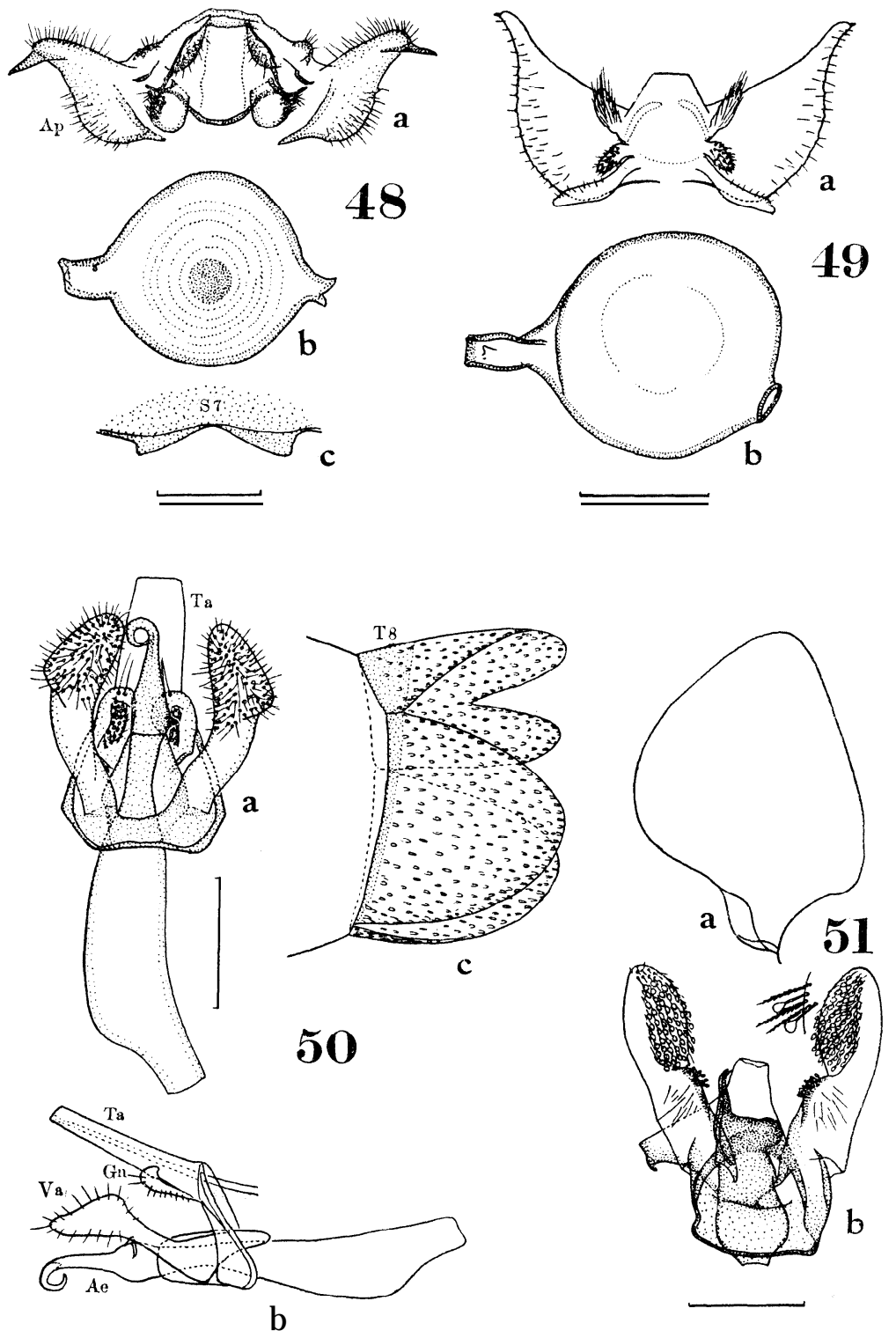


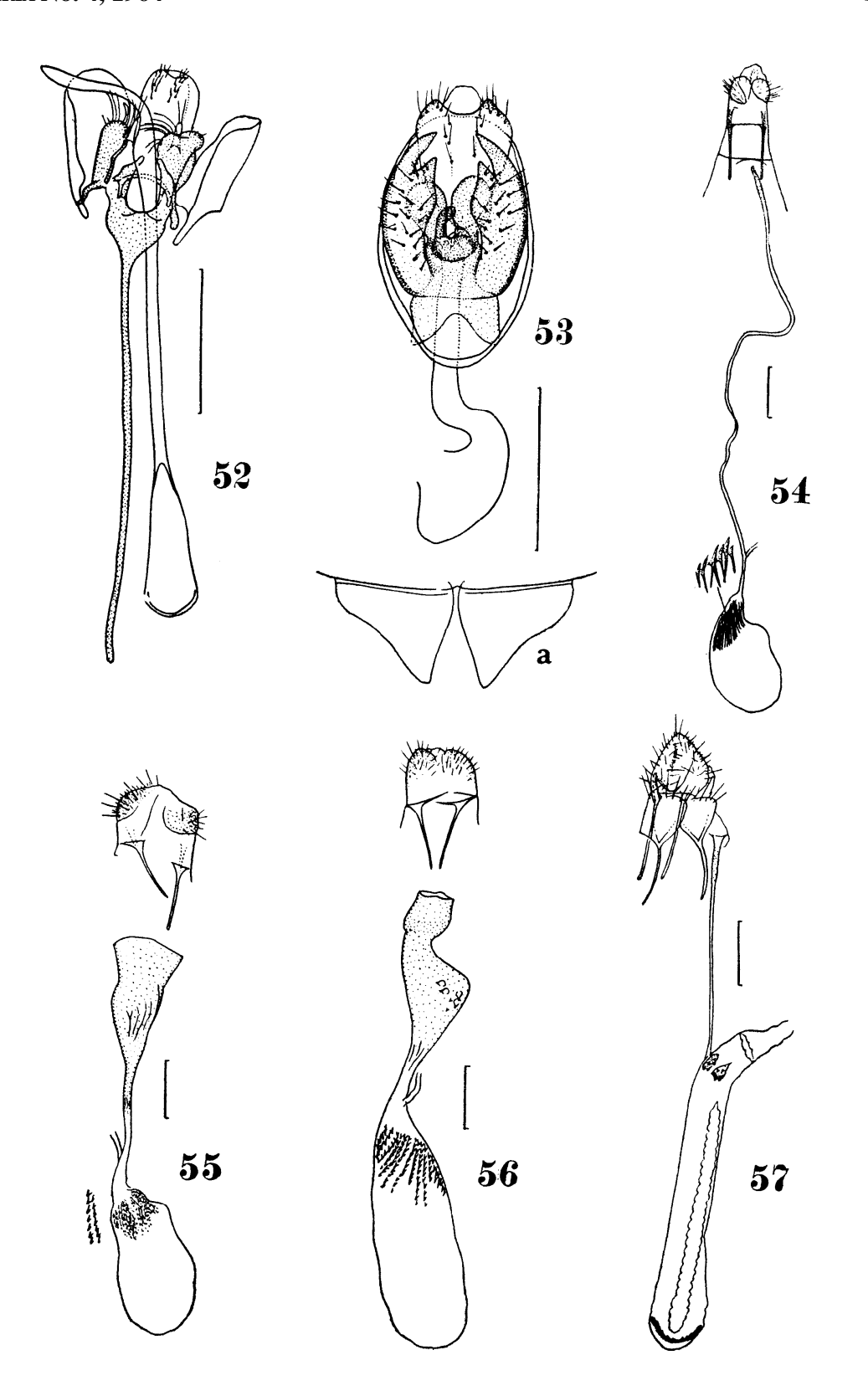



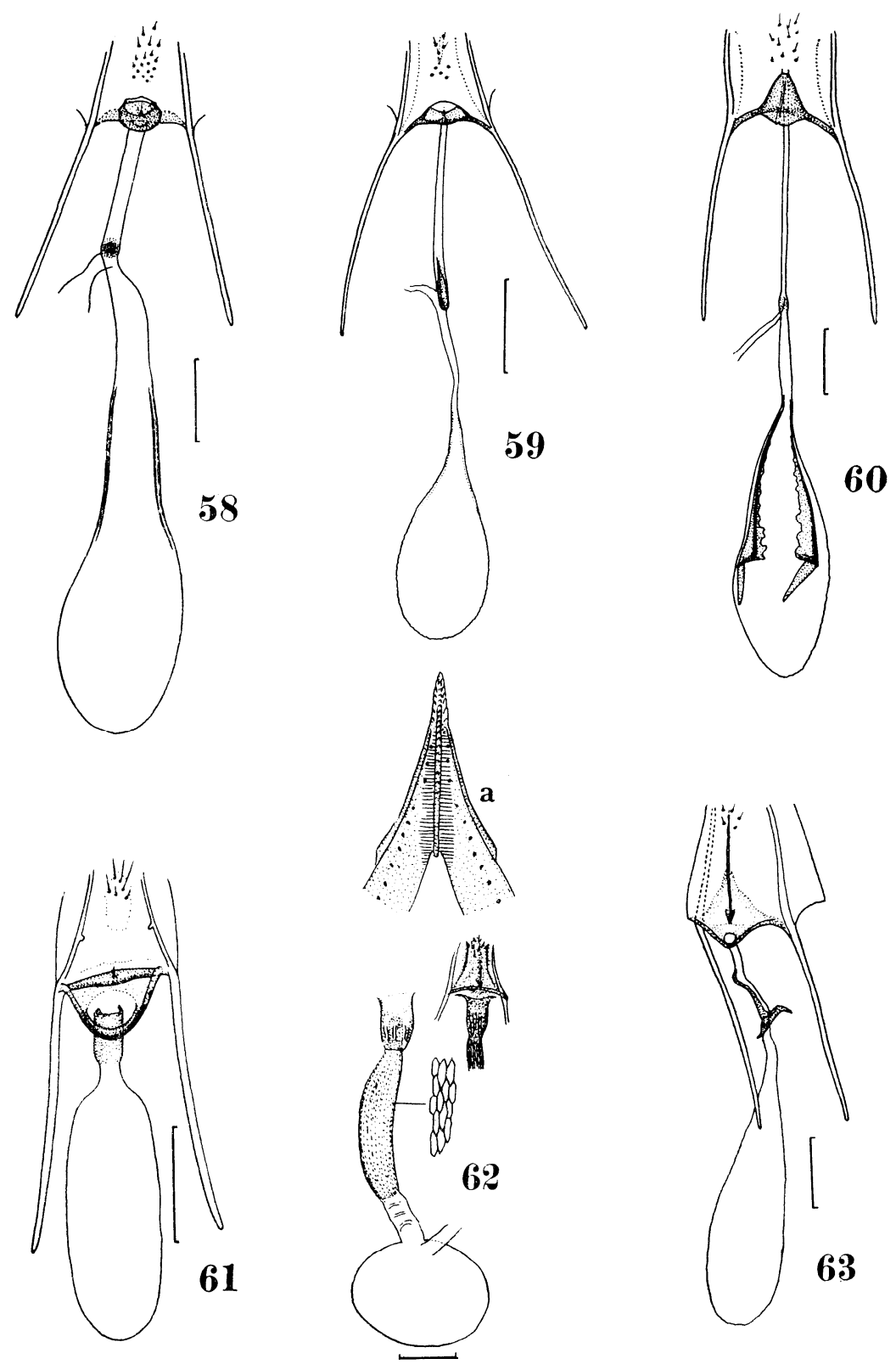
EsAKIA No. 4, 1964

Plate 13
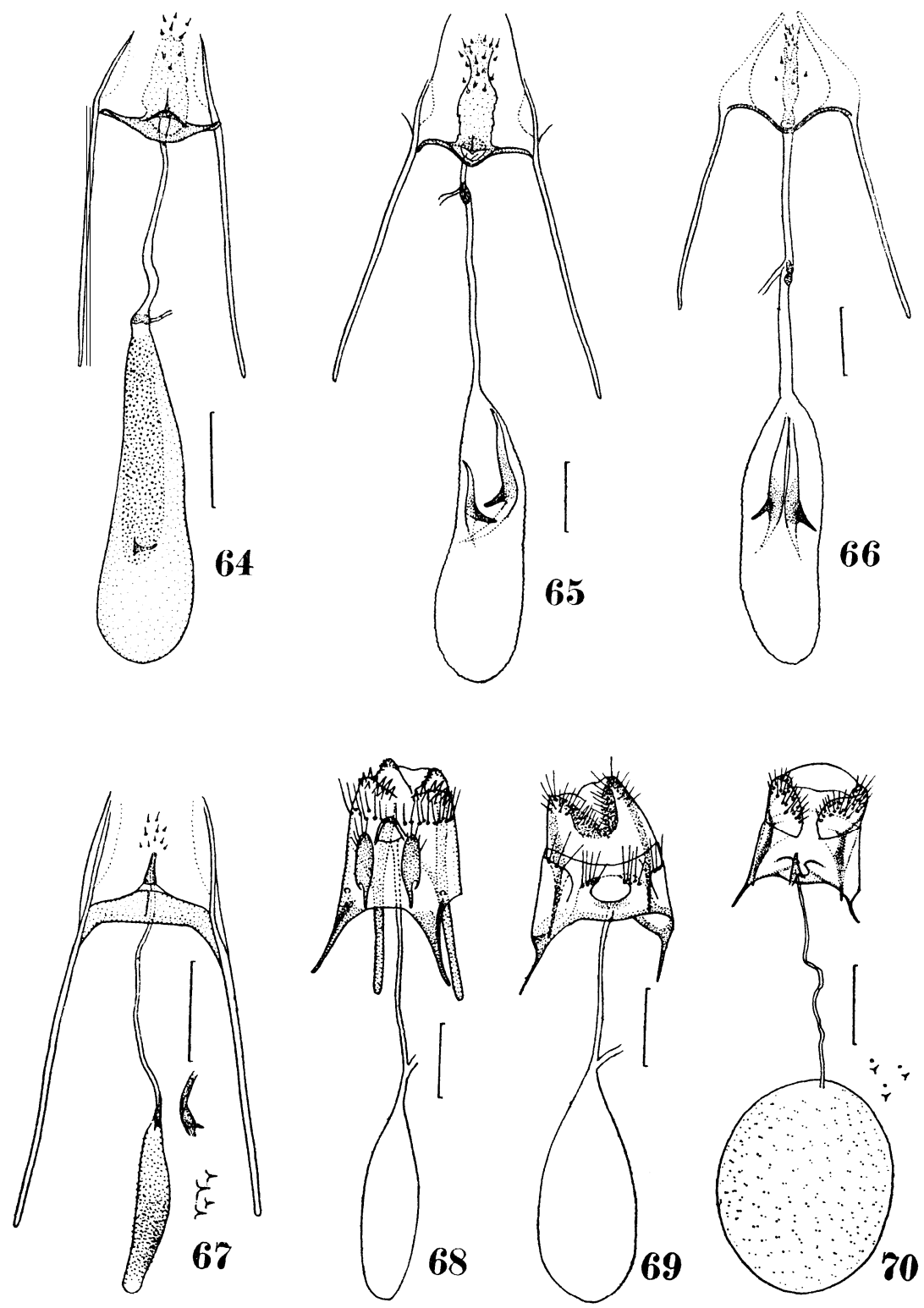

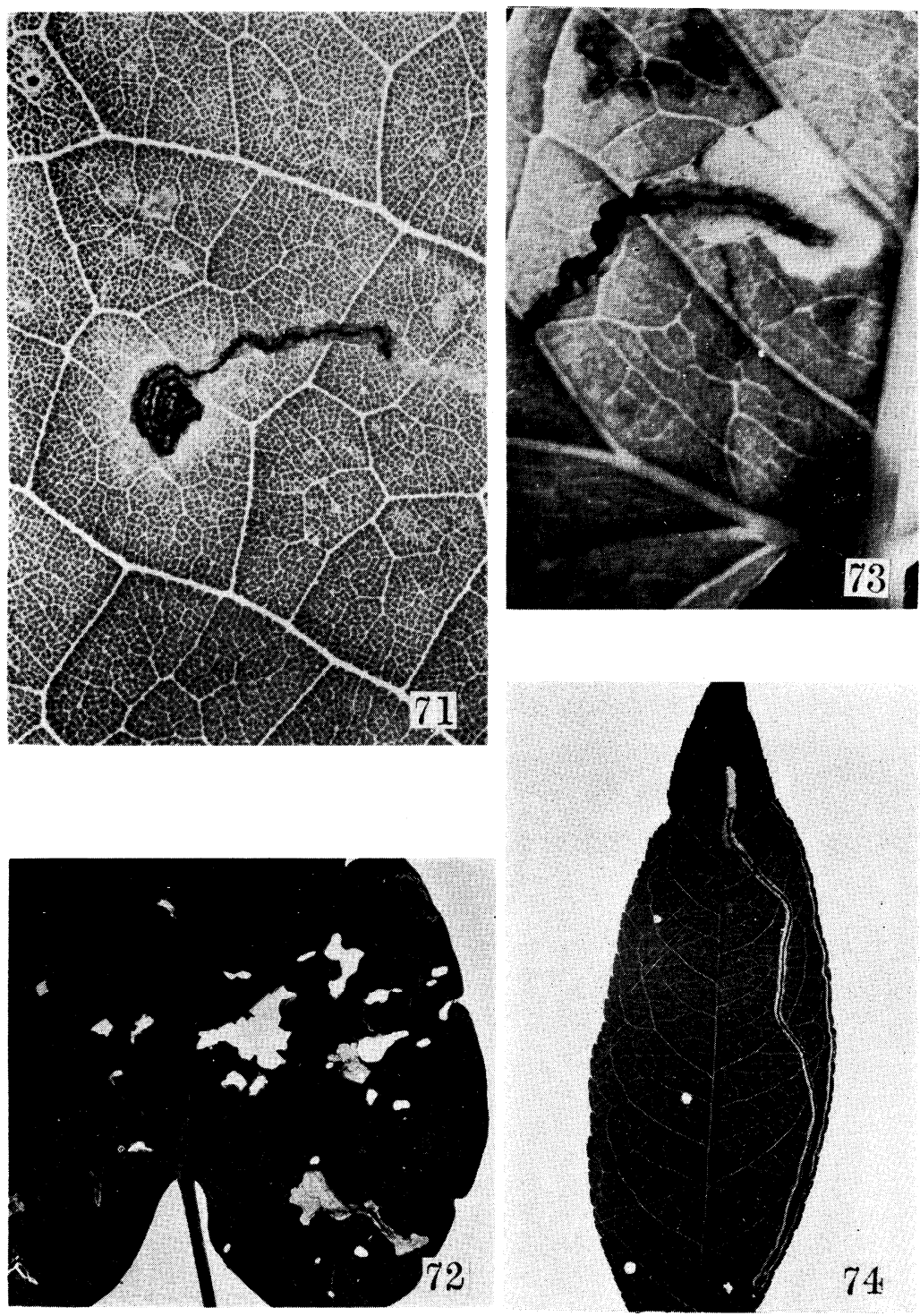

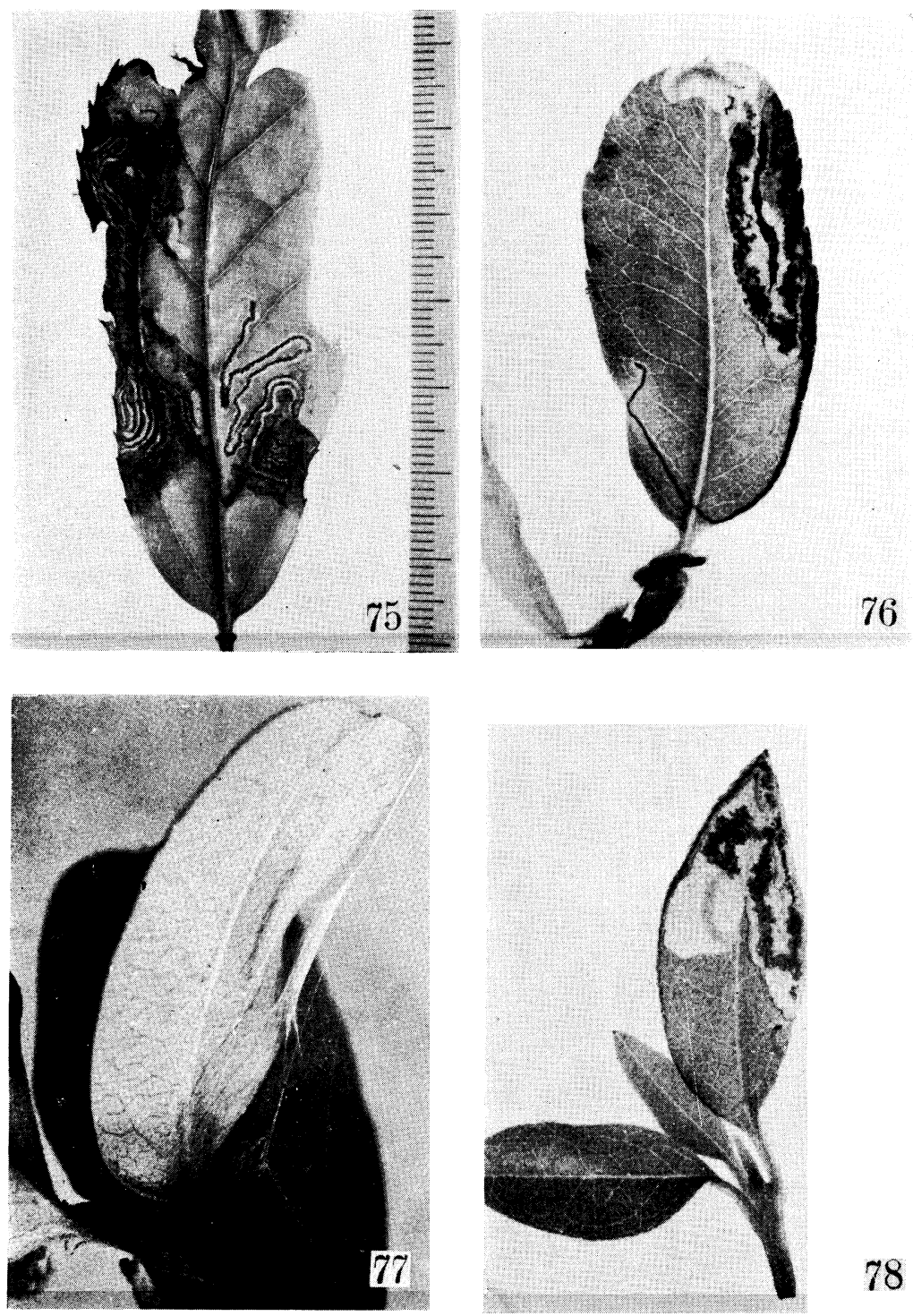

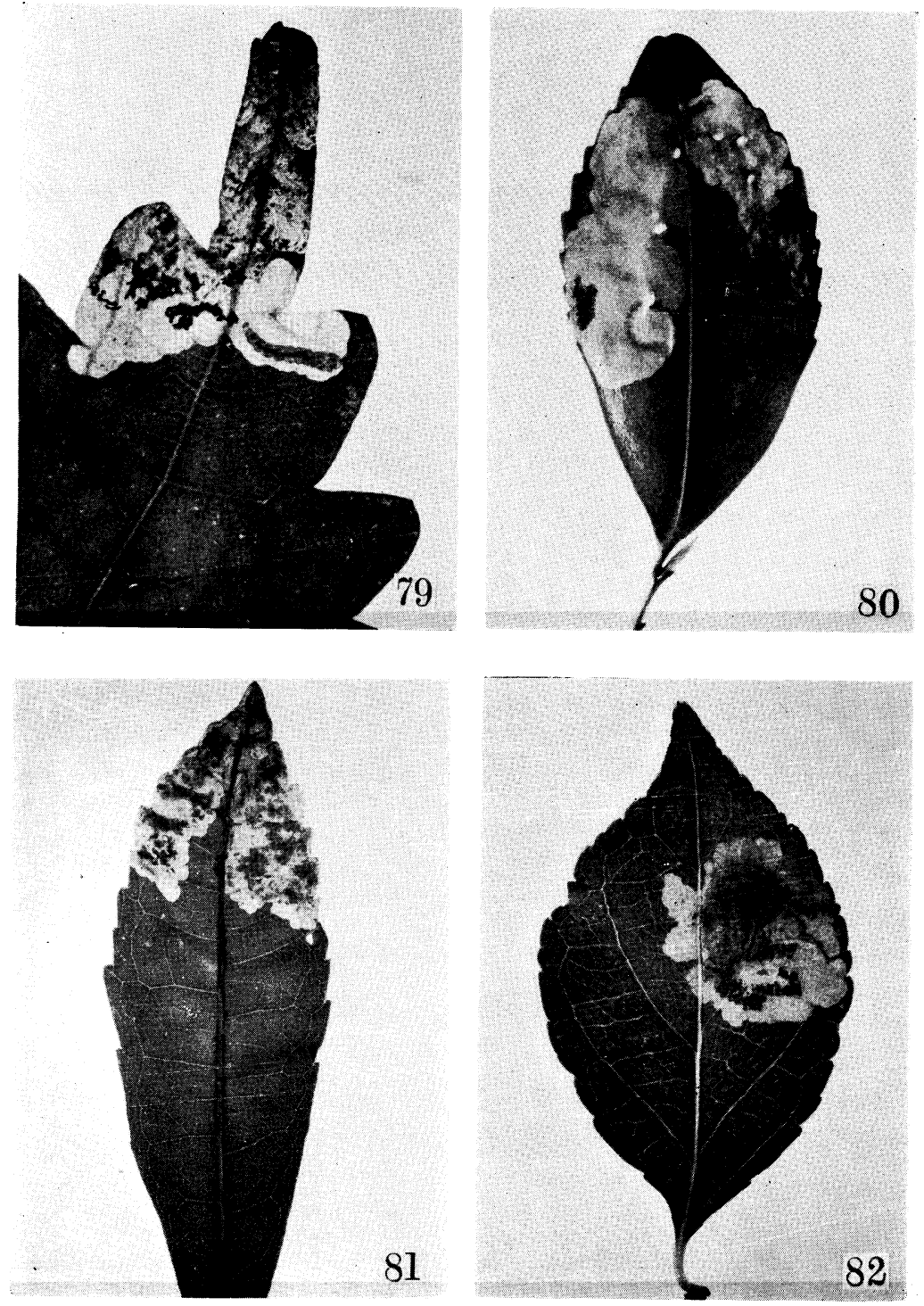

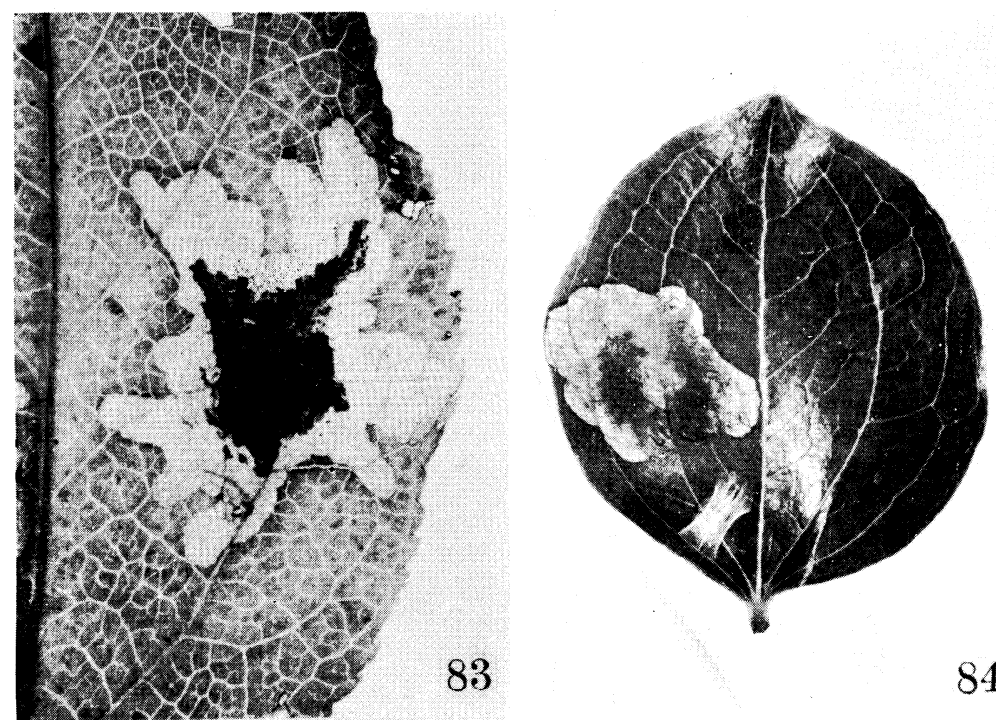

84
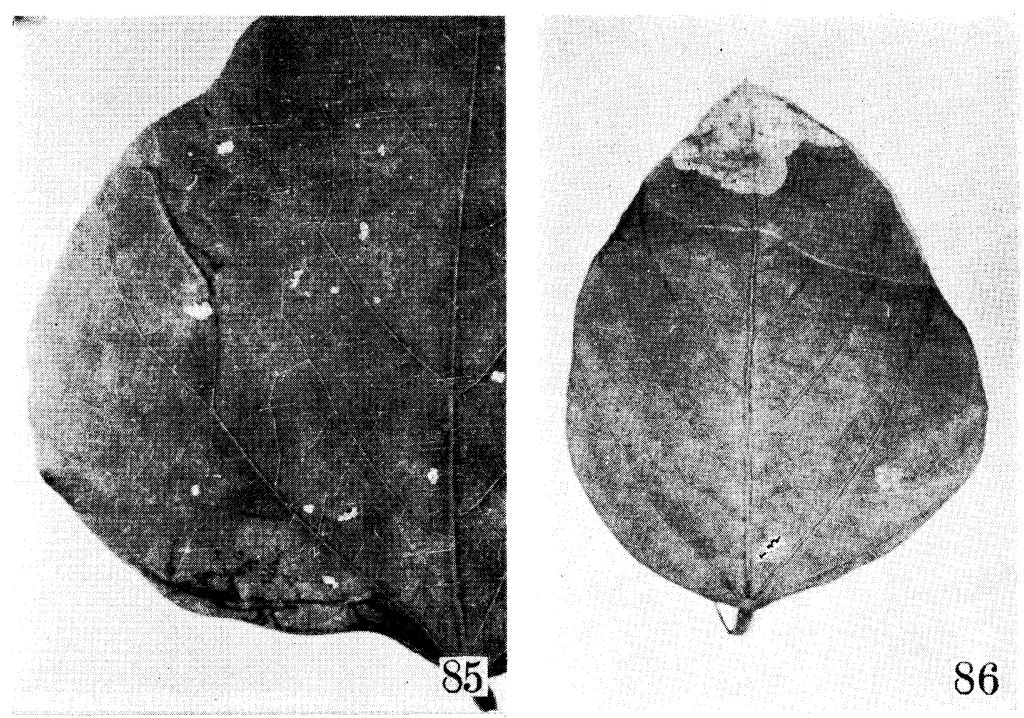